\title{
ESTUDO DO DESEMPENHO MECÂNICO E TÉRMICO DE Compostos de BorRacha NATURAL (NR) DE Diferentes Clones
}

\section{ANA CAROLINA DALL' ANTONIA}

\begin{abstract}
Dissertação apresentada à Área Interunidades em Ciência $e$ Engenharia de Materiais, da Universidade de São Paulo, como parte dos requisitos para a obtenção do título de Mestre em Ciência e Engenharia de Materiais.
\end{abstract}

Orientador: Prof. Dr. Luiz H. Capparelli Mattoso 뜨 USPAFSCISBI

São Carlos - São Paulo 2003

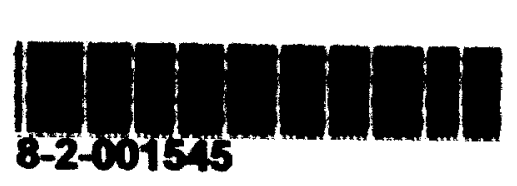


Dall' Antonia, Ana Carolina

"Estudo do Desempenho Mecânico e Térmico de Compostos de Borracha Natural (NR) de Diferentes Clones" I Ana Carolina Dall' Antonia - São Carlos, 2003

Dissertação (Mestrado) - Interunidades Ciência e Engenharia de Materiais da Universidade de São Paulo, 2003 - páginas: 95

Área: Ciência e Engenharia de Materiais

Orientador: Prof. Dr. Luiz H. Capparelli Mattoso

1. Borracha Natural; 2. Clones de Seringueira, 3. Análises Térmicas, 4. Análises Mecânicas.

1. Titulo 
MEMBROS DA COMISSÃO JULGADORA DA DISSERTAÇÃO DE MESTRADO DE ANA CAROLINA DALL ANTONIA, APRESENTADA À ÁREA INTERUNIDADES CIÊNCIA E ENGENHARIA DE MATERIAIS, UNIVERSIDADE DE SÃO PAULO, EM 17/09/2003.

COMISSÃO JULGADORA:

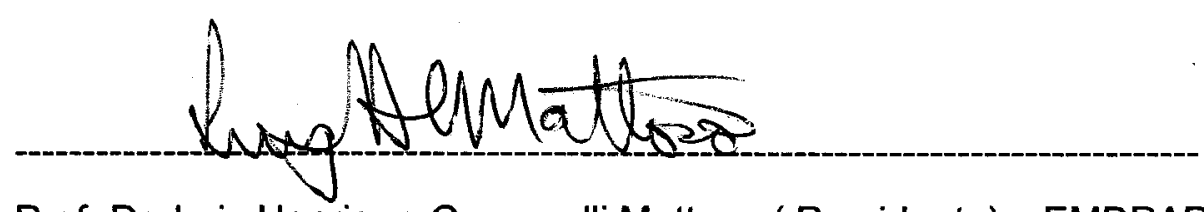

Prof. Dr. Luiz Henrique Capparelli Mattoso (Presidente) - EMBRAPA

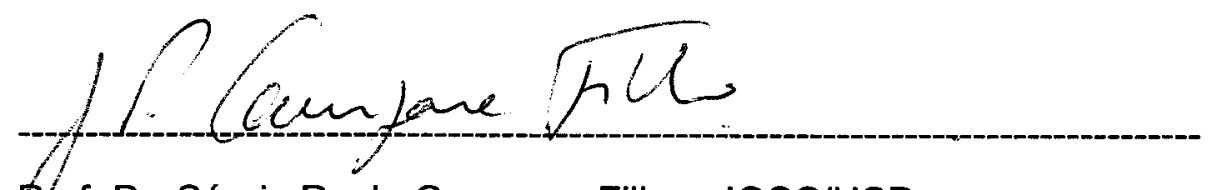

Prof. Dr. Sérgio Paulo Campana Filho - IQSC/USP

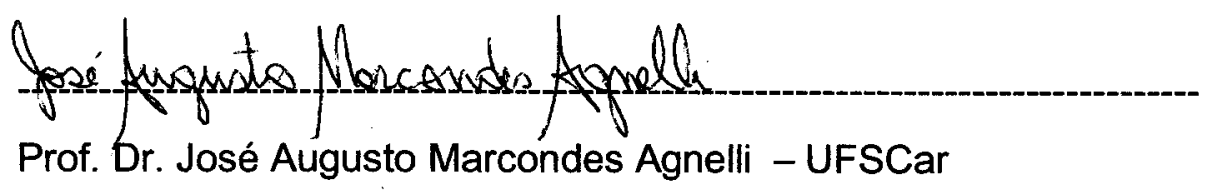


Dedico este trabalho...

À DEUS pelo dom da vida.

“Aprendi a adaptar-me às necessidades; sei viver na abundância, e sei também como haver-me na penúria. Tudo posso naquele que me fortalece. Eis um verdadeiro soldado da milícia celeste, e não pó, como somos nós. Mas, recorda-te Senhor, que somos pó e com o pó fizeste o homem. Lembra-te que esse homem estava perdido e foi reencontrado. Nem o Apóstolo - também ele era pó - encontrou força em si mesmo, ele que, por tua inspiração, disse aquilo que tanto me agrada: Tudo posso naquele que me fortalece."

Santo Agostinho

Aos meus pais José Adilson e Antonia e ao meu irmão Júnior, pelo amor, oportunidade e sacrificios, sem os quais não teria chegado até aqui. Obrigada por tudo. 
- Ao Dr. Luiz Henrique Capparelli Mattoso pela orientação e principalmente pelo apoio, amizade e confiança, depositados em mim, sem os quais esse trabalho não teria sido realizado.

- Ao Dr. Aldo E. Job pesquisador da FAPESP/UNESP - Presidente Prudente pela paciência, treinamento e uso dos equipamentos de análise térmica.

- Ao Dr. Paulo de Souza Gonçalves da Embrapa/IAC pela atenção e ajuda.

- Ao Rogério Moreno e a Maria Alice Martins pelo apoio, ajuda e discussões fundamentais para a realização deste trabalho.

- À Cristina Picci, da Embrapa Pecuária Sudeste, pela atenção e obtenção das análises do teor de nitrogênio.

- Ao funcionário Renê de Oste, da Embrapa Instrumentação Agropecuária, pela ajuda no trabalho de coleta do látex $e$, pela ajuda nos diversos problemas surgidos durante o trabalho.

- À Ana Maria Felicori pela confecção dos relatórios de aplicação dos recursos de reserva técnica.

- Ao Éliton Medeiros pela ajuda durante os ensaios de tração e discussões.

- Ao Fábio C. Ferreira pela ajuda nas análises térmicas.

- À Elisângela pela ajuda nas análises de DSC.

- À Embrapa Instrumentação Agropecuária, funcionários e amigos, pela convivência e pelo apoio concedido.

- À todos que direta ou indiretamente contribuíram para a realização deste trabalho.

- À FAPESP pelo apoio financeiro. 


\section{ÍNDICE}

Lista de Figuras

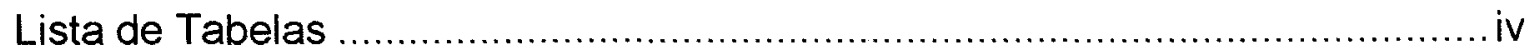

Lista de Abreviaturas e Siglas .......................................................

Lista de Símbolos .............................................................................. vi

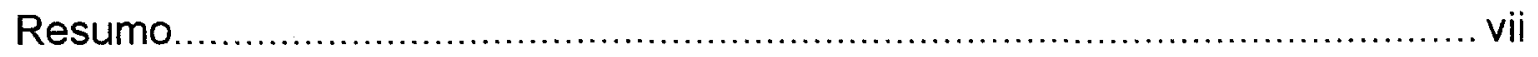

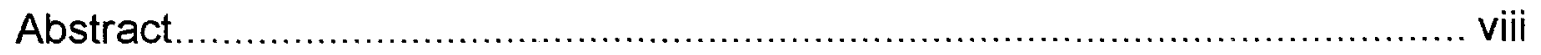

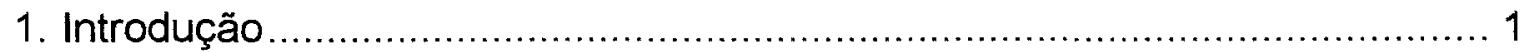

2. Fundamentação Teórica e Revisão da Literatura .................................... 3

2.1. Aspectos Gerais...................................................................... 3

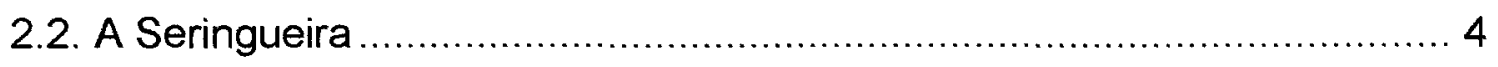

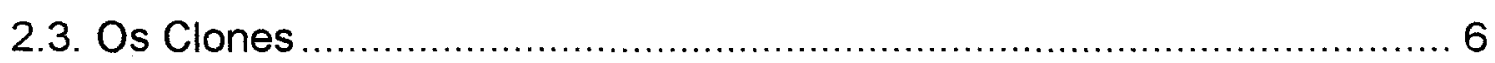

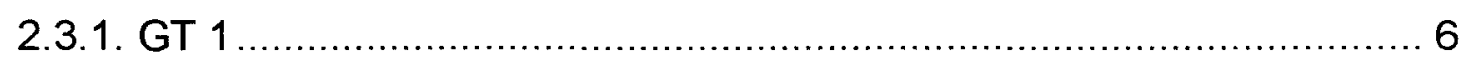

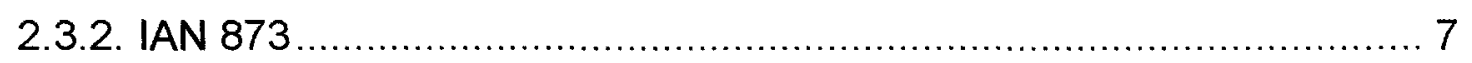

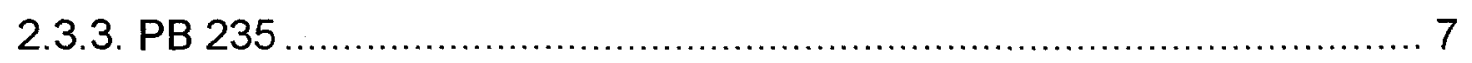

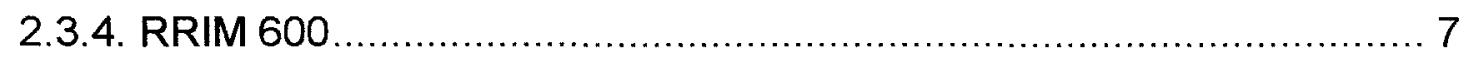

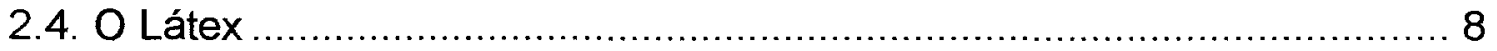

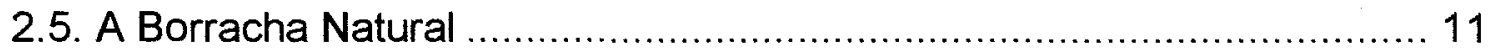

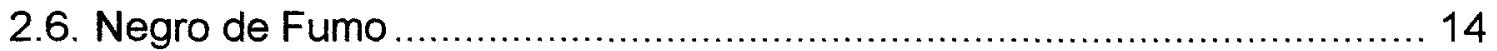

2.7. Vulcanização e Formulação......................................................... 15

2.8. Propriedades da Borracha Natural............................................ 21

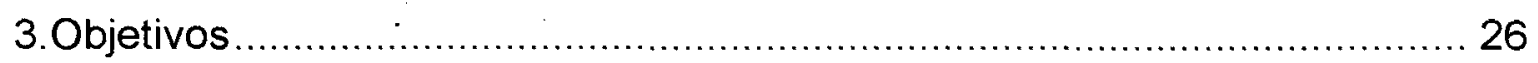

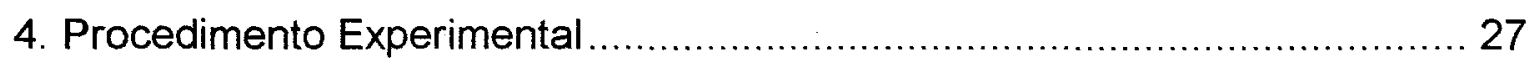

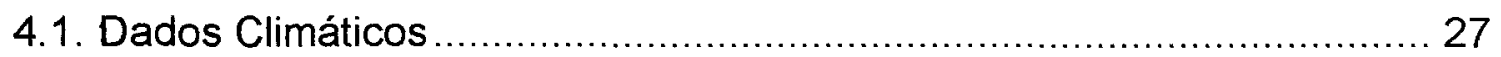

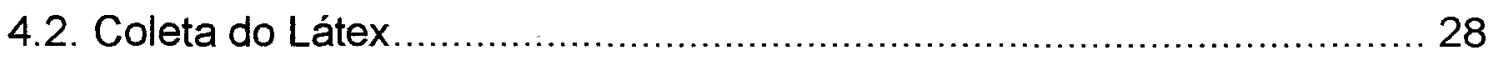

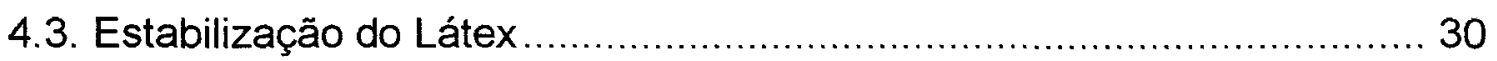

4.4. Coagulação do Látex ........................................................... 30

4.5. Análises de Rotina no Látex ...................................................... 31

4.5.1. Determinação do teor de cinzas ............................................. 31

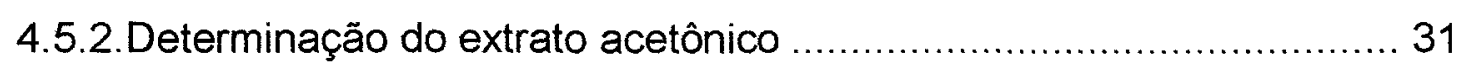


4.5.3. Determinação do teor de nitrogênio .................................... 32

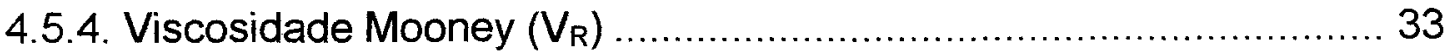

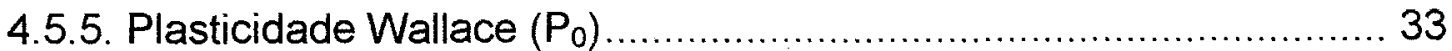

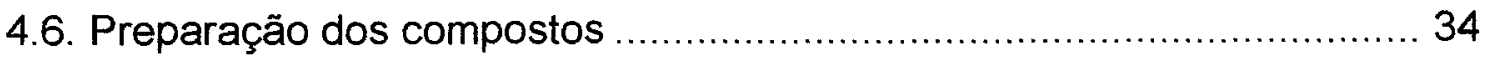

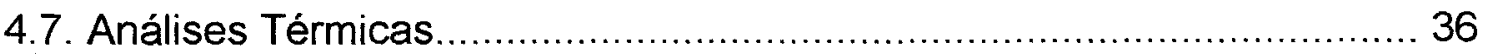

4.7.1. Análise Térmica-Dinâmico-Mecânica (DMTA) ........................... 36

4.7.2. Calorimetria Diferencial de Varredura (DSC) .................................. 36

4.7.3. Análise Termo-Gravimétrica (TGA) ...................................... 37

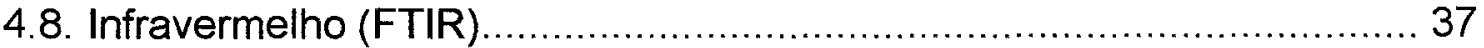

4.9. Microscopia Eletrônica de Varredura (MEV) ................................ 37

4.10. Ensaios de Tração ............................................................ 38

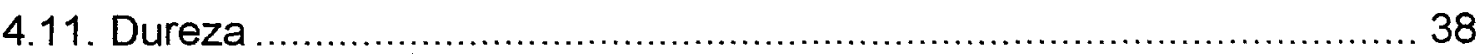

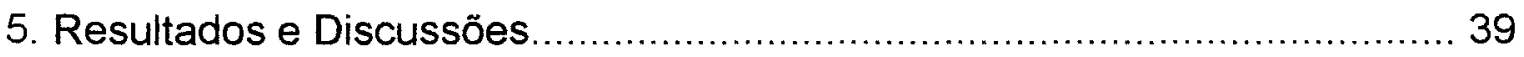

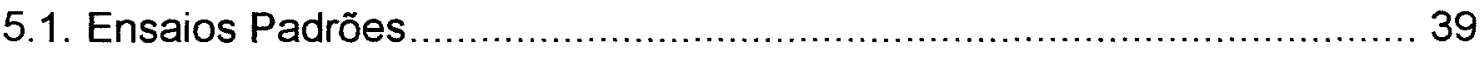

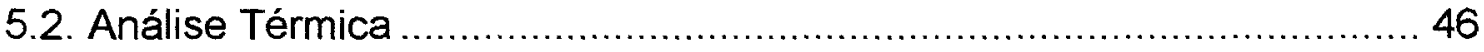

5.2.1. Análise térmica-dinâmico-Mecânica (DMTA) ............................. 49

5.2.2. Calorimetria Diferencial de Varredura (DSC) ............................ 56

5.2.3. Análise Termogravimétrica (TGA) ...................................... 59

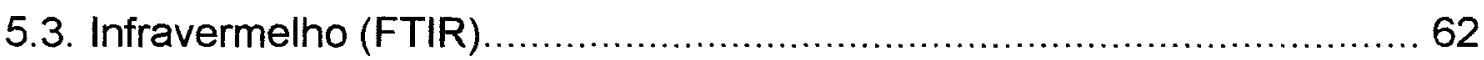

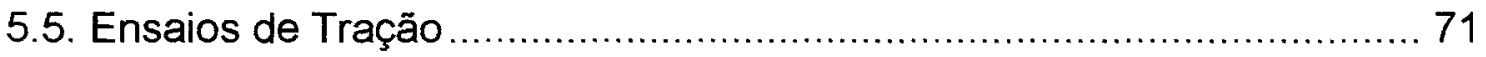

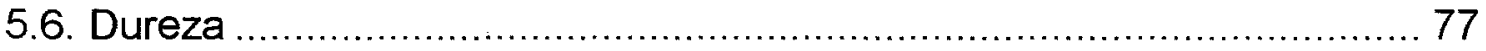

5.7. Discussão final dos resultados ................................................. 78

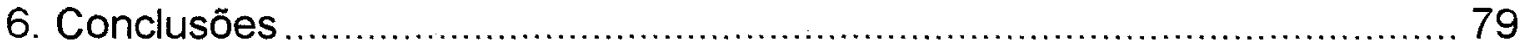

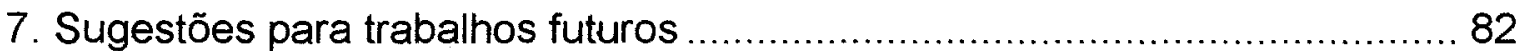

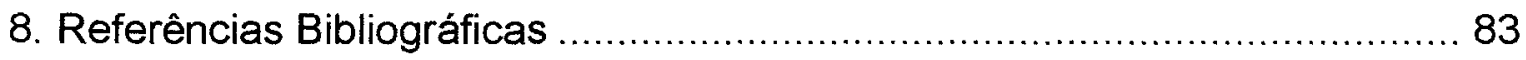

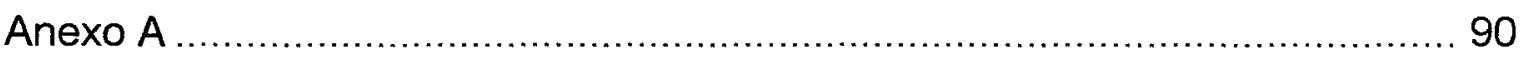


Figura 01. Esquema do caule da seringueira (Hevea brasiliensis). 10

Figura 02. Estrutura química das unidades cis-1,4 e trans-1,4, presentes na composição da borracha natural

Figura 03. Estrutura química da borracha natural poli(cis-1,4-isopreno). 12

Figura 04. Representação esquemática do processo de vulcanização da borracha. 16

Figura 05. Modelo da formação de ligações cruzadas das cadeias do cis-1,4poliisopreno, pelos átomos de enxofre. 17

Figura 06. Foto ilustrativa da coleta do látex...... .28

Figura 07. Exp. de avaliação de clones em grande escala de Votuporanga.....29 Figura 08. Curvas do fator amortecimento $(\tan \delta$ ) versus temperatura para as amostras de borracha natural crua. 49

Figura 09. Curvas do fator amortecimento $(\tan \delta$ ) versus temperatura dos compostos: blenda, borracha comercial, GT 1, IAN 873, PB 235 e RRIM 600 com tempo de vulcanização de 5 minutos. 50

Figura 10. Curvas do fator amortecimento $(\tan \delta$ ) versus temperatura da borracha comercial comparando-se os tempos de vulcanização $(5,7$ e 9 minutos) com a borracha crua. 52

Figura 11. Curvas do módulo de armazenamento ( $\left.E^{\prime}\right)$ versus temperatura para as amostras de borracha natural crua.

Figura 12. Curvas do módulo de armazenamento ( $\left.E^{\prime}\right)$ versus temperatura dos compostos: blenda, borracha comercial, GT 1, IAN 873, PB 235 e RRIM 600 com tempo de vulcanização de 5 minutos. 55

Figura 13. Curvas do módulo de armazenamento ( $\left.E^{\prime}\right)$ versus temperatura do clone PB 235 comparando os tempos de vulcanização 55

Figura 14. Curvas de DSC para as amostras de borracha natural crua.. .56

Figura 15. Curvas de DSC dos compostos: blenda, borracha comercial, GT 1 , IAN 873, PB 235 e RRIM 600 com tempo de vulcanização de 5 minutos 57 
Figura 16. Curva de DSC do clone IAN 873 , com tempo de vulcanização de 5 minutos com a primeira derivada - processo para obter o valor da $\mathrm{Tg}$. .58

Figura 17. Curvas de DSC da borracha comercial comparando-se os tempos de vulcanização 59

Figura 18. Curva de TGA das amostras de borracha natural crua. 60

Figura 19. Curvas de TGA dos compostos: blenda, borracha comercial, GT 1 , IAN 873, PB 235 e RRIM 600 com tempo de vulcanização de 5 minutos. 60

Figura 20. Curva de TGA dos compostos com tempo de vulcanização de 5 minutos, para uma melhor visualização da perda de massa. 61

Figura 21. Curvas de DSC do clone PB 235 comparando os tempos de vulcanização (5, 7 e 9 minutos) e com a borracha natural crua. 62

Figura 22. Curvas de FT-IR separados por regiões de absorção dos compostos: blenda, borracha comercial, GT 1, IAN 873, PB 235 e RRIM 600 com tempo de vulcanização de 5 minutos.

Figura 23. Curvas de FT-IR separados por regiōes de absorção do clone RRIM 600 comparando os tempos de vulcanização (5, 7 e 9 minutos). .66

Figura 24. Fotografia obtida por MEV da seção fraturada em nitrogênio líquido da blenda, com vulcanização de 5 minutos. Ampliação de 5000x 67

Figura 25. Fotografia obtida por MEV da seção fraturada em nitrogênio líquido do clone GT 1, com vulcanização de 5 minutos. Ampliação de 5000x. 68 Figura 26. Fotografia obtida por MEV da seção fraturada em nitrogênio líquido do clone GT 1, com vulcanização de 7 minutos. Ampliação de 5000x. .68 Figura 27. Fotografia obtida por MEV da seção fraturada em nitrogênio líquido do clone GT 1, com vulcanização de 9 minutos. Ampliação de 5000x. 69 Figura 28. Fotografia obtida por MEV da seção fraturada em nitrogênio líquido. A - blenda ( 7 minutos) e B - Comercial (9 minutos). Ampliação de 5000x ......70 Figura 29. Fotografia obtida por MEV da seção fraturada em nitrogênio líquido. C - GT 1 (5 minutos) e B - IAN 873 (9 minutos). Ampliação de 5000x. 70

Figura 30. Fotografia obtida por MEV da seção fraturada em nitrogênio líquido. E - PB 235 (7 minutos) e F - RRIM 600 (9 minutos). Ampliação de 5000x....71 
Figura 31. Gráfico tensão versus deformação para os compostos de borracha natural vulcanizados a 5 minutos. .72

Figura 32. Gráfico tensão versus deformação para os compostos de borracha natural vulcanizados a 7 minutos. .72

Figura 33. Gráfico tensão versus deformação para os compostos de borracha natural vulcanizados a 9 minutos .73

Figura 34. Gráfico tensão versus deformação para os compostos do RRIM 600 para os tempos vulcanização de 5, 7 e 9 minutos. .76

Figura 35. Produção dos clones da região de Votuporanga. .78 
Tabela 01. Composição dos compostos de borracha natural. 35

Tabela 02. Valores médios obtidos para o teor de cinzas das amostras de borracha natural. 39

Tabela 03. Valores médios obtidos para o extrato acetônico das amostras de borracha natural. 40

Tabela 04. Valores médios obtidos para o teor nitrogênio das amostras de borracha natural.

Tabela 05. Valores médios obtidos para a viscosidade Mooney das amostras de borracha natural.

Tabela 06. Valores médios de plasticidade e PRI das amostras de borracha natural.

Tabela 07. Valores da Tg para as amostras de borracha natural crua, através das técnicas de DSC e DMTA.

Tabela 8. Valores da $\mathrm{Tg}$ para as amostras de borracha natural vulcanizadas com diferentes tempos de vulcanização, através das técnicas de DSC e DMTA. 48

Tabela 09. Principais bandas encontradas na literatura para o cis-poliisopreno e suas atribuições.

Tabela 10. Valores de tensão, deformação e módulo para as amostras de borracha natural com tempo de vulcanização de 5 minutos. .73

Tabela 11. Valores de tensão, deformação e módulo para as amostras de borracha natural com tempo de vulcanização de 7 minutos.

Tabela 12. Valores de tensão, deformação e módulo para as amostras de borracha natural com tempo de vulcanização de 9 minutos. 74

Tabela 13. Média e desvio padrão da dureza Shore A para os compostos de borracha natural 
RRIM 600 - Clone Rubber Research Institute of Malasia 600

GT 1 - Clone Gondang Tapen 1

IAN 873 - Clone Instituto Agronômico do Norte 873

PB 235 - Clone Prang Besar 235

IAC - Instituto Agronômico de Campinas

DSC - calorimetria diferencial de varredura

TGA - análise termogravimétrica

DMTA - análise térmica dinâmico-mecânica

MEV - microscopia eletrônica de varredura

PRI - índice de retenção de plasticidade

$\mathbf{V}_{\mathbf{R}}$ - viscosidade Mooney

$\mathbf{P}_{\mathbf{0}}$ - plasticidade Wallace

Tg - temperatura de transição vítrea

phr - per hundred of rubber

MBTS - 2,2-dissulfeto benzotiazil

TMTD - tetrametiltiuram dissulfeto

GEB 1 - borracha de coagulados diversos, Granulado-Escuro-Brasileiro

C.V. - coeficiente de variação 


\section{LISTA DE SímBOLOS}

- Média

s - Desvio Padrão

$\sigma$ - Tensão de Ruptura

$\varepsilon$ - Deformação

E - Módulo de Young 
Este trabalho teve por objetivo estudar o desempenho mecânico e térmico de compostos de borracha natural de diferentes tipos de clones (GT 1, IAN 873, PB 235 e RRIM 600). A qualidade do látex de borracha natural dos diferentes clones de seringueiras (Hevea brasiliensis) recomendados para 0 Estado de São Paulo, foram avaliadas por ensaios padrões (plasticidade Wallace, PRI, viscosidade Mooney, \% de cinzas, extrato acetônico e \% de nitrogênio). Estas borrachas foram formuladas em cilindro e vulcanizadas com tempos de 5, 7 e 9 minutos. A avaliação do desempenho mecânico e térmico dos diferentes compostos de borracha natural foram realizados por Calorimetria Diferencial de Varredura (DSC), Análise Termogravimétrica (TGA), propriedades mecânicas de tração e dureza, caracterização por Análise Térmica-Dinâmico-Mecânica (DMTA), Microscopia Eletrônica de Varredura (MEV) e Espectroscopia no Infravermelho com Transformada de Fourier (FTIR). O desempenho mecânico e térmico foram comparados e correlacionados com as características da borracha crua. Os valores obtidos para temperatura de transição vitrea $(\mathrm{Tg})$, foram inferiores a $-56^{\circ} \mathrm{C}$ para as borrachas vulcanizadas e de $-62^{\circ} \mathrm{C}$ para as borrachas cruas, a blenda crua apresentou um menor valor ($92,5^{\circ} \mathrm{C}$ ), devido a uma maior mastigação para a homogeneização da amostra, não apresentando grandes variações em relação ao tempo de vulcanização e ao tipo de clone. Os ensaios de tração mostraram que um dos clones mais produtivos (RRIM 600) obteve o melhor desempenho mecânico. As borrachas formuladas, obtiveram no ensaio de dureza valores próximos de 60 Shore $A$, não variando em relação ao tempo de vulcanização e ao tipo de clone. Todas as amostras estudadas ficaram dentro dos padrões de qualidade exigidos. De acordo com os resultados obtidos neste trabalho e com a literatura, todos os clones estudados, incluindo os mais produtivos (PB 235 e RRIM 600) podem ser utilizados nas indústrias de artefatos de borracha separadamente ou na forma de blenda. 
The objetive of this work was to study the mechanical and thermal performance of natural rubber composites of different types of clones (GT 1, IAN 873 , PB 235 and RRIM 600). The latex quality of different natural rubber clones (Hevea brasiliensis) recommended for plantation in the State of São Paulo were evaluated by standards methods (Wallace plasticity, PRI, Mooney viscosity, content percentage, acetonic extract and nitrogen content percentage). These rubbers were formulated and prepared in a mill and vulcanized at different times $(5,7$ and $9 \mathrm{~min}$.). The evaluation of the mechanical and thermal performance of different natural rubber composites was carried out by differential scanning calorimetry (DSC), thermogravimetry (TGA), mechanical properties (tensile and hardness tests), dynamic mechanic thermal analysis (DMTA), scanning electron microcospy (SEM) and Fourrier thansform infrared spectroscopy (FTIR). The mechanical and thermal performance were compared and correlated with the characteristics of the raw rubber. The values obtained for glass transistion temperature $(\mathrm{Tg})$ were found to be bellow $-56^{\circ} \mathrm{C}$ for vulcanized rubbers and of$62^{\circ} \mathrm{C}$ for raw rubbers, without having great variations in relation to the vulcanization time and type of clone. The tensile tests showed that the best performance was obtained for the most productive clone (RRIM 600). Hardness test values obtained were close to 60 , without varying in relation to the vulcanization time and the type of clone. All the samples studied were in agreement with standard specifications required for application in the rubber industry. According to these results and related literature, all clones including the most productive ones (PB 235 and RRIM 600) can be used in the rubber industry in blended or unblended forms. 


\section{INTRODUÇÃO}

Atualmente, a produção de borracha natural no país é responsável por apenas $1 \%$ da produção mundial, insuficiente para o consumo interno, forçando a importação de cerca de $60 \%$ da borracha consumida no país. Outro aspecto relevante é que a qualidade e produtividade da borracha natural brasileira estão, em geral, abaixo dos niveis da importada. Verifica-se a carência de projetos voltados para avaliar as propriedades da borracha natural, visando a melhoria da qualidade do produto ${ }^{(1,2)}$

O Brasil possui em relação aos demais países produtores, áreas incomparavelmente mais aptas ao plantio de seringueira. O déficit na produção significa, no mínimo, descaso para um produto estratégico de alto valor econômico-social. O Estado de São Paulo possui 14 milhões de hectares aptos à heveicultura e desse total só cerca de 44,6 mil hectares estavam ocupados com seringueiras em $1997^{(1)}$

O aumento da produtividade pode levar o Brasil à auto-suficiência na produção de borracha, mas dependerá do aprimoramento de tecnologias para auxiliar os produtores e os beneficiadores. Uma das mais notáveis contribuições da Secretaria de Agricultura e Abastecimento do Estado de São Paulo foi a introdução do clone RRIM 600 em 1952 pelo Instituto Agronômico de Campinas (IAC) e sua posterior expansão na década de 60 pelos órgãos competentes da época da referida Secretaria. Estima-se que hoje mais de 8000 dos 50 mil hectares da área total de seringueira do Estado esteja plantada com o clone 
RRIM 600, cuja prática continuada poderá se aproximar a uma situação de plantio monoclonal, o que poderá levar à conseqüências desastrosas como epidemias de pragas e doenças comuns em monocultivos em conseqüência da presença de pouca variabilidade genética nos seringais ${ }^{(2)}$. Embora ainda estejamos longe de vivenciar tal situação, com isso há a necessidade de estudos das propriedades dos novos clones.

O IAC desenvolve projetos no Estado de São Paulo para o melhoramento genético de novos clones de seringueira pelos caracteres: produção de borracha seca, vigor expresso pela circunferência do caule, espessura de casca e antracnose do painel; tipo e freqüência de sangria. No entanto, existe ainda uma grande demanda para a avaliação do desempenho (qualidade e uniformidade) dos produtos extraídos destes vegetais no Brasil, tanto antes da formulação de compostos de borracha natural como após o seu processamento final na forma de um produto. Neste contexto este trabalho é uma colaboração entre IAC e Embrapa que tem como objetivo desenvolver, caracterizar e comparar as propriedades dos compostos de borracha natural de diferentes clones e correlacionar as propriedades da borracha natural antes e após a sua formulação. As propriedades térmicas e mecânicas destes compostos foram analisadas por calorimetria diferencial de varredura (DSC), análise termogravimétrica (TGA), propriedades de tração, dureza, caracterização por análise térmica-dinâmico-mecânica (DMTA), sendo também investigado por microscopia eletrônica de varredura (MEV) e espectroscopia na região do infravermelho. 


\section{FUNDAMENTAC̄̃̃ TEÓRICA E REVISÃO DA LITERATURA}

\subsection{AsPECTOS GERAIS}

Os padrões de qualidade para a classificação técnica da borracha são definidos em função de certos parâmetros considerados relevantes. Entre os diferentes esquemas propostos e utilizados ocorrem algumas nuances diferenciais, embora, em essência, todos se identificam. No esquema Standard Malaysian Rubber ${ }^{(4)}$, o tipo destinado para usos gerais (SMR-General Purpose) é qualificado em função dos seguintes parâmetros: \% de sujidade, \% de cinzas, $\%$ de nitrogênio, \% de voláteis, indice de retenção de plasticidade (PRI), Viscosidade Mooney $\left(V_{R}\right)$ e características de vulcanização.

O teor de cinzas $^{(5)}$ reduz a borracha a somente os componentes inorgânicos não decompostos à temperatura de aproximadamente $570^{\circ} \mathrm{C}$, enquanto todas as substâncias de natureza orgânica são destruídas nessa temperatura. $\mathrm{O}$ excesso de cinzas, além de poder reduzir as propriedades dinâmicas do vulcanizado, tem grande possibilidade de provocar efeito depressivo nas propriedades de envelhecimento.

A porcentagem de extrato acetônico ${ }^{(5)}$ é representado pela fração nãoborracha solúvel em acetona, tendo como principais componentes os ácidos graxos, ésteres de esteróis, em adição a um número de outras substâncias de menor importância, sendo que os altos valores de extrato acetônico influenciam negativamente nas características físicas do produto acabado. 
O conteúdo de nitrogênio ${ }^{(5)}$ combinado, na borracha, é um fator muito importante. Ele expressa o excesso ou a deficiência de substâncias nitrogenadas que influenciam, depois que a borracha é processada e vulcanizada, as propriedades de resistência do produto obtido.

A plasticidade, ou viscosidade da borracha ${ }^{(5)}$ se reveste de real importância, já que a mesma só poderá ser devidamente processada quando forem incorporados os diversos ingredientes para vulcanizar e promover os diferentes efeitos desejados e esperados no artigo a ser fabricado. Desde logo, admite-se que as borrachas excessivamente duras, com elevados valores de plasticidade na escala Mooney ou Wallace, nem sempre são as preferidas, já que elas consomem excesso de mão-de-obra, tempo e energia por ocasião do processamento.

\subsection{A SERINGUEIRA}

A seringueira Hevea brasiliensis é a maior fonte de borracha natural, matéria-prima utilizada nas indústrias de transportes e produtos bélicos, indústrias de artefatos leves (luvas cirúrgicas, preservativos, chupetas, solados, etc.). Cerca de 50 mil artigos existentes são feitos de borracha, e cerca de 600 Kg são necessários em um aeroplano e 68 toneladas em um navio de guerra ${ }^{(5)}$.

A Hevea brasiliensis é uma árvore, de crescimento rápido, apresentando grande capacidade de reciclagem de carbono, transformando-o em látex, madeira, etc., contribuindo assim para a redução de problemas ambientais. São 
replantadas depois de $25-35$ anos, devido a queda da produção a um nível economicamente inviável ${ }^{(1,6)}$.

Após a sua implantação, o seringal constitui um sistema estável, apresentando características de floresta tropical, podendo ser sangrado a partir do sexto ou sétimo ano e alcançando o máximo de produção do quarto ano após a primeira sangria em diante. É uma cultura nobre, conservando o solo, melhorando o meio ambiente, gerando empregos e riquezas, permanecendo viva e produtiva por longo tempo, além de viabilizar mais uma cultura alternativa e permitir a atualização de áreas degradadas ou imprestáveis para o cultivo de culturas anuais $^{(1,7)}$.

A produtividade da seringueira e a qualidade do látex dependem da capacidade de regeneração do látex pela árvore entre duas extrações consecutivas (sangrias) e da duração do fluxo do látex durante a sangria. $\mathrm{O}$ fluxo depende de vários parâmetros, como a pressão turgor existente no interior dos vasos laticíferos responsáveis pela expulsão do látex no momento da sangria, processos de transferência de água dos tecidos do floema para os tecidos laticíferos e processos envolvidos na coagulação do látex responsáveis pelo processo que interrompe o fluxo.

A regeneração do látex é controlada por fatores como: suprimento de sacarose nos laticíferos, quantidade de energia (ATP) bioquímica necessária nos processos de regeneração in situ, e processos envolvidos em reações antioxidantes responsáveis por proteger as células de espécies como oxigênio ativo $\left(\mathrm{O}_{2}, \mathrm{H}_{2} \mathrm{O}_{2}, \mathrm{OH}^{-}\right)$, subprodutos de reações que ocorrem nos laticíferos. Outros 
fatores determinantes são a freqüência de sangria e o uso de estimulantes ${ }^{(8-10)}$. A utilização de estimulantes e a baixa freqüência de sangrias podem trazer benefícios econômicos, devido à redução nos custos de mão-de-obra (responsável por $70 \%$ dos custos de produção) e à maior produtividade. No entanto, estas características dependem do tipo de clone e da região.

\subsection{OS CLONES}

Um clone é formado por um grupo de plantas obtidas através da propagação vegetativa de uma planta matriz. Todas as árvores de um clone possuem a mesma constituição genética, responsável por sua uniformidade ${ }^{(11)}$.

Em geral os clones recebem o nome da instituição de origem, sob forma de sigla, seguido após um espaço, de um número de série designado pelo melhorista responsável ${ }^{(12)}$. Os clones estudados neste trabalho foram:

- RRIM 600 - Rubber Research Institute of Malasia 600

- GT 1 - Gondang Tapen 1

- IAN 873 - Instituto Agronômico do Norte 873

- PB 235 - Prang Besar 235

\subsubsection{GT 1}

O clone primário desenvolvido no seringal Gondang Tapen, em Java, Indonésia, foi denominado GT 1. É um clone muito homogêneo e considerado de excelente produção. Demonstra uma tendência de aumentar a produção de látex com o passar do tempo. O látex é branco e não amarelado como acontece 
em outros casos, adequado para todos os processos de produtos. Por ser precoce e pela sua rusticidade e qualidades agronômicas, deve ser recomendado para pequenos heveicultores do Planalto Paulista ${ }^{(11)}$.

\subsubsection{IAN 873}

Este clone foi desenvolvido pelo antigo Instituto Agronômico do Norte e é um clone secundário cujos parentais são os clones primários PB 86 e FB 1717. A alta produção a partir do terceiro ano é seu ponto de destaque. O clone exibe tendência de produção crescente. Via de regra, a produção inicial é média, porém as produções subseqüentes são altas. Quando plantados em regiões com déficit hídrico demonstrou considerável sensibilidade, com queda de produção de 20 a $30 \%$ em um veranico de quarenta dias ${ }^{(11)}$.

\subsubsection{PB 235}

Clone secundário resultante do cruzamento dos clones PB 5/51xPBS $/ 72$ em Prang Besar, originário da Malásia. No município de Tabapuã - SP, a sangria teve início aos cinco anos e meio e comercialmente, aos seis anos. Caracteriza-se principalmente por entrar em regime de produção muito rapidamente, que é favorecido por sua grande homogeneidade ${ }^{(11)}$.

\subsubsection{RRIM 600}

Clone secundário desenvolvido pelo Rubber Research Institute of Malaysia - RRIM, cujos parentais são os clones primários Tjir 1 e PB 86. No 
Estado de São Paulo esse clone é considerado suscetível ao vento. A alta produção é seu ponto de destaque. Em geral, a produção inicial é média, as subseqüentes são muito altas. O látex é branco e impróprio para concentração, devido à baixa estabilidade. É o clone mais plantado na região do Planalto Paulista por apresentar bom desempenho no que tange a produção e o vigor ${ }^{(11)}$.

\subsection{O LÁTEX}

O látex é convenientemente definido como uma dispersão coloidal de uma substância polimérica em um meio aquoso. É um complexo sistema citoplasmático, de partículas coloidais polidispersas suspensas em um soro. Dois tipos de partículas predominam: as de borracha e a de lutóides (não borracha). O látex é constituído aproximadamente de $30-45 \%$ de massa de hidrocarbonetos e os constituintes não borracha somam-se 3-5\% dependendo de alguns fatores, tais como o tempo, clone, freqüência de sangria, solo, estação do ano, etc. Destacam-se ainda os complexos de Frey-Wyssling (estas partículas são constituídas de carotenóides e lipídios conferindo a borracha uma coloração levemente amarelada) e o soro $\mathrm{C}$, que contém proteínas aniônicas e sais minerais que conferem estabilidade coloidal ao sistema. Os constituintes não borracha compreendem: proteínas, aminoácidos, carboidratos, lipídios, aminas, ácidos nucleícos e nucleotídeos e outros constituintes inorgânicos. Alguns desses compostos não-borracha estão dissolvidos ou suspensos no meio aquoso do látex, enquanto os outros estão adsorvidos na superfície das partículas de borracha ${ }^{(13-15)}$. 
As partículas de borracha possuem forma esférica e são constituídas de poli(cis-1,4-isopreno), e envolvidas por uma membrana protéica fosfolipídica, que confere carga negativa à partícula, contribuindo para a estabilidade coloidal. O diâmetro destas partículas varia de 5,0 a $3.000 \mathrm{~nm}$, sendo que a maioria delas está na faixa de $100 \mathrm{~nm}$. Os lutóides são estruturas constituídas de proteínas, fosfolipídios e sais minerais, de 200 a $500 \mathrm{~nm}$, negativamente carregadas. No interior dos lutóides encontra-se o soro B, com carga elétrica positiva, devido ao excesso de cátions como $\mathrm{Ca}^{2+}, \mathrm{Mg}^{2+}, \mathrm{K}^{+}$e $\mathrm{Na}^{+}$e proteínas catiônicas, sendo por isso um dos fatores responsáveis pela coagulação do látex. Outro fator de coagulação sugerido é atribuído à ação de enzimas e bactérias ${ }^{(15)}$.

O hidrocarboneto isoprênico, principal constituinte da borracha, é um produto de biossíntese de certas espécies, entre as quais a mais importante é a Hevea brasiliensis. Encontra-se nos vasos laticiferos distribuídos no floema, entre a casca e o câmbio, conforme pode ser observado na Figura 1. Quando, por ocasião da sangria, se pratica uma incisão no tronco da árvore, seccionando-se os vasos laticíferos, observa-se de pronto o escoamento de um líquido branco-leitoso, às vezes amarelado, que genericamente, chama-se látex. O escoamento do látex é determinado pela pressão de turgor da ordem de 10 a 12 atmosferas reinante no interior dos vasos ${ }^{(15)}$. O látex natural no primeiro instante que escoa da seringueira, é de reação levemente alcalina, mas por efeito de ações químicas, e sobretudo bioquímicas vai se acidificando rapidamente em contato com o ar. 
raios

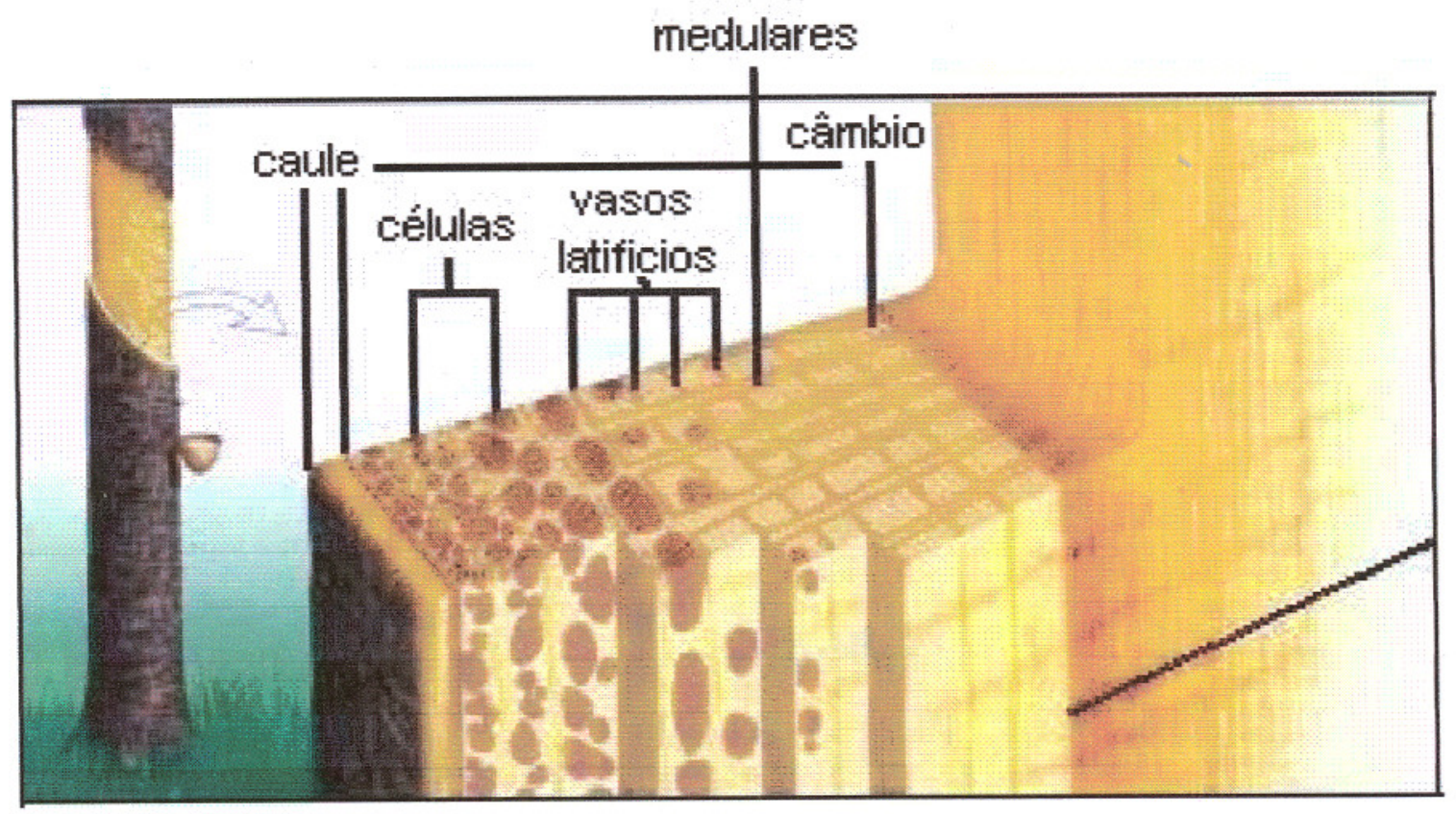

Figura 1. Esquema do caule da seringueira (Hevea brasiliensis). Fonte: La Recherche 276 Mai 1995, v. 26.

Pela composição do soro, que contém carboidratos, proteínas, sais minerais e microorganismos, pode-se prever que o látex é um produto perecível. De 8 a 10 horas após a colheita ele coagula espontaneamente, separando a borracha em forma de coágulo que com o correr do tempo, adquire cheiro putrefato ${ }^{(16)}$, isso devido, principalmente, à decomposição ou ao apodrecimento das proteínas.

Há muita especulação sobre a função do látex na planta. A sugestão que ele pode servir para transportar e estocar os nutrientes alimentares parece insustentável. Em primeiro lugar, os vasos laticíferos petiolares não podem transportar o fotossintetizado das folhas porque eles tornam-se bloqueados. Segundo, o látex pode ser dificilmente encarado como um estoque de reserva 
alimentar para ser utilizado em condições de "stress" da planta, desde que a borracha formada não é novamente metabolizada. Quando os coágulos estão expostos ao ar, o látex pode ter alguma ação protetora numa eventual injúria mecânica, mas não há evidência para isso, nem para a idéia de que ele detém 0 ataque de insetos ${ }^{(17)}$.

$\mathrm{O}$ ponto isoelétrico do látex de seringueira corresponde ao $\mathrm{pH} \mathrm{4,25} \mathrm{e} \mathrm{se}$ trata de um sistema fundamentalmente liófobo que adquire um notável grau de solvatação pelas substâncias de natureza protéica que são adsorvidas pelas partículas de borracha ${ }^{(17)}$.

\subsection{A BORRAcha NATURAL}

As borrachas naturais de uma maneira geral possuem unidades isoméricas do tipo isoprênica cis-1,4 e trans-1,4 (Figura 2). Contudo a literatura ${ }^{(18)}$ mostra que as borrachas de seringueira (Hevea brasiliensis) e do Guayule (Paternium argentatum) são poliisoprenos cis-1,4, contendo outras unidades isoméricas em baixa concentração. Por outro lado, existem outras espécies de borracha como é o caso da guta percha (Palaquium oblongfolium), que contêm apenas unidades trans-1,4.

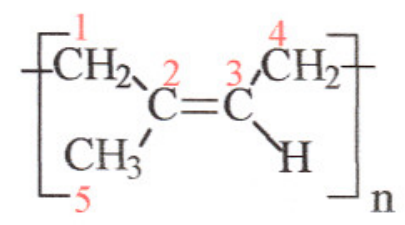

cis- 1,4<smiles>CCCCCC</smiles>

trans- 1,4

Figura 2. Estrutura química das unidades cis-1,4 e trans-1,4, presentes na composição da borracha natural. 
A borracha natural é essencialmente composta pelo poli(cis-1,4isopreno), na qual as unidades repetitivas da molécula são arranjadas na configuração cabeça-cauda ${ }^{(19)}$, como mostrado na Figura 3.

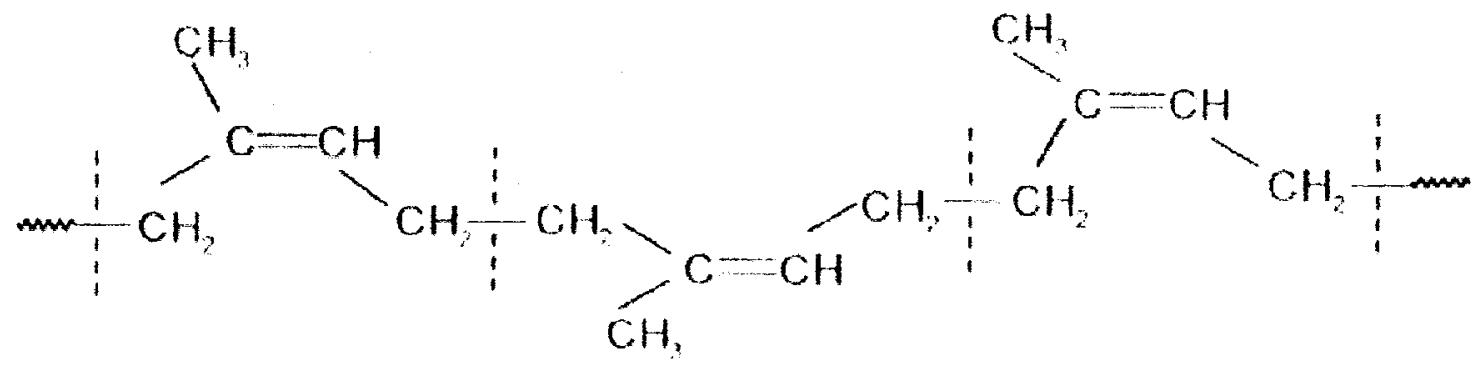

Figura 3. Estrutura química da borracha natural poli(cis-1,4-isopreno).

A borracha da Hevea brasiliensis é um polímero de alto massa molecular. A faixa de pesos moleculares dos clones, em geral, está entre $3 \times 10^{4}$ e $1 \times 10^{7}$, e o pico de maior massa molecular aparece em $1-2,5 \times 10^{6}$ e o de menor massa molecular a $1-2 \times 10^{5}$, havendo grandes variações no peso molecular médio entre borrachas de diferentes clones. Similarmente, a distribuição de peso molecular é também bem ampla, com a razão $M w / M n$ na faixa de 2,5 a $10^{(20)}$.

Subramaniam ${ }^{(21)}$ estudou a variação clonal do peso molecular e sua distribuição utilizando a técnica de cromatografia por permeação em gel (GPC). Embora a faixa de peso molecular seja praticamente a mesma para todos os clones estudados, os valores médios e os formatos das curvas de distribuição de massa molecular são diferentes. Enquanto os clones com borrachas com baixa e média massa molecular apresentam distribuição de massa molecular bimodal distinta, clones com borrachas de alta massa molecular usualmente 
apresentam uma distribuição unimodal. O peso molecular e sua distribuição variam de acordo com vários fatores, tais como: origem do clone, condições ambientais, métodos de isolação e tratamento das amostras antes das medidas.

As determinações da Viscosidade Mooney $\left(V_{R}\right)$ e da Plasticidade Wallace $\left(\mathrm{P}_{0}\right)$ dessas borrachas indicam correlações razoáveis com o peso molecular médio e a sua distribuição. As borrachas com altos pesos moleculares possuem altos $V_{R}$ e vice-versa. $O$ espalhamento dos pontos pode ser atribuído à larga distribuição de peso molecular, a influência dos constituintes não borracha e ao conteúdo de gel ${ }^{(22,23)}$.

Algumas propriedades da borracha mudam consideravelmente com a variação da temperatura. Quando a borracha é excessivamente resfriada para valores próximos da temperatura de transição vítrea $(\mathrm{Tg})$, torna-se quebradiça. No entanto, quando é resfriada, sem que mudanças irreversiveis ocorram, a borracha pode retornar ao seu estado original através do aquecimento e recuperar suas propriedades ${ }^{(24)}$.

Quando aquecidas as borrachas amolecem, tornando-se pegajosas e em temperaturas acima de $200{ }^{\circ} \mathrm{C}$ inicia-se a degradação. Alguns elastômeros quando aquecidos por um longo tempo (em temperaturas menores do que a temperatura de degradação) apresentam ligações cruzadas e tornam-se duras, como por exemplo, a borracha de butadieno-estireno ${ }^{(21)}$. 
Para que um polímero se comporte como borracha ele deve estar no estado amorfo, já que a cristalinidade restringe os movimentos moleculares necessários para a ocorrência da elasticidade.

Os tradicionais tipos de borracha do mercado internacional são as lâminas (folhas) e os crepes. Lâminas ou crepes procedem da coagulação ácida do látex convenientemente diluido. Há diferenças apreciáveis em relação aos sistemas de preparação e, conseqüentemente também em relação as características, propriedades e aplicações. As lâminas constituem o tipo de borracha de uso mais generalizado, enquanto que os crepes são de emprego mais restrito e mais especializado para certas linhas de aplicação ${ }^{(25)}$.

\subsection{NEGRO DE FUMO}

Negro de fumo é um termo genérico usado para identificar uma ampla variedade de materiais carbonáceos finamente divididos, produzidos através da decomposição térmica controlada de hidrocarbonetos aromáticos. A estrutura do negro de fumo difere quimica e fisicamente do grafite e do diamante. Estudos de microscopia eletrônica revelaram que as partículas consistem de planos de camadas de estrutura semelhante ao do grafite, porém menos perfeitas e concêntricas, sendo considerado como uma estrutura paracristalina (intermediário entre cristalino e amorfo). O teor de carbono pode variar de 83 a $93 \%{ }^{(19)}$. 


\subsection{VULCANIZAÇÃo E FORMULAÇÃO}

A borracha crua sem ser adicionada de outras substâncias, possui poucas aplicações, pois apresenta vários defeitos, como a baixa resistência à tração, são muito sensíveis às mudanças de temperatura, são atacadas com facilidade por alguns líquidos, entre outros.

Em 1839, Charles Goodyear descobriu a vulcanização da borracha, utilizando enxofre e carbonato de chumbo. Goodyear descobriu que, ao aquecer uma mistura de borracha natural, enxofre e carbonato de chumbo, a borracha passou de material termoplástico a elastomérico, e foi gradualmente introduzida em todos os campos da atividade humana, oferecendo novas possibilidades de aplicações ${ }^{(26)}$.

A vulcanização é um processo químico pelo qual as moléculas poliméricas se ligam umas as outras através da formação de ligações cruzadas com o enxofre (originando moléculas maiores), o que restringe o movimento molecular ${ }^{(25)}$, como se mostra na Figura 4. Hoje é sabido que a rede de ligações cruzadas formada pela vulcanização sem aceleradores ou em presença de aceleradores inorgânicos (em geral óxidos metálicos tais como de zinco, cálcio, magnésio ou chumbo) é muito complexa, mas a vulcanização com enxofre em ausência de aceleradores é um processo ineficaz ${ }^{(27)}$.

A palavra vulcanização foi inventada e sugerida a Hancok por William Brockedon, que derivou de Vulcano, o deus do fogo, significando assim que na vulcanização tanto o calor como o enxofre (que é de origem vulcânica) estão envolvidos na reação. Por outro lado, ao que tudo indica Goodyear utilizava-se 
mais da palavra cura para descrever o mesmo processo. De qualquer forma, vulcanização e cura são utilizados como sinônimos quando aplicados à borracha. ${ }^{(23)}$<smiles>CCC1=C(C)C(C)CC(C)C(C)C1(C)C</smiles>

(a)<smiles>CCC1SC(C)(C)C(C)(C(C)(C)C)SC1CC</smiles>

(b)

Figura 4. Representação esquemática do processo de vulcanização da borracha. (a) cadeia de cis-1,4-poliisopreno, antes da formação das ligações cruzadas com o enxofre. (b) a mesma cadeia depois da vulcanização (24).

A Figura 5 mostra esquematicamente como as ligações cruzadas com os átomos de enxofre conferem rigidez as moléculas de borracha, aumentando a resistência a tração da borracha natural ${ }^{(24)}$.

Basicamente, a vulcanização é a conversão da borracha através de um processo químico de ligações cruzadas ("crosslink"), levando-a de um estado essencialmente plástico para um estado essencialmente elástico ${ }^{(23)}$. 


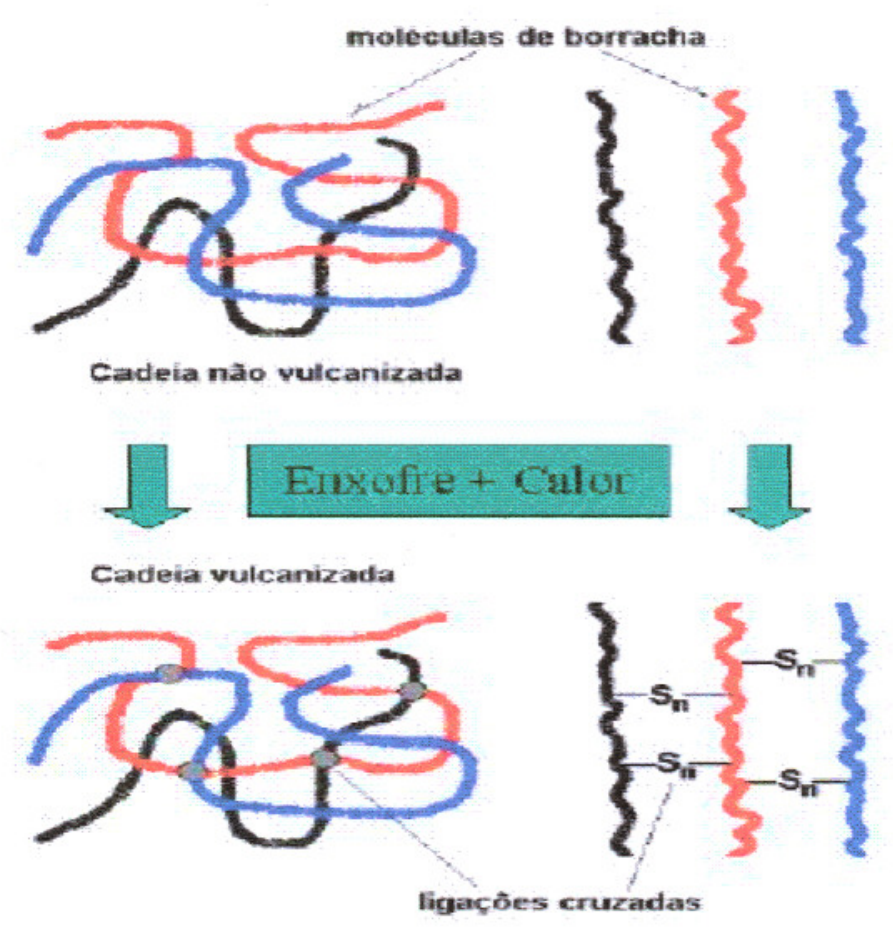

Figura 5. Modelo da formação de ligações cruzadas das cadeias do cis-1,4poliisopreno, pelos átomos de enxofre ${ }^{(23)}$.

Somente quando as ligações químicas são introduzidas entre moléculas vizinhas através da vulcanização, é que a borracha é convertida em material tecnicamente utilizável. As borrachas vulcanizadas ${ }^{(24)}$ devem conter uma rede de ligações cruzadas de baixa densidade para restringir os escoamentos relativos entre as cadeias poliméricas, já que estas poderiam deslizar uma sobre as outras ao ser aplicada uma tensão externa, e a recuperação seria incompleta. As ligações devem ser relativamente poucas, isto é, sem impedir a mobilidade dos segmentos de cadeia, e amplamente separadas de forma que 0 estiramento até grandes extensões possa ser possível sem a ruptura de ligações cruzadas. Esta habilidade de formar ligações cruzadas é tecnicamente a propriedade mais importante da borracha. O tipo, densidade e distribuição das 
ligações cruzadas são muito importantes na determinação das propriedades que $\circ$ composto de borracha irá assumir. Com o aumento das ligações cruzadas as forças de tensão alcançam um valor máximo e então diminuem, enquanto que a resiliência e a resistência a fluência continuam a aumentar com o aumento das ligações cruzadas. A formação das ligações cruzadas é um processo aleatório, com uma ligação sendo formada, em geral, a cada 100-200 unidades repetitivas, sendo que o principal agente de vulcanização é o enxofre ${ }^{(25)}$, por exemplo, um composto de borracha natural bem vulcanizada, no seu ótimo de cura, contém $5.10^{-5}$ moles de ligações cruzadas por grama de borracha. Para uma borracha com peso molecular de 250.000 unidades de massa atômica, isto significa aproximadamente 25 ligações cruzadas ao longo da cadeia de polímero, ou ainda uma média de 1 ligação para cada 150 unidades de isopreno ${ }^{(23)}$.

O passo mais importante com relação à química da vulcanização ocorreu com a descoberta dos aceleradores orgânicos, em 1900. Além de aumentarem a velocidade de vulcanização, esses aditivos trouxeram muitas vantagens. 0 uso de aceleradores permitiu o emprego de temperaturas mais baixas e tempos de vulcanização menores. Consequentemente, não houve mais a necessidade de submeter a borracha a condições drásticas e, deste modo, a possibilidade de degradação térmica e oxidativa foi minimizada ${ }^{(30)}$.

Através da vulcanização consegue-se transformar as propriedades plásticas da borracha, eliminar sua sensibilidade ao calor e obter um corpo elástico capaz de retomar suas dimensões primitivas depois de uma 
deformação, mesmo que em condições extremas de temperatura. Se esta característica não existisse, não poderia ter sido inventado o pneumático e sem este, provavelmente não haveria o automóvel nem o avião ${ }^{(27,30)}$.

A borracha no seu estado natural é de pouca aplicação, a mistura com outros ingredientes é que a torna útil para as aplicações mecânicas. Ao resultado desta mistura é dado o nome de composto de borracha.

Existe uma grande variedade de matérias-primas que podem ser utilizadas para modificar as propriedades químicas e físicas de um elastômero. Abaixo temos alguns motivos para a utilização desses ingredientes ${ }^{(23) \text {. }}$

- efetuar ligações cruzadas;

- incrementar as propriedades físicas da borracha;

- incrementar a processabilidade da borracha;

- controlar a taxa de vulcanização;

- prolongar a vida útil da borracha.

A incorporação das matérias-primas não pode ser feita sem submeter a borracha a um tratamento prévio. Nesse tratamento, que é o início do processo de fabricação de artefatos (processamento e prensagem), a borracha é trabalhada no misturador onde, pela operação de "mastigação" é "plasticizada" ou "plastificada", tornando-se mais mole e podendo então receber com facilidade outros materiais ${ }^{(27)}$, os quais os mais utilizados na indústria são:

- elastômero: polímero que à temperatura ambiente pode ser deformado repetidamente a pelo menos duas vezes o seu comprimento original. Retirado o esforço, deve voltar rapidamente ao tamanho original. 
- borracha: um elastômero natural ou sintético.

- plastificantes (óleos vegetais, ceras, RPA): facilitam a mistura, reduzem a dureza e o módulo.

- agentes vulcanizantes (enxofre, selênio, telúrio e alguns compostos orgânicos): produzem a vulcanização, reduzindo a plasticidade e aumentando a elasticidade.

- antioxidantes ( $\mathrm{N}-\mathrm{N}^{\prime}$-defenil-p-fenilenodiamina): melhoram 0 grau de resistência a degradação.

- aceleradores (thiurans): diminuem o tempo de vulcanização, melhorando as qualidades do vulcanizado.

- ativadores de aceleradores (óxido de zinco, ácido esteárico): intensificam a ação dos aceleradores.

- cargas de enchimento (caolim, carbonato de cálcio, talco): aumentam a dureza, reduzem a resistência à tração, reduzem o custo.

- cargas reforçadoras (negro de fumo, óxido de zinco): aumentam a resistência ao desgaste, a resistência à tração e à dureza.

- regenerado e recuperado: reduzem o custo, modificam os característicos do vulcanizado.

- pigmentos e corantes (óxido de titânio, óxido de ferro, azul da Prússia, anilinas): colorem as composições.

- retardadores de aceleradores (ácido salicílico): retardam a ação dos aceleradores, evitando a vulcanização prematura.

- enrigecedores (benzidina): reduzem a plasticidade das composições cruas. 
- abrasivos (pó de vidro, pedra pomes): conferem o poder de abrasão.

- agentes de expansão (bicarbonato de sódio, bicarbonato de amônio): produzem porosidade (fabricação de esponjas).

- aromatizantes (rodo-baunilha): encobrem o cheiro desagradável de certas composições.

\subsection{PropriEdades dA BORRACHA NATURAL}

No trabalho realizado por GOBINA et al. ${ }^{(31)}$ foi verificado a variação das propriedades tecnológicas $\left(P_{0}, P R I\right.$ e $\left.V_{R}\right)$ da borracha natural ao longo de um ano. Os resultados obtidos mostram muitas variações dessas propriedades ao longo de um ano em duas províncias do Camarões, tal como o trabalho realizado pelo grupo da Embrapa em Votuporanga ${ }^{(32)}$, apesar das diferenças climáticas entre estas duas regiões.

WEJESEKARA et al ${ }^{(33)}$ estudaram o efeito das condições de secagem nas propriedades da borracha natural. De um modo geral, as borrachas secas ao sol e defumadas (2 dias ao sol +2 dias de defumação) mostraram propriedades físicas equivalentes quando comparadas com as somente defumadas. Os resultados indicaram que as borrachas secas ao sol tiveram o valor do PRI maior do que o mínimo recomendado ( $P R I \geq 60)$. Os valores de PRI das borrachas defumadas, e das secas ao sol e defumadas, foram maiores que os das secas apenas ao sol. Esse comportamento pode ser devido a decomposição de substâncias fenólicas, durante o processo de defumação, propiciando um efeito antioxidante na borracha. 
As substâncias não borracha presentes a um nivel de $5 \%$ devem exercer uma influência considerável no envelhecimento da borracha natural. 0 conteúdo de algumas substâncias, tais como tocoferóis, proteínas e aminoácidos, têm demonstrado ter uma relação positiva com a resistência da borracha contra a oxidação. Essas devem, então, agir como antioxidantes naturais para a borracha. Alguns constituintes inorgânicos como $\mathrm{Cu}, \mathrm{Mn}$ e $\mathrm{Fe}$, por outro lado, demonstram ser pró-oxidantes da borracha. A proporção desses dois grupos de compostos na borracha controlará, então, a suscetibilidade da borracha à degradação oxidativa ${ }^{(4)}$.

D'AUZAC et al ${ }^{(34)}$ observaram mudanças significativas nos parâmetros fisiológicos como: TSC, $\mathrm{pH}$, conteúdo de fósforo inorgânico, tióis e sacarose no látex estimulado com ETHREL (ácido 2-cloroetilfosfônico) em estudo realizado na Costa do Marfim. O tratamento com estimulante permite maior fluidez do látex e maior estabilidade dos lutóides, fatores estes responsáveis pelo prolongamento do fluxo e maior atividade metabólica. Não existe nenhum trabalho na literatura fazendo uma avaliação e monitoramento das propriedades da borracha natural de diferentes clones plantados em larga escala, realizado no pais.

De acordo com SOARES et al ${ }^{(35)}$, a combinação de dois aceleradores é empregada quando se deseja alcançar uma maior segurança de processamento. O sistema binário MBTS/TMTD apresenta maior resistência a pré-cura quando comparado ao sistema contendo apenas TMTD. 
SOMBATSOMPOP et al ${ }^{(36)}$, estudaram a variação da temperatura de transição vítrea $(\mathrm{Tg})$, variando-se a quantidade de negro de fumo presente na formulação através da análise térmica-dinâmico-mecânica (DMTA), os quais observaram que não houve mudança significativa no módulo de E' na região da $\mathrm{Tg}$, e aumento nos valores da $\mathrm{Tg}$ aumentando-se a concentração de negro de fumo até aproximadamente 40 phr. Após essa concentração, verificaram que há uma diminuição no valor da $\mathrm{Tg}$, indicando que, neste caso, a carga promove um afastamento entre as cadeias macromoleculares da borracha, o que acarreta sua maior flexibilidade.

THANMATHORN et al ${ }^{(37)}$ estudaram o uso da cinzas de cascas do arroz como carga de enchimento em borracha natural vulcanizada em comparação com outros enchimentos comerciais, como talco, argila de china, carbonato do cálcio, silício e o negro de fumo. Neste estudo observaram que o negro de fumo fornece um maior reforço, melhores propriedades mecânicas (força, tensão, módulo, dureza, resistência à abrasão, resistência ao rasgamento) do que os outros enchimentos, como neste caso a cinza da casca do arroz, principalmente por causa de sua área superficial mais elevada (tamanho de partícula pequena e atividade de superfície elevada). A dispersão do enchimento também tem um papel importante no reforço.

NUNES et al ${ }^{(38)}$ também estudaram a incorporação de cinzas de cascas de arroz em composições de borracha natural e observaram neste estudo que a adição das cinzas das cascas do arroz às composições em comparação com cargas convencionais como o negro de fumo e sílica, aumentou a velocidade 
de reticulação e diminuiu a energia de ativação.

Segundo DORMAGEN et al ${ }^{(39)}$ há um efeito negativo de compostos metálicos na degradação termooxidativa da borracha do poliisopreno e do estireno-butadieno (SBR) e avaliaram o efeito da borracha natural durante a produção da borracha vulcanizada. Residuos de íons metálicos de Fe e Cu são incorporados inevitavelmente nos compostos durante o processo de vulcanização.

SOUZA et al ${ }^{(40)}$ estudaram a influência de parâmetros de mistura em misturador aberto, os quais analisaram: a diferença de velocidade dos cilindros, a razão de fricção entre os mesmos e a quantidade de massa do composto. Algumas das características dos compostos de borracha natural, como dureza, tempo de vulcanização e $\tan \delta$, não apresentaram diferenças significativas. Foi verificado que para um composto com maior quantidade de massa obteve-se um valor de viscosidade Mooney um pouco maior do que nas composições de menor massa, fato esse que pode estar relacionado a uma menor plastificação do composto, devido a um menor cisalhamento sofrido pelo mesmo.

NUNES et al ${ }^{(41)}$ observaram que a adição crescente de mica provocou o decréscimo gradual da $\tan \delta$ das composições NR/mica, em relação à NR goma. Este resultado é conseqüência do aumento do módulo elástico das composições de NR com a incorporação da carga, uma vez que a $\tan \delta$ é a relação entre módulos viscoso $\left(E^{\prime \prime}\right)$ e elástico $\left(E^{\prime \prime}\right)$.

Este trabalho verificou a carência de estudos especificamente voltados para avaliar as propriedades tecnológicas tanto antes da formulação de 
compostos de borracha natural como após seu processamento final na forma de um produto utilizando os clones GT 1, IAN 873, PB 235 e RRIM 600. Neste contexto este trabalho vem acrescentar na literatura o estudo do comportamento térmico e mecânico dos compostos de borracha natural, avaliando e buscando uma melhoria da qualidade do látex e da borracha natural, ressaltando que foram encontrados resultados inéditos aos encontrados na literatura. 
A finalidade deste trabalho foi investigar o desempenho mecânico e térmico de compostos de borracha natural de diferentes clones, sendo que foram enfatizados os seguintes aspectos:

- Caracterização do látex e da borracha natural de diferentes clones pelos ensaios padrões de conteúdo de borracha seca, plasticidade Wallace, viscosidade Mooney, \% de cinzas, extrato acetônico e \% de nitrogênio;

- Formulação e processamento de compostos com borracha natural de diferentes clones;

- Avaliação do desempenho mecânico e térmico dos compostos de borracha natural dos diferentes clones por Calorimetria Diferencial de Varredura (DSC), Análise Termogravimétrica (TGA), propriedades mecânicas, de tração e dureza, caracterização por Análise Térmica-Dinâmico-Mecânica (DMTA), Microscopia Eletrônica de Varredura (MEV) e Espectroscopia no Infravermelho com Transformada de Fourier (FTIR). 


\section{PROCEDIMENTO EXPERIMENTAL}

Neste trabalho foram utilizadas amostras de látex de borracha natural de quatro clones recomendados para o plantio em larga escala no estado de São Paulo (GT 1, IAN 873, PB 235 e RRIM 600), em experimento instalado no municipio de Votuporanga/SP. Esse experimento faz parte de um projeto do IAC que já vem estudando as características agronômicas (fisiologia, fitotecnia e genética) da seringueira.

A borracha natural comercial utilizada foi do tipo GEB 1 (borracha obtida a partir de coagulados diversos, Granulado-Escuro-Brasileiro), fornecida pela Indústria Top Color.

A blenda foi processada utilizando $25 \%$ de massa de cada clone (GT 1 , IAN 873, PB 235 e RRIM 600), para um estudo mais próximo das condições utilizadas nas indústrias, as quais utilizam blendas de clones. Esta blenda foi homogeneizada por cerca de 5 minutos em cilindro, depois guardadas em temperatura ambiente.

\subsection{Dados Climáticos}

No dia da coleta dos látices a temperatura média do ar era de $29^{\circ} \mathrm{C}$, a do solo a $3 \mathrm{~cm}$ era de $30^{\circ} \mathrm{C}$. Estes dados climáticos foram obtidos na Estação Experimental do IAC, em Votuporanga/SP.

Nesta região predomina, o clima com estação seca definida, temperatura média anual de $22^{\circ} \mathrm{C}$, intervalo médio de $18,4^{\circ} \mathrm{C}$ a $23,9^{\circ} \mathrm{C}$, umidade relativa 
média anual em torno de $70,0 \%$ com extremos de $77,1 \%$ em fevereiro e $59,0 \%$ em agosto. A pluviosidade média anual é em torno de $1344 \mathrm{~mm}$, com regime tropical, sendo $74 \%$ de outubro a março e $26 \%$ de abril a setembro.

\subsection{Coleta do LÁteX}

As sangrias foram realizadas em 254 árvores de quatro clones (GT 1, IAN 873, PB 235 e RRIM 600), que possuem circunferência do caule igual ou superior a $45 \mathrm{~cm}$ a $1,20 \mathrm{~m}$ de altura do calo de enxertia, instalados em janeiro de 1989 na Estação Experimental do IAC, em Votuporanga/SP. Na Figura 6, observa-se a foto ilustrativa da coleta do látex.

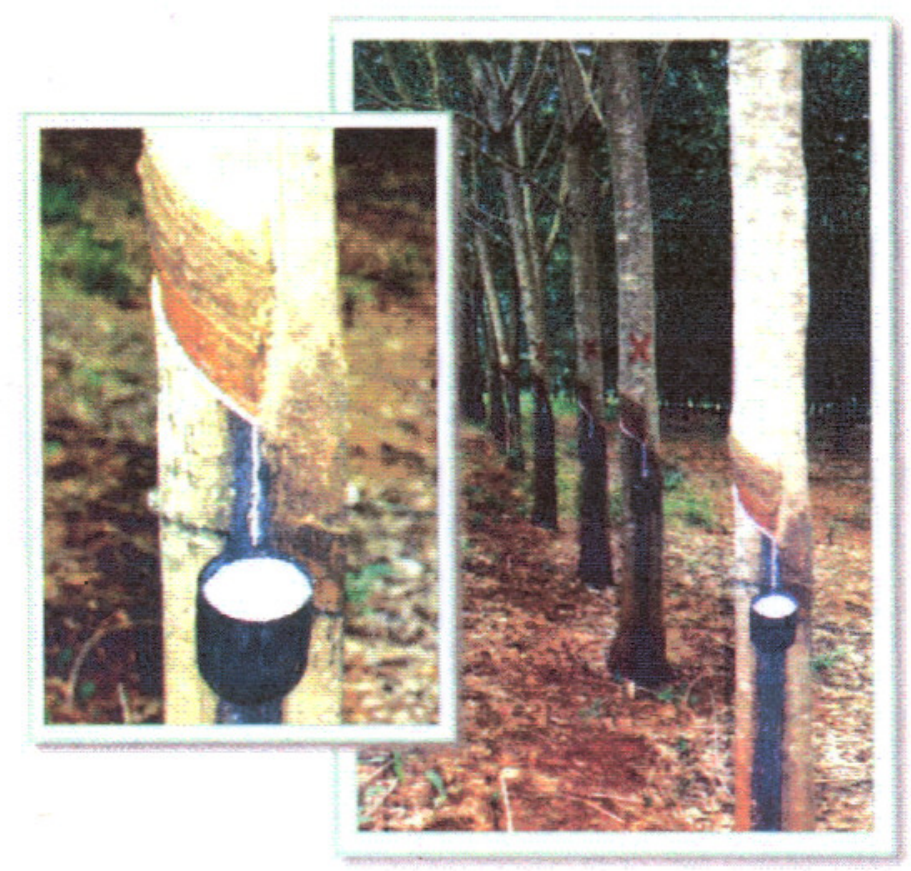

Figura 6. Foto ilustrativa da coleta do látex. Fonte: Borrachas Quirino.

As árvores foram plantadas com espaçamento de $7,0 \mathrm{~m}$ entre linhas e de $3,0 \mathrm{~m}$ entre plantas, conforme a Figura 7 , e todas foram sangradas com 0 
sistema $1 / 2 \mathrm{~S} d / 46 \mathrm{~d} / 7$ (corte em meia espiral, sangradas quatro vezes por semana, estimuladas com Ethrel) por pincelamento do painel de sangria a cada 45 dias. A estimulação com Ethrel resulta entre 20 e $100 \%$ de aumento na produção e diminui o DRC de uma quantidade de 2 a $7 \%{ }^{(31)}$.

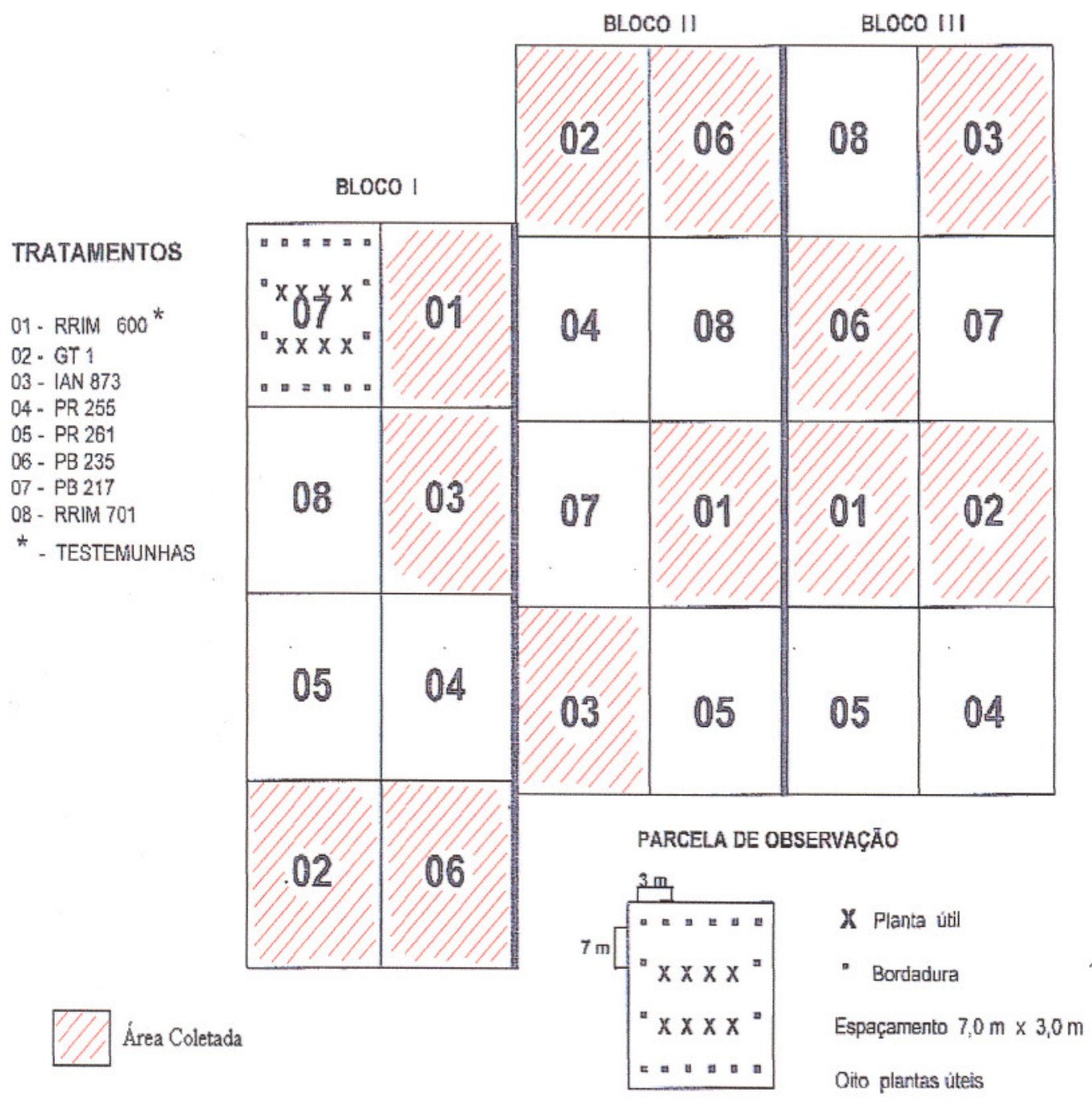

Figura 7. Experimento de avaliação de clones em grande escala de Votuporanga. 
A coleta deu-se em um único dia, para evitar diferenças nos ensaios padrões e para se obter um volume de látex suficiente para a confecção da formulação dos compostos de borracha natural.

\subsection{ESTABiLIZAÇÃo do LÁTEX}

Logo após a coleta do látex deu-se início ao processo de estabilização do mesmo. O agente utilizado foi uma solução de amônia na quantidade suficiente para elevar o $\mathrm{pH}$ do látex a $10,2(4,7 \mathrm{~mL} \mathrm{NH} 4 \mathrm{OH}$ para cada $100 \mathrm{~mL}$ de látex). Esta estabilização é realizada para que não haja coagulação do látex após a coleta do mesmo ${ }^{(26)}$.

\subsection{Coagulação do LÁteX}

Para uma completa coagulação do látex adicionou-se uma quantidade suficiente de ácido acético $3 \mathrm{~N}$ nos látices e depois de coagulado adicionou-se água para retirar todo o excesso do ácido acético, durante seis dias, trocando a água diariamente. As mantas dos látices foram passadas na calandra para retirada do excesso de água, depois foram levadas para a capela para uma primeira secagem, por um dia. Após esse tempo foram levadas para a estufa a uma temperatura de aproximadamente $50{ }^{\circ} \mathrm{C}$, por três dias. Após esse tempo as amostras foram passadas novamente na calandra por cinco vezes para uma homogeneização completa e levadas a uma temperatura de aproximadamente $50{ }^{\circ} \mathrm{C}$. Depois de retiradas da estufa foram armazenadas a temperatura ambiente ${ }^{(26)}$. 


\subsection{ANÁlises de ROTINA NO LÁTEX}

Os ensaios padrões (\% de cinzas, \% de nitrogênio, extrato acetônico, viscosidade Mooney, plasticidade Wallace e PRI) foram realizados conforme a norma NBR $11597 / 96^{(41)}$. As análises de \% de cinzas, \% de nitrogênio, extrato acetônico e viscosidade foram realizadas em duplicatas.

\subsubsection{DETERMINAÇÃo DO TEOR DE CINZAS}

O teor de cinzas reduz a borracha a somente compostos inorgânicos não decompostos à temperatura de aproximadamente $570 \pm 25^{\circ} \mathrm{C}$, enquanto todas as substâncias de natureza orgânica são destruídas nessa temperatura; o excesso de cinzas além de poder reduzir as propriedades dinâmicas do vulcanizado, tem grande possibilidade de provocar efeito depressivo nas propriedades de envelhecimento. Pesou-se $5 \mathrm{~g}$ de borracha picotada e que foi colocada em cadinho de porcelana, previamente calcinado por 30 minutos a $570 \pm 25^{\circ} \mathrm{C}$, e levadas ao forno tipo Mufla para completa calcinação. No final determina-se a massa de cinzas residuais nos cadinhos e calcula-se a $\%$ de $\operatorname{cinzas}^{(42)}$.

\subsubsection{DETERMINAÇÃO DO EXTRATO ACETÔNICO}

Esse é representado pela fração não-borracha solúvel em acetona, tendo como principais componentes os ácidos graxos, ésteres de esteróis, em adição a um número de outras substâncias de menor importância, sendo que os altos valores de extrato acetônico influenciam negativamente nas características 
físicas de um produto acabado. Uma massa de cerca de $2 \mathrm{~g}$ com aproximação de 0,1 mg é adicionada em um extrator tipo Soxhlet e a extração com acetona é feita com acetona por 16 horas seguidas. A acetona é removida por evaporação em banho-maria e o extrato seco é pesado para a determinação da porcentagem em borracha seca ${ }^{(42)}$.

\subsubsection{DeterminaÇÃo do TEOR de NITROgênio (MÉtodo SEMIMICRo KJELDAHAL)}

A análise de nitrogênio foi realizada no laboratório de química do CPPSE/Embrapa, de acordo com o método da ABNT.

O conteúdo de nitrogênio combinado ${ }^{(42)}$ na borracha é um fator muito importante. Ele expressa o excesso ou a deficiência de substâncias nitrogenadas que afetam, depois que a borracha é processada e vulcanizada, as propriedades de resistência do produto obtido. Cerca de $200 \mathrm{mg}$ de borracha são pesados e misturados com mistura catalítica para digestão (1:10 $\mathrm{K}_{2} \mathrm{SO}_{4}$ ou $\mathrm{Na}_{2} \mathrm{SO}_{4}+\mathrm{H}_{2} \mathrm{SO}_{4}$ concentrado). Após a obtenção da digestão da borracha, o digerido é levado ao equipamento Kjeltec auto 1035/38 e inicia-se a destilação. A destilação é feita por arraste a vapor. $\mathrm{O}\left(\mathrm{NH}_{4}\right)_{2} \mathrm{SO}_{4}$ é tratado com solução de $\mathrm{NaOH} 40 \%$ em excesso, ocorrendo a liberação da $\mathrm{NH}_{3}$ gasoso. $\mathrm{A} \mathrm{NH}_{3}$ é recebida e reage com $\mathrm{H}_{3} \mathrm{BO}_{3}$ + indicador. $\mathrm{O}$ borato ácido de amônio formado é titulado com solução de $\mathrm{H}_{2} \mathrm{SO}_{4} 0,1 \mathrm{~N}$. O equipamento calcula a \% de proteína bruta (PB) que fornecerá a \% de nitrogênio, a partir da expressão:

$$
\% \text { de nitrogênio }=\frac{\% P B}{6,25}
$$




\subsubsection{VISCOSIDADE MOONEY $\left(\mathrm{V}_{\mathrm{R}}\right)$}

A viscosidade Mooney $\left(V_{R}\right)$ é medida através de um disco metálico envolto por uma amostra de borracha, contido numa câmara rígida mantida a temperatura constante de $100 \pm 0,5^{\circ} \mathrm{C}$. $\mathrm{O}$ disco é girado lentamente em uma direção, pelo viscosimetro, durante um tempo de 4 minutos. A resistência oferecida pela borracha a esta rotação, medida em uma escala convencionada, é definida como a viscosidade Mooney do corpo de prova. Para cada determinação preparou-se 2 corpos de prova com cerca de $50 \mathrm{~mm}$ de diâmetro e $6 \mathrm{~mm}$ de espessura com um furo central de $8 \mathrm{~mm}^{(42)}$.

\subsubsection{Plasticidade Wallace $\left(P_{0}\right)$}

As análises de viscosidade Mooney e plasticidade Wallace foram realizadas no Instituto de Pesquisas Tecnológicas (IPT), segundo as normas descritas na ABNT.

O plastímetro Wallace de pratos paralelos mede a plasticidade com fundamento no achatamento de um corpo de prova submetido a uma compressão constante em condições padrão de temperatura, tempo de ação da força de compressão, forma e peso do corpo de prova ${ }^{(42)}$.

A leitura é feita em unidades de escala Wallace. Pesou-se cerca de $30 \mathrm{~g}$ de borracha seca que foi passada no cilindro e resultou em um filme de $1,7 \mathrm{~mm}$ de espessura, aproximadamente. Preparou-se 10 corpos de prova que foram divididos, ao acaso, em dois grupos de cinco cada um. A plasticidade $\left(\mathrm{P}_{\mathrm{o}}\right)$ foi determinada em 5 corpos de prova não degradados e em 5 termodegradados 
$\left(140^{\circ} \mathrm{C}\right.$ por 30 minutos) usando um plastímetro Wallace. $O$ índice de retenção de plasticidade (PRI) é expresso em porcentagem e calculado por:

$$
P R I=\left(P_{30} / P_{0}\right) \times 100
$$

onde $\mathrm{P}_{0}=$ plasticidade e $\mathrm{P}_{30}=$ plasticidade após degradação térmica dos corpos de prova.

\subsection{Preparação dos compostos}

Uma peça de borracha, ao contrário do que normalmente ocorre em plásticos, é constituída não só de borracha, mas também de uma série de produtos incorporados na mistura sob a forma de aditivos, precisando ter uma formulação. Foi utilizado como antioxidante o Banox. Os aceleradores utilizados foram 2,2'-dissulfeto de benzoatiazil (MBTS) e o dissulfeto de tetrametiltiuram (TMTD) e os demais aditivos, óxido de zinco (ativador), ácido esteárico (co-ativador), óleo de processamento (plastificante) e enxofre (agente de vulcanização) foram fornecidos pela indústria Top Color. Todos os aditivos foram utilizados conforme recebidos.

A indústria de artefatos de borracha para montar uma formulação, geralmente utiliza as quantidades de ingredientes em função de cem partes de borracha, utilizando a sigla phr, do inglês "per hundred of rubber".

A formulação básica dos compostos de borracha natural ${ }^{(44,45)}$, utilizada está indicada na Tabela 1. 
Tabela 1. Composição dos compostos de borracha natural.

\begin{tabular}{lc}
\hline \multicolumn{1}{c}{ Componentes } & Quantidade (phr) \\
\hline Borracha Natural & 100 \\
Ácido Esteárico & 2 \\
Óxido de Zinco & 5 \\
Antioxidante & 1 \\
Negro de Fumo N330 & 30 \\
Óleo de Processamento & 5 \\
M.B.T.S. & 2 \\
T.M.T.D. ${ }^{* *}$ & 1 \\
Enxofre & 2,5 \\
\hline
\end{tabular}

*2,2'-dissulfeto de benzoatiazil ** dissulfeto de tetrametiltiuram

O processamento foi realizado em um cilindro da marca Parabor modelo EQ-ML, instalado na Embrapa. As condições de processamento foram: temperatura de $70^{\circ} \mathrm{C}$, velocidade de rotação de $75 \mathrm{rpm}$ e tempo de mistura de 15 minutos. Após vinte e quatro horas, realizou-se a vulcanização em temperatura de aproximadamente $145^{\circ} \mathrm{C}$ e uma pressão de aproximadamente $4 \mathrm{MPa}$, em uma prensa Schwing Siwa em três diferentes condições: durante 5, 7 e 9 minutos.

O plastificante, neste caso o óleo de processamento, possui uma coloração escura, devido ao alto teor de aromáticos. Sua incorporação à mistura nem sempre é fácil, devido ao fato do misturador ser aberto ${ }^{(45)}$. 


\subsection{ANÁLISES TÉRMICAS}

As análises térmicas (DSC, TGA e DMTA) e os espectros na região do infravermelho foram realizadas no Departamento de Física, Química e Biologia da UNESP/Presidente Prudente, com a colaboração do Dr. Aldo E. Job.

\subsubsection{ANÁLISE TERMO-DINÂMICO-MECÂNICA (DMTA)}

As amostras foram analisadas em um equipamento marca NETZSCH modelo DMTA 242C, no modo de tensão de tração, equipado com controlador TASC 414/3A e sistema de resfriamento por suprimento de nitrogênio líquido CC 200, sendo a deformação máxima aplicada de 0,025\% com amplitude máxima de $60 \mu \mathrm{m}$ e uma força dinâmica máxima de $3,0 \mathrm{~N}$ com força estática 1,5X e força dinâmica aplicada. A taxa de aquecimento utilizada foi de $5^{\circ} \mathrm{C} / \mathrm{min}$ e o intervalo de temperatura de $-120^{\circ} \mathrm{C}$ a $180{ }^{\circ} \mathrm{C}$. A freqüência utilizada foi de

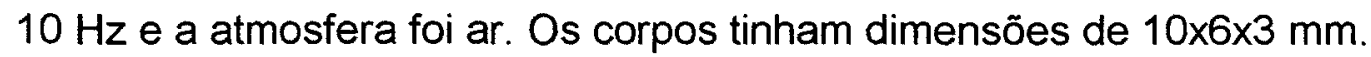

\subsubsection{Calorimetria Diferencial de VarRedura (DSC)}

Utilizou-se um instrumento marca NETZSCH modelo DSC 204 equipado com controlador TASC 414/3A e sistema de resfriamento por suprimento de nitrogênio líquido CC 200. A taxa de aquecimento utilizada foi de $10^{\circ} \mathrm{C} / \mathrm{min}$ e o intervalo de temperatura de $-120^{\circ} \mathrm{C}$ a $180^{\circ} \mathrm{C}$. Os corpos de prova continham uma massa de aproximadamente 5,0mg. 


\subsubsection{ANÁlise Termogravimétrica (TGA)}

As análises termogravimétricas foram realizadas em equipamento NETZSCH modelo TG 209, com início a temperatura ambiente até $800^{\circ} \mathrm{C}$, com taxa de aquecimento de $10{ }^{\circ} \mathrm{C} / \mathrm{min}$, com nitrogênio como gás de arraste com fluxo de $15 \mathrm{~mL} / \mathrm{min}$.

\subsection{INFRAVERMELHO (FTIR)}

As amostras com dimensões de $50 \times 50 \times 3 \mathrm{~mm}$ foram analisadas por Refletância Total Atenuada (FTIR/ATR) em um infravermelho marca Bruker modelo Vector22.

\subsection{Microscopia Eletrônica de VARREduRA (MEV)}

A microscopia eletrônica de varredura (MEV) foi realizada no Instituto de Física de São Carlos - IFSC/USP. Utilizou-se um microscópio eletrônico marca ZEISS modelo DSM 960, com feixe de elétrons de $20 \mathrm{kV}$ e ampliações de 5000x, utilizando detector de elétrons retroespalhados. As amostras foram quebradas após imersão em nitrogênio líquido a fim de se analisar a fratura frágil, em seguida foram colocadas sobre suporte de alumínio e fixadas nas bordas com tinta prata ${ }^{(28)}$. Sobre as amostras depositou-se uma camada de $20 \mathrm{~nm}$ de ouro "sputter coater" (plasma de argônio) marca BALZERS modelo $\operatorname{SCD} 50$ 


\subsection{EnSAios de TRAção}

Os ensaios de tração foram realizados no Departamento de Engenharia de Materiais da Universidade Federal de São Carlos (DEMa). Usou-se equipamento marca INSTRON. Os ensaios foram realizados segundo a ASTM D 412 - 97 Método A. A velocidade utilizada foi de $500 \mathrm{~mm} / \mathrm{min}$ com célula de carga de $500 \mathrm{~N}$.

\subsection{DUREZA}

A dureza foi determinada em durômetro do tipo Shore A, segundo a norma ASTM D-2240-97. Foram feitas 5 medidas para cada composição e os resultados foram as medianas dos valores parciais. 


\section{RESULTADOS E DISCUSSÕES}

\subsection{ENSAIOS PADRÖES}

A matéria orgânica decomposta no solo, contém quantidades variáveis de elementos minerais, como o N $, \mathrm{P}, \mathrm{Mg}, \mathrm{Ca}, \mathrm{S}$, e micronutrientes. Esta matéria orgânica, a medida que se decompõe, libera os nutrientes, tornando-se disponíveis às plantas, inclusive no látex produzido pela seringueira, o que pode ser avaliado pela medida do teor de cinzas obtido, como pode ser visto na Tabela 2, juntamente com a média calculada. A média calculada dos valores dos 4 clones foi obtida pela equação:

$$
\overline{\mathrm{x}}_{\text {calculada }}=\frac{\text { valor } G T+\text { valorI } A N+\text { valorPB+valor } R R I M}{4}
$$

Tabela 2. Valores médios obtidos para o teor de cinzas das amostras de borracha natural.

\begin{tabular}{lccc}
\hline \multicolumn{1}{c}{ Clone } & \%Cinzas & s & C.V. (\%) \\
\hline Blenda & 0,142 & 0,012 & 8,50 \\
Comercial & 0,375 & 0,012 & 3,20 \\
GT 1 & 0,116 & 0,026 & 22,5 \\
IAN 873 & 0,115 & 0,011 & 9,80 \\
PB 235 & 0,134 & 0,033 & 25,3 \\
RRIM 600 & 0,121 & 0,051 & 42,2 \\
$\bar{x}_{\text {calculada }}$ & 0,123 & - & - \\
\hline
\end{tabular}

Os valores de porcentagens de cinzas encontrados na literatura estão na faixa de 0,1 a $0,9 \%^{(42)}$. Os resultados do teor de cinzas obtidos para os clones 
foram menores que os presentes na borracha comercial, provavelmente, pelo fato de termos uma menor quantidade de impurezas na borracha, devido as condições da coleta e processamento dos látices dos clones, que evitou-se o contato com estas impurezas, que podem provir de folhas, galhos, poeira, etc. Essa característica também depende muito dos fatores ambientais e genéticos intrínsecos aos clones ${ }^{(46)}$ representando os constituintes inorgânicos presentes na borracha.

Dos resultados obtidos para as amostras, e o valor médio calculado, não excederam o limite máximo de $0,5 \%$ de cinzas, valor máximo recomendado pelo $\mathrm{SMR}^{(46)}$ para borrachas de boa qualidade. O clone RRIM 600 foi o que apresentou resultados mais próximos da média calculada.

O extrato acetônico é representado pela fração solúvel em acetona, como ácidos graxos superiores e outras substâncias, como carboidratos e proteinas. A Tabela 3 mostra valores médios do extrato acetônico das amostras e a média calculada.

Tabela 3.Valores médios obtidos para o extrato acetônico (EA) das amostras de borracha natural.

\begin{tabular}{lccc}
\hline \multicolumn{1}{c}{ Clone } & EA & s & C.V. (\%) \\
\hline Blenda & 2,93 & 0,012 & 0,41 \\
Comercial & 1,99 & 0,012 & 0,60 \\
GT 1 & 2,44 & 0,026 & 1,10 \\
IAN 873 & 2,34 & 0,011 & 0,48 \\
PB 235 & 4,08 & 0,034 & 0,80 \\
RRIM 600 & 2,54 & 0,051 & 2,00 \\
$\bar{X}_{\text {calculada }}$ & 2,85 & - & - \\
\hline
\end{tabular}


A porcentagem de extrato acetônico, não pode ultrapassar $3,5 \%$. O clone PB 235 está, nitidamente, em um patamar superior no valor de extrato acetônico, tendo o maior valor médio e a borracha comercial o menor valor médio pouco abaixo dos limites estabelecidos, mas ficando dentro do erro experimental. A média calculada ficou bem próxima do valor obtido para a blenda.

O teor de nitrogênio é muito importante, porque se houver excesso de substâncias nitrogenadas a borracha apresentará depois de processada e vulcanizada, propriedades de resistência mecânica insatisfatórias. A deficiência destas substâncias nitrogenadas é também indesejável, pois neste caso a borracha poderá também exibir propriedades dinâmicas insatisfatórias. A Tabela 4, lista os valores médios das amostras estudadas e a média calculada.

Tabela 4. Valores médios obtidos para o teor nitrogênio das amostras de borracha natural.

\begin{tabular}{lccc}
\hline \multicolumn{1}{c}{ Clone } & \%N & s & C.V. (\%) \\
\hline Blenda & 0,47 & 0 & 0 \\
Comercial & 0,20 & 0,014 & 7,10 \\
GT 1 & 0,47 & 0,042 & 9,00 \\
IAN 873 & 0,49 & 0,021 & 4,30 \\
PB 235 & 0,49 & 0,021 & 4,30 \\
RRIM 600 & 0,61 & 0,007 & 1,15 \\
$\bar{x}_{\text {calculada }}$ & 0,52 & - & - \\
\hline
\end{tabular}

As borrachas de boa qualidade devem exibir teores de $\mathrm{N}$ entre 0,2 e $0,6 \%{ }^{(5,48)}$. Dos resultados de \% de nitrogênio observa-se que o clone RRIM 600 
possui a maior \% de $\mathrm{N}$ médio, sendo que os valores médios das amostras estão dentro dos teores exigidos, pois o RRIM 600 apresentou um teor bem próximo do exigido, dentro da faixa de erro experimental. Os resultados obtidos para os clones IAN 873, PB 235 estão bem próximos ao valor da média calculada, já a blenda apresentou um valor abaixo da média calculada, este está abaixo de $0,6 \%$ que caracteriza o teor máximo para uma borracha dentro dos padrões de qualidade, segundo o SMR (Standard Malaysian Rubber) ${ }^{(47)}$.

O viscosímetro Mooney é usado principalmente para medir e checar o grau da estabilização da viscosidade em borrachas. Na Tabela 5 estão listados os valores da viscosidade Mooney para as amostras de borracha natural crua.

Tabela 5. Valores médios obtidos para a viscosidade Mooney das amostras de borracha natural.

\begin{tabular}{lccc}
\hline \multicolumn{1}{c}{ Clone } & $\mathrm{V}_{\mathbf{R}}$ & $\mathbf{s}$ & C.V. (\%) \\
\hline Blenda & 82,6 & 0 & 0 \\
Comercial & 96,3 & 0,14 & 0,15 \\
GT 1 & 82,1 & 0 & 0 \\
IAN 873 & 91,3 & 0,57 & 0,62 \\
PB 235 & 86,0 & 0,14 & 0,16 \\
RRIM 600 & 77,4 & 0,92 & 1,20 \\
$\bar{X}_{\text {calculada }}$ & 84,2 & - & - \\
\hline
\end{tabular}

Dos resultados de viscosidade Mooney verifica-se que os clones GT 1 e RRIM 600 possuem os menores valores e a borracha comercial o maior valor. O clone RRIM 600 apresentou neste ensaio um valor abaixo da média 
calculada. $A V_{R}$ varia de clone para clone, devido a maior ou menor quantidade de constituintes não borracha que influenciam nas características da borracha, como por exemplo na formação de ligações cruzadas. Essas borrachas quando estocadas em condições de temperatura e umidade ambientes tendem a aumentar a quantidade de ligações cruzadas, ocasionando um aumento adicional da $V_{R}$, sendo um dos motivos da borracha comercial possuir um maior valor de $V_{R}$, pois deve ter tido um maior tempo de estocagem no processo industrial. No trabalho de BURFIELD e GAN ${ }^{(49)}$ a presença de grupos epóxido e amino na borracha foi demonstrada. O número de tais grupos é variável de clone para clone e sabe-se que ocorre uma diminuição do número desses grupos na estocagem, ao passo que ocorre um aumento da plasticidade e viscosidade da borracha.

A plasticidade Wallace $\left(P_{0}\right)$ está ligada ao comprimento da cadeia do poliisopreno, sendo uma medida do estado de degradação da borracha ${ }^{(49,50,51,52)}$. Ela pode variar de clone para clone, e também entre as coletas. O plastímetro Wallace é usado para medir o índice de retenção de plasticidade (PRI) e a plasticidade Wallace $\left(\mathrm{P}_{0}\right)$. A plasticidade está ligada com o comprimento da cadeia do poliisopreno, sendo que o PRI é uma medida do estado de degradação da borracha ${ }^{(54)}$. Na Tabela 6, observa-se os valores da plasticidade e PRI para as amostras. 
Tabela 6. Valores médios de plasticidade e PRI das amostras de borracha natural.

\begin{tabular}{lcccccc}
\hline Amostra & $\mathbf{P}_{\mathbf{0}}$ & $\mathbf{s}$ & C.V.(\%) & PRI & s & C.V.(\%) \\
\hline Blenda & 45 & 0,55 & 1,20 & 63 & 5,8 & 9,30 \\
Comercial & 48 & 0,71 & 1,50 & 52 & 3,1 & 5,90 \\
GT 1 & 49 & 0,71 & 1,40 & 60 & 2,4 & 4,10 \\
IAN 873 & 52 & 0,45 & 0,90 & 64 & 2,8 & 4,30 \\
PB 235 & 50 & 0,45 & 0,90 & 71 & 3,2 & 4,50 \\
RRIM 600 & 46 & 0,45 & 1,00 & 73 & 1,1 & 1,50 \\
$\bar{X}_{\text {calculada }}$ & 49 & - & - & 67 & - & - \\
\hline
\end{tabular}

Assim, em média, os resultados indicam que o clone IAN 873 é o que deve estar associado a uma estrutura de cadeias poliméricas maiores e/ou com maior intercruzamento, por possuir o maior valor médio da $\mathrm{Po}_{0}$. No entanto, todos os clones possuem $\mathrm{P}_{0}$ acima de 30 unidades, abaixo do qual, as borrachas seriam consideradas muito moles.

Assim, de acordo com a literatura ${ }^{(50)}$ as variações do PRI nas borrachas dos 4 clones estudados são influenciadas pelas diferenças genéticas clonais e alterações nas condições climáticas que atuam diretamente na síntese dos constituintes não borracha do látex obtido entre as coletas, principalmente os tocoferóis, apresentando uma forte ação antioxidante na borracha. Altos valores de PRI correspondem a uma boa resistência ao aquecimento, que leva a degradação termo-oxidativa. As especificações do $\mathrm{SMR}^{(47)}$ padronizam o valor 
de $60 \%$ como um mínimo necessário, para todas as classes de borrachas notase que o resultado médio da borracha comercial ficou um pouco abaixo da média $(52 \%)$ demonstrando ser de qualidade um pouco inferior em relação as amostras dos clones, sendo que, a média calculada resultou valores acima do mínimo necessário.

A plasticidade e viscosidade da borracha são de extrema importância, já que a mesma só pode ser devidamente processada quando são adicionados os diversos ingredientes para vulcanizar e promover as propriedades desejadas no artigo a ser fabricado. As borrachas excessivamente duras, com elevados valores de plasticidade na escala Mooney ou Wallace ${ }^{(53)}$, nem sempre são as preferidas, já que elas consomem excesso de mão-de-obra, tempo e energia por ocasião do processamento.

Os lipídios associados à borracha podem atuar como plastificantes internos, sendo que, alto valor do extrato acetônico com consideráveis quantidades de lipídios pode induzir baixos valores de $P_{0}$ e $V_{R}{ }^{(55)}$. $O$ clone $P B$ 235 está em um patamar superior nos valores de extrato acetônico e valores medianos para $P_{0} \in V_{R}$, provavelmente devido, a maior quantidade de lipídios que atuam como plastificantes internos ${ }^{(54)}$. Já as amostras IAN 873 e a borracha comercial possuem os menores valores médios do extrato acetônico e os maiores valores da $P_{0}$ e $V_{R}$.

As propriedades $P_{0}$ e $V_{R}$, aparentemente, não apresentam um padrão definido de comportamento frente às variações climáticas e as variações 
fenológicas da planta (queda de folhas, refolhamento, florescimento e frutificação) $)^{(31)}$.

\subsection{ANÁLISE TÉRMICA}

A temperatura de transição vítrea $(\mathrm{Tg})$ refere-se ao intervalo de temperatura na qual o material polimérico muda de um estado vítreo (mais rígido) para um estado mais borrachoso (elastomérico). Abaixo da faixa de transição há relativamente pouca movimentação molecular e os segmentos da cadeia estão como que congelados, sendo capazes de vibrar nessas posições fixas, mas com poucas chances de rearranjos nas posições. Aumentando-se a temperatura, a amplitude das vibrações torna-se maior e é possivel a movimentação ocasional de segmentos da cadeia. Quanto mais flexível a cadeia, mais baixa a temperatura na qual isto irá ocorrer ${ }^{(56)}$. A Tg obtida através da técnica de calorimetria diferencial de varredura (DSC) é acompanhada de uma mudança na capacidade de calor, mas não há mudança de entalpia $(\mathrm{AH}=0)$. A transição aparece, portanto, como uma descontinuidade na linha de base ${ }^{(57)}$.

Estudos envolvendo as propriedades dinâmico-mecânicas da borracha natural vulcanizada ${ }^{(34)}$ sugerem que mudanças significativas na $\mathrm{Tg}$ podem ser decorrência da formação de grupos heterocíclicos ao longo da cadeia elastomérica. Este fenômeno contribui para uma redução da mobilidade molecular da cadeia polimérica. As diferenças nos valores da $\mathrm{Tg}$ encontradas neste estudo não devem ser atribuídas apenas as diferenças no grau de 
reticulação, mas também a outras interaçõs de cunho intra ou intermolecular, que podem variar de acordo com o sistema de vulcanização empregado.

As temperaturas de transição vitrea $(\mathrm{Tg})$ obtidas através do DMTA, foram medidas nos pontos máximos das curvas do fator de amortecimento em função da temperatura, e as de DSC através da primeira derivada da curva, como mostrado na Figura 16, e os valores da Tg encontrados pelas técnicas de DSC e DMTA, para as amostras de borracha natural crua e dos compostos encontram-se na Tabela 7 e 8 respectivamente.

Tabela 7. Valores da Tg para as amostras de borracha natural crua, através das técnicas de DSC e DMTA.

\begin{tabular}{ccc}
\hline & \multicolumn{2}{c}{$\left.\operatorname{Tg}^{\circ} \mathrm{C}\right)$} \\
\hline Amostras & DMTA & DSC \\
\hline Blenda & $-92,5$ & $-63,2$ \\
Comercial & $-69,5$ & $-62,6$ \\
GT 1 & $-78,8$ & $-62,5$ \\
IAN 873 & $-66,0$ & $-62,5$ \\
PB 235 & $-75,0$ & $-62,6$ \\
RRIM 600 & $-74,5$ & $-62,0$ \\
$\bar{X}_{\text {calculada }}$ & $-73,6$ & $-62,4$ \\
\hline
\end{tabular}

Os valores das temperaturas de transição vítrea ( $\mathrm{Tg}$ ) da borracha natural crua e da borracha vulcanizada encontradas na literatura são de $-72^{\circ} \mathrm{C}$ e de $63^{\circ} \mathrm{C}{ }^{(58,59)}$, respectivamente. Há um aumento da $\mathrm{Tg}$ depois da vulcanização devido ao fato que a borracha adquire uma estrutura reticulada devido as 
macromoléculas dos compostos possuírem ligações cruzadas, pelo enxofre aumentando o valor da $\mathrm{Tg}$. As ligações cruzadas "amarram" uma cadeia à outras impedindo seu livre deslizamento (Figuras 4 e 5 ). No caso dos elastômeros vulcanizados, tem-se cadeias com baixa densidade de ligações cruzadas.

Tabela 8. Valores da Tg para as amostras de borracha natural vulcanizadas com diferentes tempos de vulcanização, através das técnicas de DSC e DMTA.

\begin{tabular}{lcccccc}
\hline \multirow{2}{*}{ Amostra } & \multicolumn{2}{c}{5 minutos } & \multicolumn{2}{c}{7 minutos } & \multicolumn{2}{c}{9 minutos } \\
& $\begin{array}{c}\mathrm{Tg}\left({ }^{\circ} \mathrm{C}\right) \\
\text { DMTA }\end{array}$ & $\mathrm{Tg}\left({ }^{\circ} \mathrm{C}\right)$ & $\mathrm{Tg}\left({ }^{\circ} \mathrm{C}\right)$ & $\mathrm{Tg}\left({ }^{\circ} \mathrm{C}\right)$ & $\mathrm{Tg}\left({ }^{\circ} \mathrm{C}\right)$ & $\mathrm{Tg}\left({ }^{\circ} \mathrm{C}\right)$ \\
\hline Blenda & $-56,5$ & $-58,4$ & $-57,0$ & $-58,3$ & $-62,4$ & $-57,2$ \\
Comercial & $-64,5$ & $-57,1$ & $-66,4$ & $-57,8$ & $-61,0$ & $-56,8$ \\
GT1 & $-60,9$ & $-58,0$ & $-58,3$ & $-58,8$ & $-62,8$ & $-57,5$ \\
IAN 873 & $-62,5$ & $-57,7$ & $-60,8$ & $-57,7$ & $-59,4$ & $-57,3$ \\
PB 235 & $-64,0$ & $-58,6$ & $-61,5$ & $-58,1$ & $-62,3$ & $-57,2$ \\
RRIM 600 & $-60,0$ & $-57,3$ & $-63,4$ & $-57,5$ & $-63,8$ & $-57,5$ \\
$\overline{\mathrm{X}}_{\text {calculada }}$ & $-61,9$ & $-57,9$ & $-61,0$ & $-58,0$ & $-62,1$ & $-57,4$ \\
\hline
\end{tabular}

As temperaturas de transição vítrea $(\mathrm{Tg})$ obtidas através da técnica de DMTA estão em um intervalo de $-56,5^{\circ} \mathrm{C}$ a $-66,4^{\circ} \mathrm{C}$, sem uma tendência clara de variação em relação ao tipo de clone nem ao tempo de vulcanização. Em relação a técnica de $\mathrm{DSC}$, o intervalo de variação é menor $-57,1^{\circ} \mathrm{C}$ a $-58,8^{\circ} \mathrm{C}$, que está dentro do erro experimental, não sendo significativa a variação. A blenda apresentou valores da Tg, tanto por DMTA quanto por DSC acima da média calculada. 


\subsubsection{ANÁLISE TÉRMICA-DINÂMICO-MECÂNICA (DMTA)}

A análise termo-dinâmico-mecânica (DMTA) permite a obtenção de vários parâmetros, sendo um deles a relação entre o módulo de perda e o de armazenamento, conhecido com tan delta, cujo valor máximo caracteriza a temperatura de transição vítrea, $\operatorname{Tg}^{(60)}$. Para todas as análises as curvas obtidas pela técnica de DMTA apresentaram uma única fase, indicando a transição vítrea, correspondente a borracha natural.

$\mathrm{Na}$ Figura 8 , encontram-se as curvas de $\tan \delta$ versus temperatura das amostras de borracha natural crua, os valores da Tg encontram-se na Tabela 7.

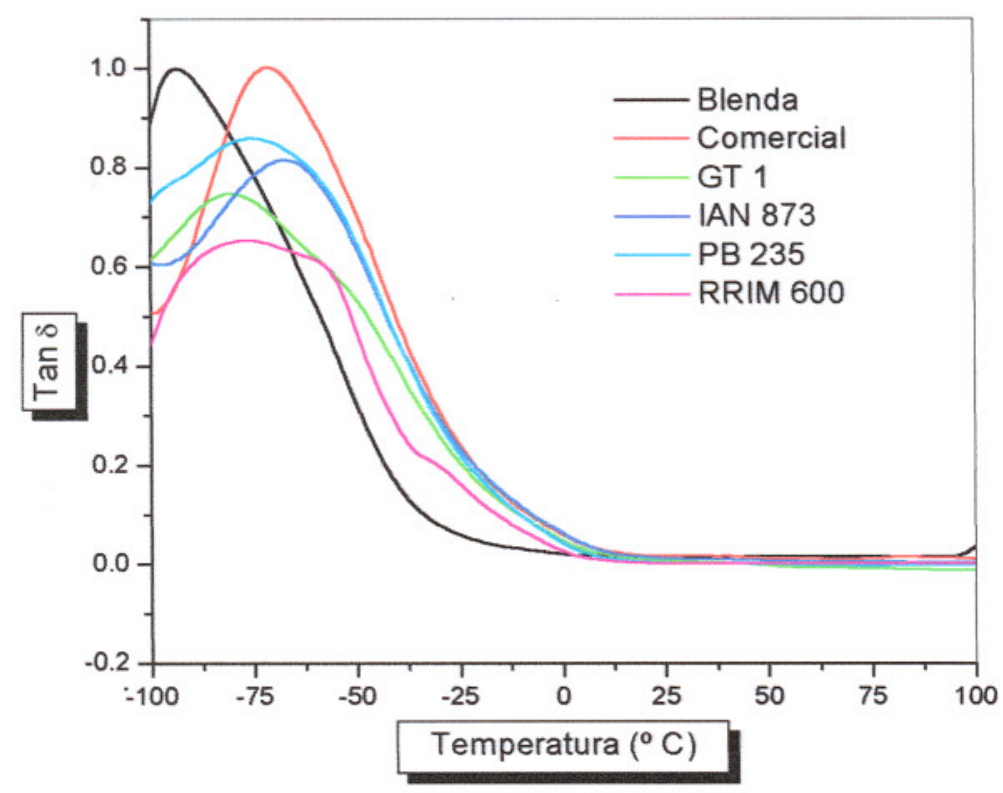

Figura 8. Curvas do fator amortecimento ( $\tan \delta$ ) versus temperatura para as amostras de borracha natural crua.

MARTINS et al ${ }^{(61)}$ verificou que a adição de celulose regenerada, que é utilizada como carga, promove um afastamento entre as cadeias macromoleculares da borracha, o que acarreta sua maior flexibilidade, e 
portanto, menor $\mathrm{Tg}$, o que não é observado para a incorporação de negro de fumo caso em que, neste estudo foi observado um aumento no valor da $\mathrm{Tg}$, comparando as Tabelas 07 e 08. Fizeram também um estudo da variação de tan delta em relação a freqüência, onde observaram que não há diferenças significativas entre os compostos, na faixa de 100 a $500 \mathrm{cpm}$.

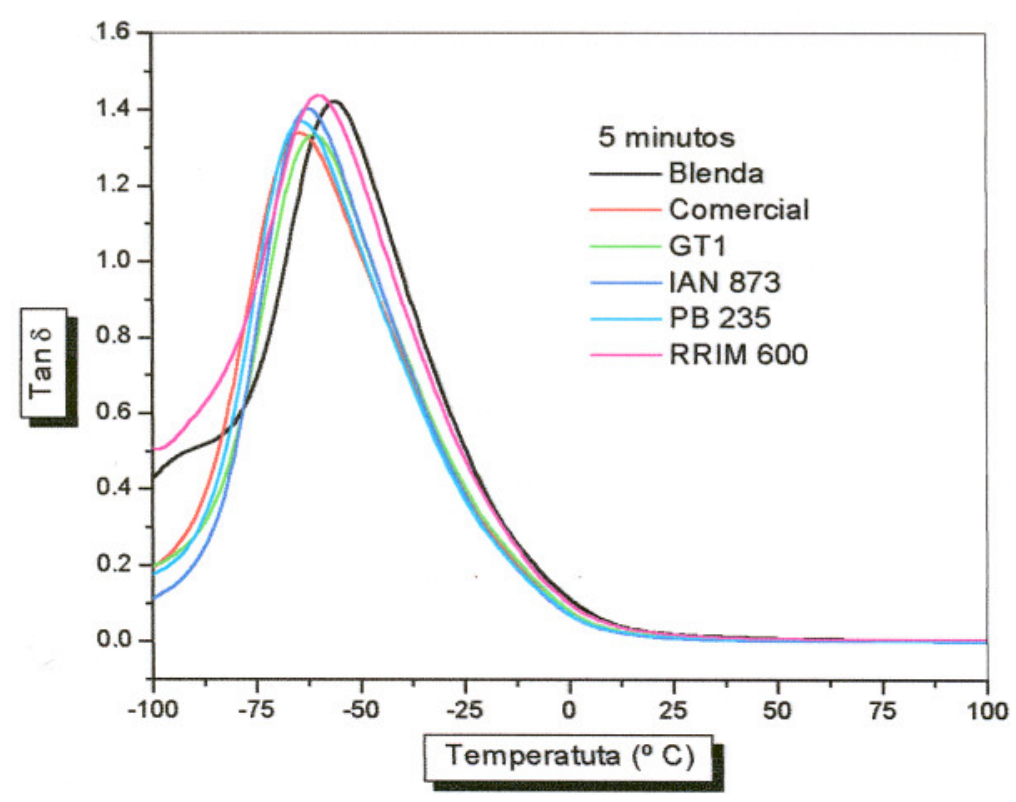

Figura 9. Curvas do fator amortecimento $(\tan \delta)$ versus temperatura dos compostos: blenda, borracha comercial, GT 1, IAN 873, PB 235 e RRIM 600 com tempo de vulcanização de 5 minutos.

Observa-se na Figura 9, que as curvas não diferem significativamente nos valores de intensidades dos máximos de $\tan \delta$ e da $\mathrm{Tg}$, em relação aos diferentes clones e mesmo tempo de vulcanização. Em relação a tan $\delta$, pode-se afirmar que o clone RRIM 600 é o que possui a maior intensidade e o clone GT 1 o menor. Os compostos da blenda e borracha comercial, apresentaram a 
maior e a menor $\operatorname{Tg}\left(-56,5\right.$ e $\left.-64,5^{\circ} \mathrm{C}\right)$, respectivamente, como observa-se na Tabela08.

Nas Figuras 01 e 02 - Anexo $A$, temos as curvas de tan $\delta$ em relação a temperatura, para os compostos vulcanizados a 7 e 9 minutos respectivamente, com isso, pode-se afirmar que os valores da Tg, como mostrado na Tabela 8 , não possuem uma tendência clara de variação, nem diferenças significativas.

Observa-se na Figura 10, que os valores de amortecimento e da $\mathrm{Tg}$ não tiveram diferenças significativas entre os tempos de vulcanização, diferenciando-se da borracha natural crua, que possui uma $\mathrm{Tg}$ menor, devido a formação de ligações cruzadas com a vulcanização com o enxofre e o efeito reforçante do negro de fumo, juntamente com os outros aditivos para vulcanizar a borracha natural. Pode ser visto que os valores de tan delta dos compostos são maiores do que os da borracha natural crua (Figura 10), o que está de acordo com o módulo elástico (E') obtido para esses compostos (Figura 13). 


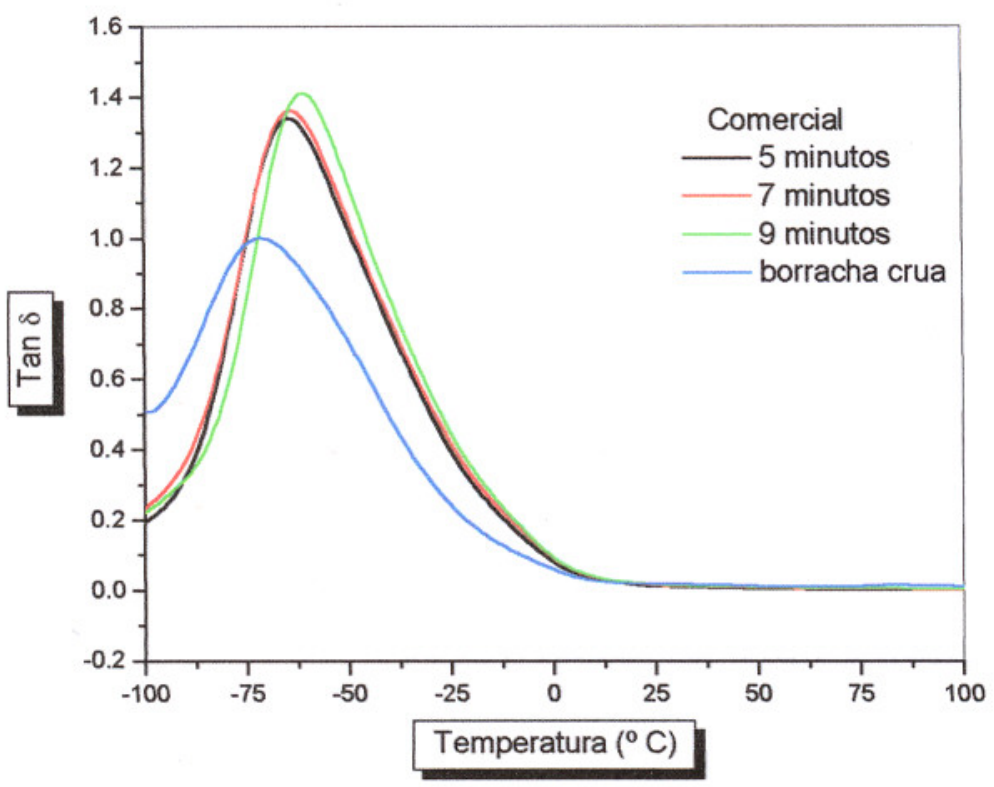

Figura 10. Curvas do fator amortecimento $(\tan \delta)$ versus temperatura da borracha comercial comparando-se os tempos de vulcanização $(5,7$ e 9 minutos) com a borracha crua.

Analisando-se a largura dos picos de $\tan \delta$ das amostras (Figuras 09 e 10 e Figuras 01 e 02 - Anexo A), pode-se afirmar que os compostos apresentaram picos mais estreitos do que a borracha crua, indicando homogeneidade, ou seja, boa dispersão das partículas de negro de fumo. $\mathrm{O}$ efeito do negro de fumo nas propriedades dinâmico-mecânicas é função principalmente do estado de dispersão, tanto em relação ao tamanho e número de partículas, quanto da distância de separação entre eles e a distribuição(59).

Pode-se afirmar com base nos dados obtidos neste estudo, que mesmo com tempos de vulcanização de 5, 7 e 9 minutos e com diferentes clones, o comportamento dos compostos não mudam significativamente em relação ao comportamento dinâmico-mecânico, e portanto todos os clones atendem aos 
requisitos de baixa temperatura de transição vítrea que são necessários para o uso de borracha para várias aplicações.

Materiais com alto amortecimento dissipam muito da energia que foi utilizada para deformá-lo na forma de calor. Nas Figuras 11 e 12 e Figuras 03 e 04 - Anexo A, estão ilustradas as curvas do log E' (módulo de armazenamento) versus temperatura. Como mencionado anteriormente os materiais poliméricos apresentam componentes elásticas e plásticas. O módulo de armazenamento é o módulo relativo à componente elástica. Na Figura 11, apresentamos o log do módulo de armazenamento ( $\left.E^{\prime}\right)$, versus a temperatura da borracha natural crua dos diferentes clones, da blenda e da borracha comercial do tipo GEB1. Observa-se na Figura 12 que a blenda e a borracha comercial apresentam um módulo maior que os demais sendo o tempo de vulcanização igual para todos (5 minutos).

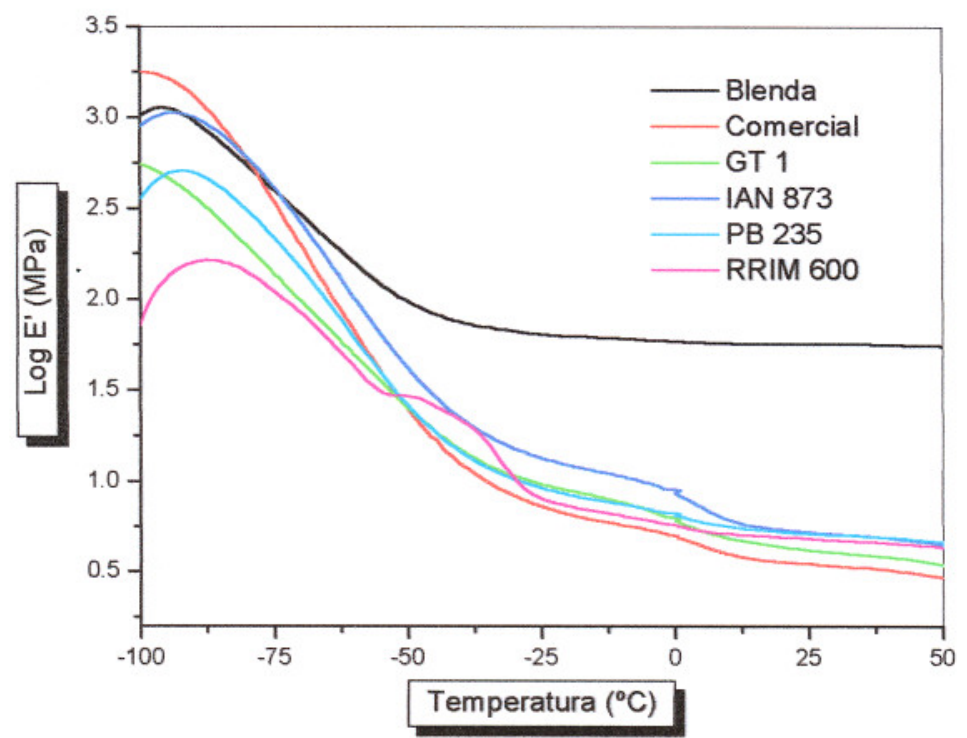

Figura 11. Curvas do módulo de armazenamento ( $\left.E^{\prime}\right)$ versus temperatura para as amostras de borracha natural crua. 
Através das análises do módulo de armazenamento observados nas Figuras 11, 12 e 13 e Figuras 03 e 04 - Anexo A, pode-se dizer que há uma pequena diferenças nos valores obtidos nos módulos para os compostos, isso já não é observado em relação as amostras de borracha natural crua, apresentam os valores de módulos bem abaixo dos valores dos compostos (Figura 13). $\mathrm{Na}$ análise da blenda crua verificamos que ela apresentou um maior valor para o módulo de armazenamento em relação aos clones, e esse comportamento continuou para os 3 tempos de vulcanização.

Comparando o mesmo composto (PB 235) mas com diferentes tempos de vulcanização (5, 7 e 9 minutos) com a borracha natural crua, observa-se que o composto vulcanizado a 7 minutos possui um maior, e o tempo 9 minutos 0 menor módulo, já a borracha natural crua apresentou um valor de módulo bem abaixo do encontrado para os compostos, como é mostrado na Figura 13. 


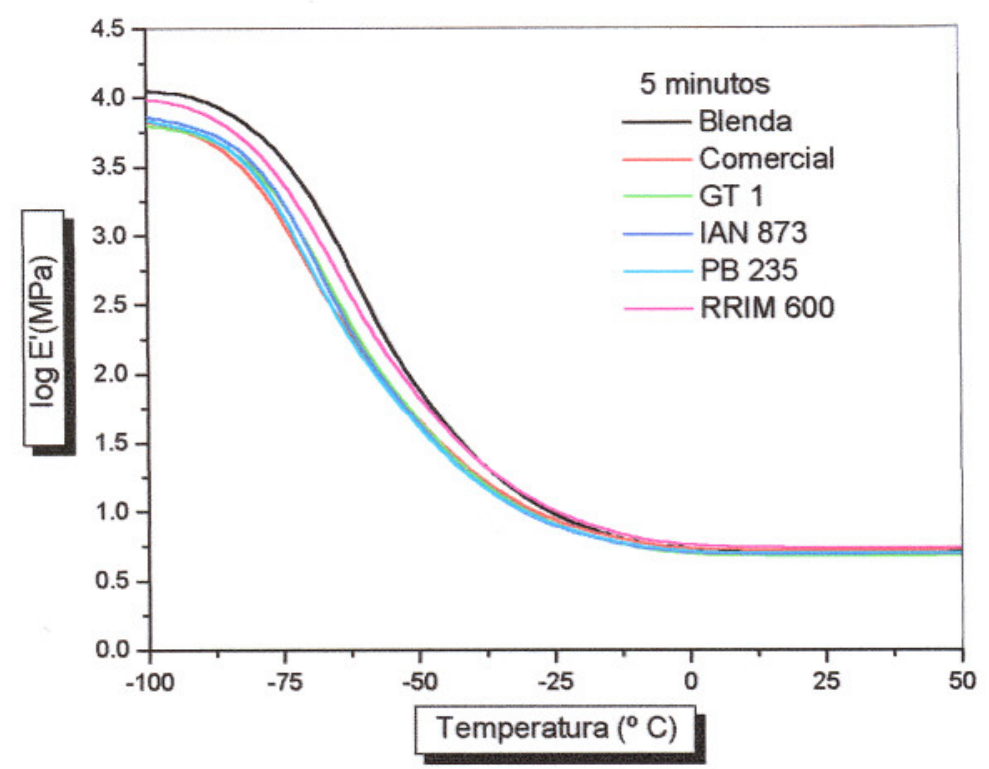

Figura 12. Curvas do módulo de armazenamento ( $\left.E^{\prime}\right)$ versus temperatura dos compostos: blenda, borracha comercial, GT 1, IAN 873, PB 235 e RRIM 600 com tempo de vulcanização de 5 minutos.

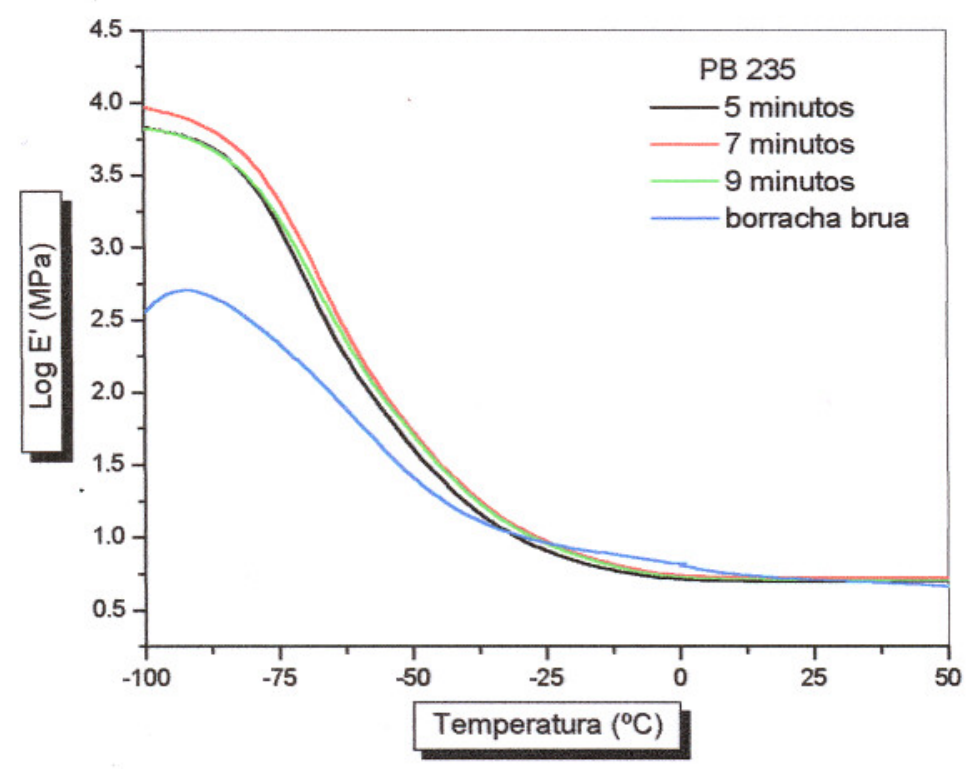

Figura 13. Curvas do log módulo de armazenamento ( $\left.E^{\prime}\right)$ versus temperatura do clone PB 235 comparando os tempos de vulcanização (5, 7 e 9 minutos) com a borracha natural crua. 
De maneira geral os resultados obtidos para o E', não apresentam uma variação constante entre os clones GT 1, IAN 873, PB 235 e RRIM 600, pois sabe-se que as propriedades da borracha natural crua variam com o tipo de clone e o período de coleta em que a borracha é obtida, mas de maneira geral após a vulcanização esta diferença praticamente desaparece.

\subsubsection{Calorimetria Diferencial de VarRedura (DSC)}

Na Figura 14 tem-se as curvas de DSC obtidas para as amostras de borracha natural crua. Os valores obtidos para a Tg estão listados na Tabela 7. $\mathrm{O}$ intervalo de variação é pequeno $\left(-62,0\right.$ a $\left.-63,2{ }^{\circ} \mathrm{C}\right)$. Estes valores são menores que os encontrados para os compostos vulcanizados (Tabela 08), devido a ausência de ligações cruzadas por enxofre.

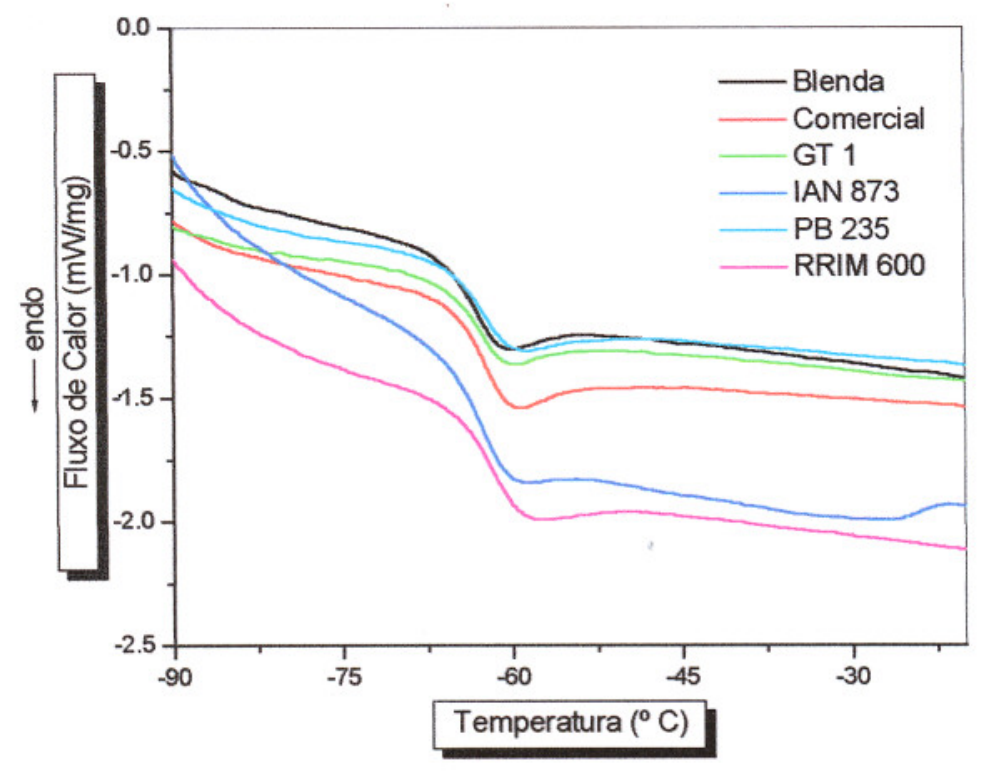

Figura 14. Curvas de DSC para as amostras de borracha natural crua. 


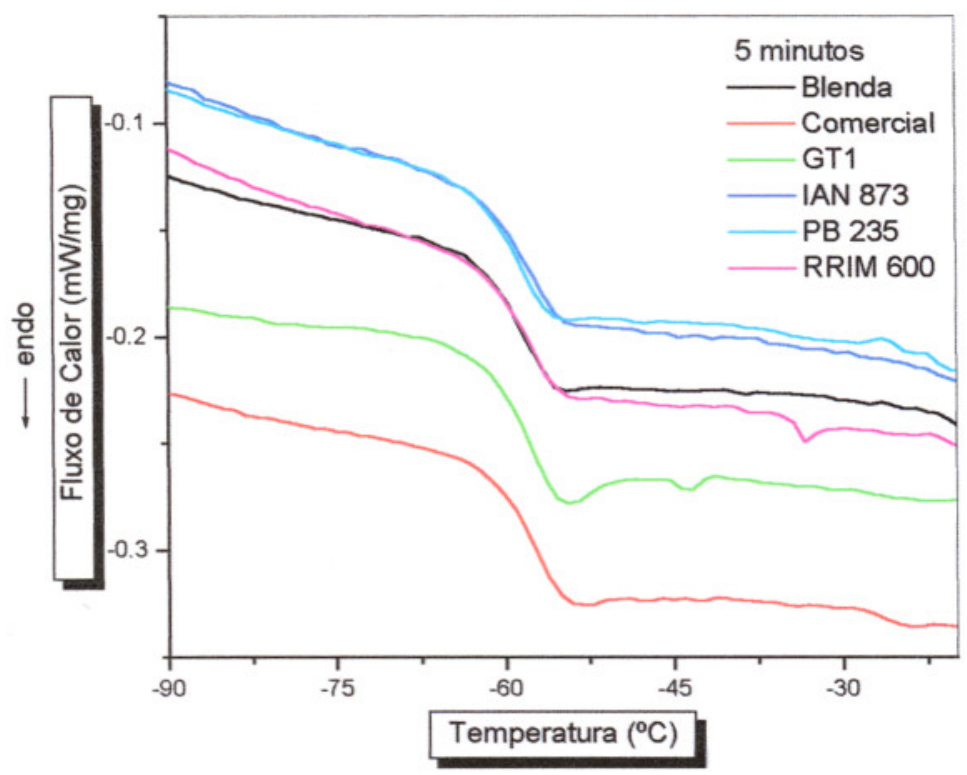

Figura 15. Curvas de DSC dos compostos: blenda, borracha comercial, GT 1, IAN 873, PB 235 e RRIM 600 com tempo de vulcanização de 5 minutos.

Analisando-se a Figura 15, observa-se que não houve mudanças significativas entre os diferentes clones para as borrachas vulcanizadas a 5 minutos, para os valores da $\mathrm{Tg}$ (Tabela 08). O mesmo tipo de comportamento foi obtido para os tempos de 7 e 9 minutos, Figuras 05 e 06 - Anexo A. $\mathrm{O}$ método utilizado para obtenção da Tg através da análise de DSC está ilustrado na Figura 16, onde.foi realizada a primeira derivada da curva. 


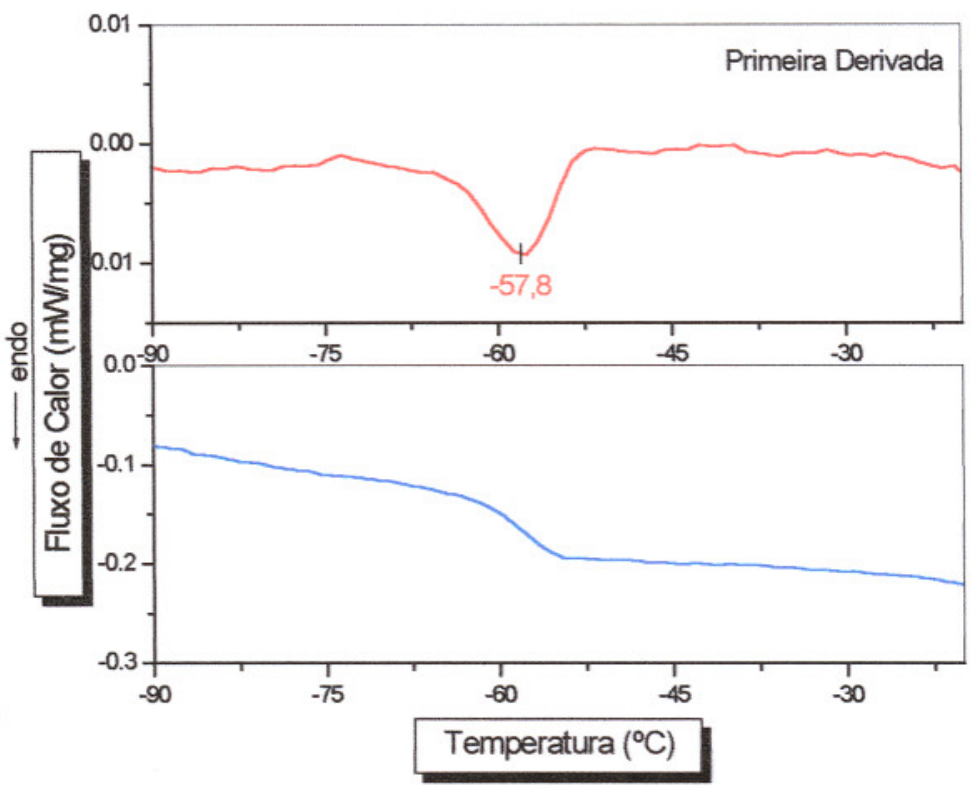

Figura 16. Curva de DSC do clone IAN 873, com tempo de vulcanização de 5 minutos com a primeira derivada - processo para obter o valor da $\mathrm{Tg}$.

Comparando-se as curvas obtidas pela análise de DSC para a borracha comercial com diferentes tempos de vulcanização de 5, 7 e 9 minutos (Figura 17), observa-se que não houve uma grande variação nos valores da $\mathrm{Tg}$, como mostrado na Tabela 08, em função do tempo de vulcanização. As amostras também foram analisados por DSC na faixa de 0 a $180^{\circ} \mathrm{C}$, porém não demonstraram nenhuma outra transição aparente nesta faixa de temperatura. 


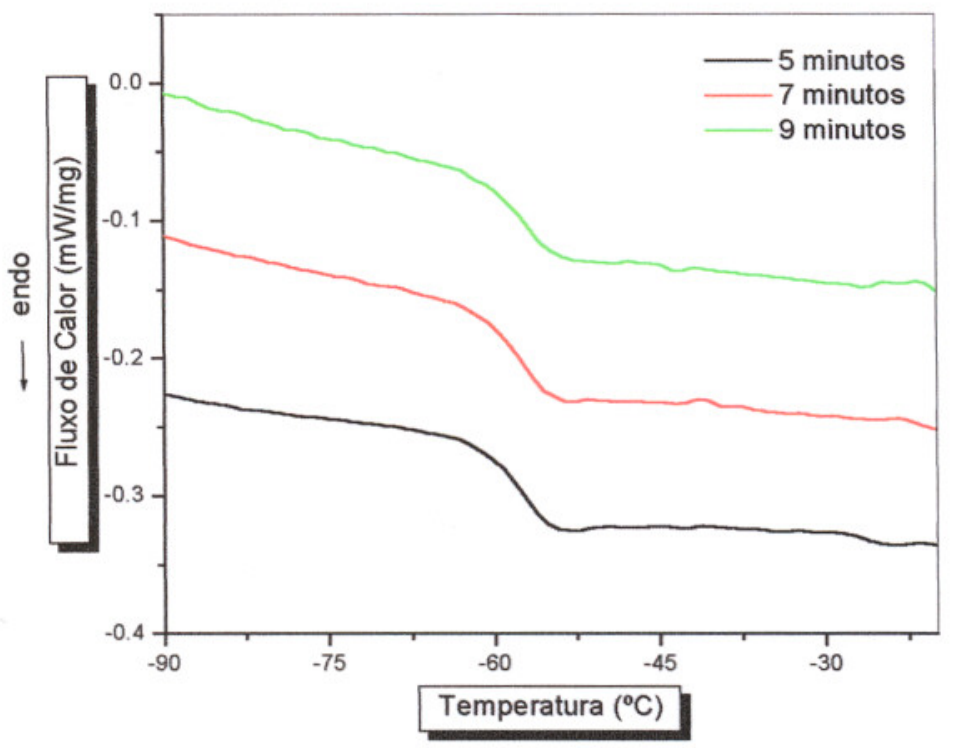

Figura 17. Curvas de DSC da borracha comercial comparando os tempos de vulcanização (5, 7 e 9 minutos).

\subsubsection{ANÁlise Termogravimétrica (TGA)}

A análise termogravimétrica foi realizada para avaliar a estabilidade térmica da borracha natural crua e dos compostos de borracha natural (Figuras 18 e 19). Através da análise da Figura 19, pode-se notar que as amostras com tempo de vulcanização de 5 minutos tiveram o mesmo comportamento, o que também ocorreu para os tempos de vulcanização de 7 e 9 minutos, Figuras 07 e 08 - Anexo A. 


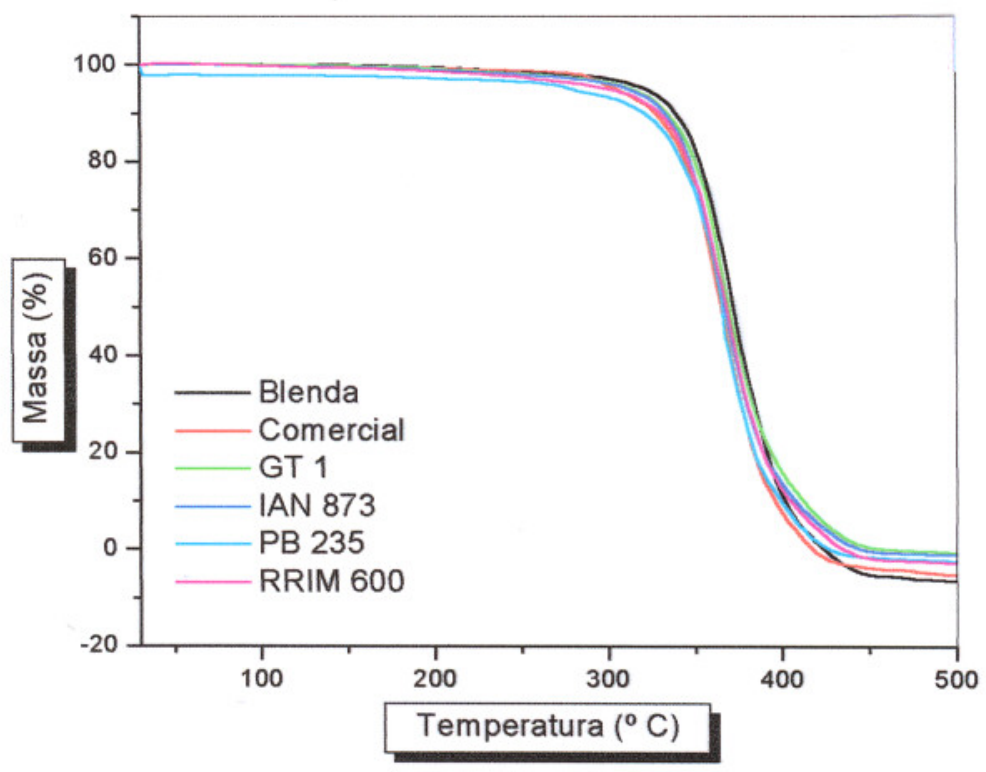

Figura 18. Curva de TGA das amostras de borracha natural crua.

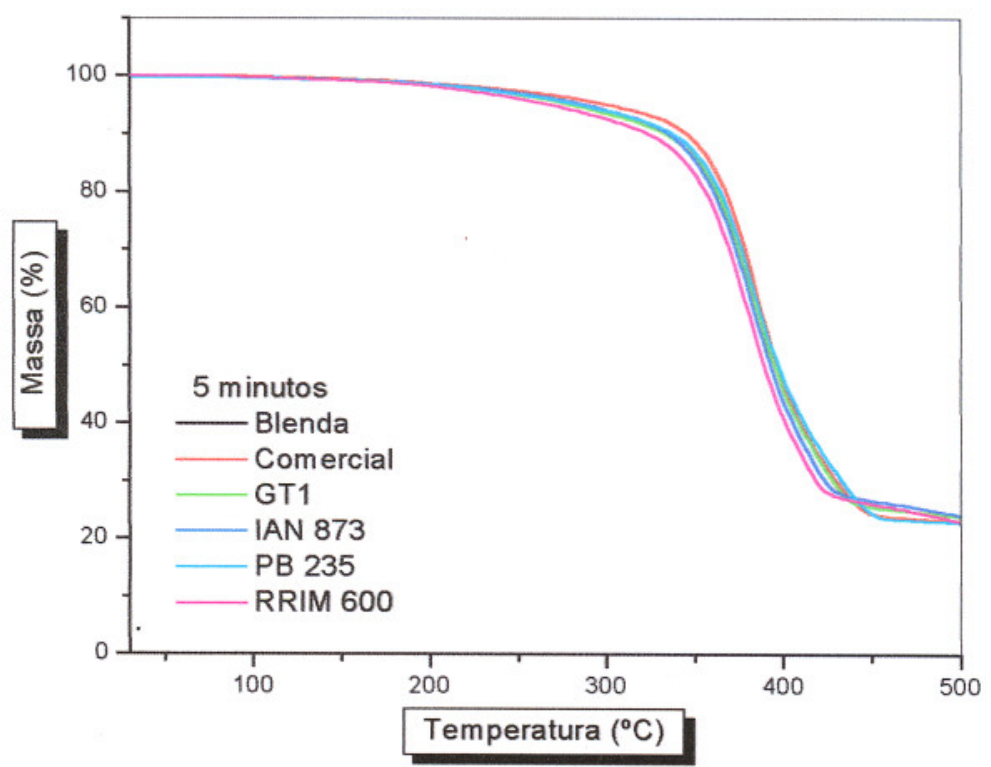

Figura 19. Curvas de TGA dos compostos: blenda, borracha comercial, GT 1 , IAN 873, PB 235 e RRIM 600 com tempo de vulcanização de 5 minutos.

$\mathrm{Na}$ Figura 20 realizou-se um aumento da região inicial de análise. Verifica-se que os compostos de borracha natural (NR) apresentam uma perda 
de massa de aproximadamente $2 \%$ até a temperatura de $228^{\circ} \mathrm{C}$, observandose que não houve eliminação de água ou outros extrativos. A perda de massa vai se acentuando e em torno de aproximadamente $300{ }^{\circ} \mathrm{C}$ começa a degradação estrutural da borracha natural, que perde cerca de $50 \%$ de massa até a temperatura de $360^{\circ} \mathrm{C}$.

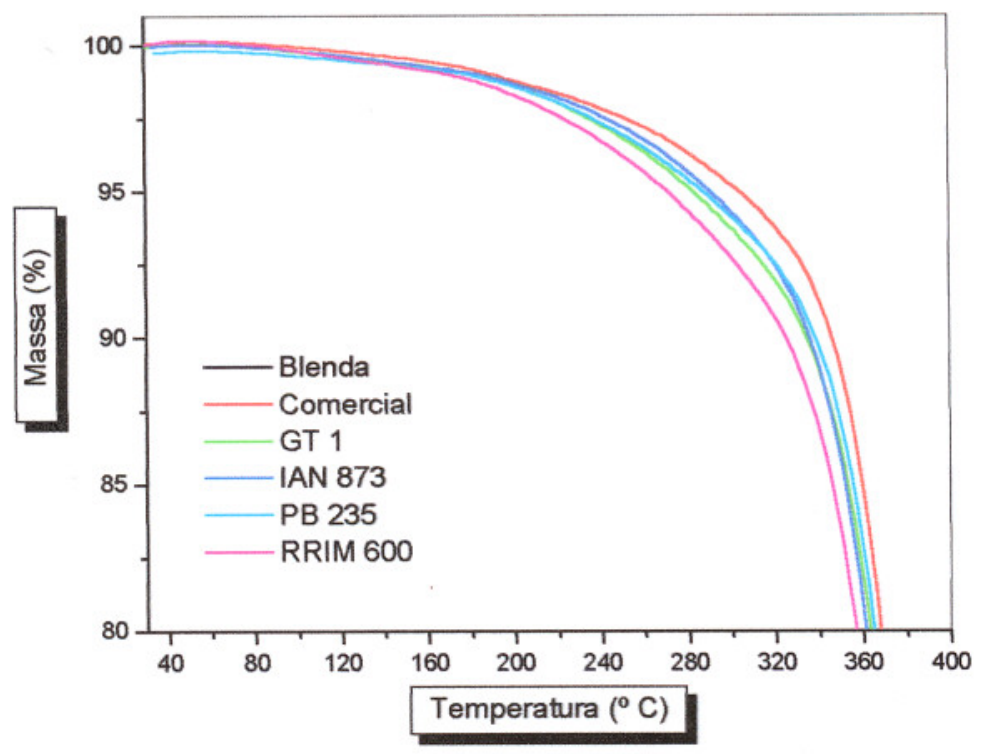

Figura 20. Curva de TGA dos compostos com tempo de vulcanização de 5 minutos, para uma melhor visualização da perda de massa.

Na Figura 21, observa-se que com diferentes tempos de vulcanização os clones possuem a mesma perda de massa, restando uma massa residual em torno de $20 \%$, ou seja, $30 \mathrm{phr}$ que é o negro de fumo adicionado para a composição dos compostos de borracha natural. 


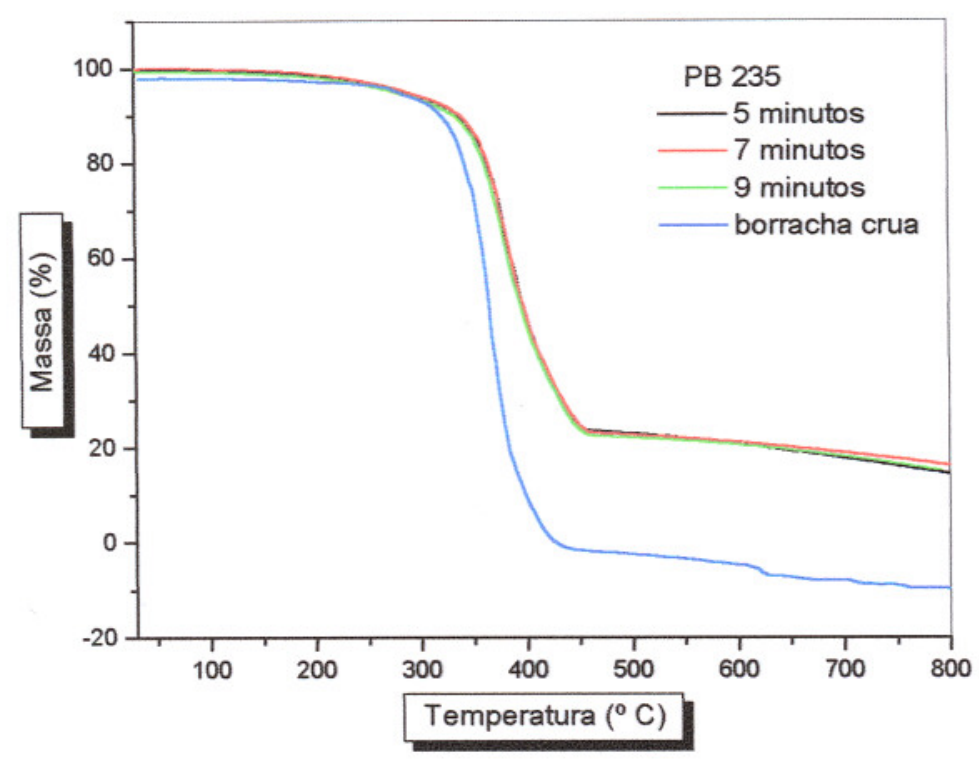

Figura 21. Curvas de DSC do clone PB 235 comparando os tempos de vulcanização de 5, 7 e 9 minutos com a borracha crua.

A amostra da borracha crua apresentou maior perda de massa (Figura 21), devido a ausência de aditivos (negro de fumo, enxofre, antioxidante), nas formulações, que ajudam na estabilização da mesma.

\subsection{INFRAVERMELHO (FTIR)}

As análises na região do infravermelho tiveram como objetivo a obtenção de espectros para caracterização do isômero cis-1,4-poliisopreno predominante na cadeia das amostras, e dentro do limite de sensibilidade do FT-IR não se observou isômeros trans-1,4. As Figuras 22 e 23 apresentam espectros na região do infravermelho dos clones GT 1, IAN 873, PB 235 e RRIM 600, da blenda e da borracha comercial. Na Tabela 9 estão relacionadas as principais bandas, com as correspondentes atribuições. 


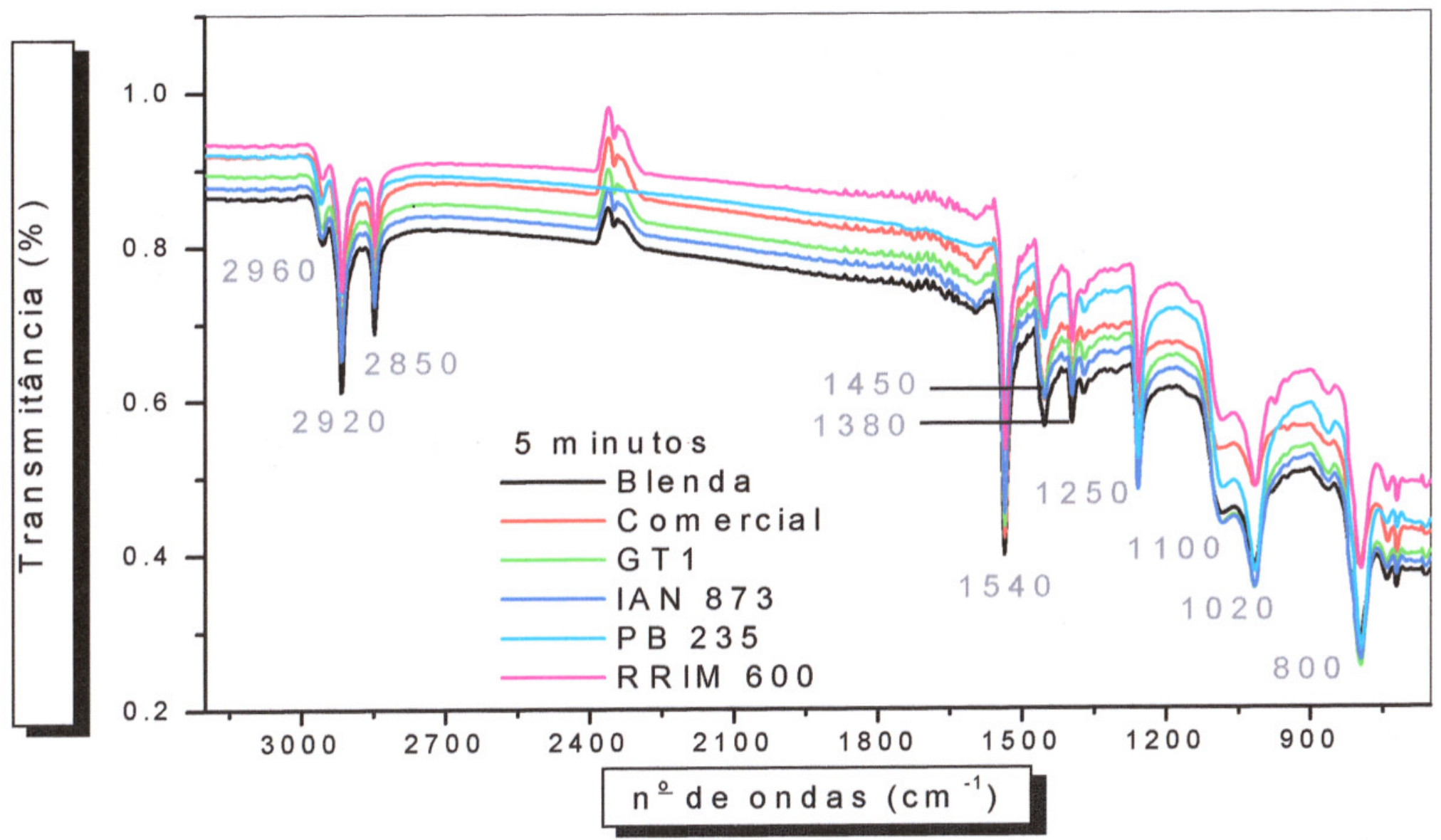

Figura 22. Curvas de FT-IR separados por regiões de absorção dos compostos: blenda, borracha comercial, GT 1, IAN 873, PB 235 e RRIM 600 com tempo de vulcanização de 5 minutos. 
Tabela 09. Principais bandas encontrada na literatura para o poli(cis-1,4isopreno) e suas atribuições ${ }^{(62,63)}$.

\section{Posição da Banda $\left(\mathrm{cm}^{-1}\right) \quad$ Atribuído a}

$\begin{array}{cc}\text { Em torno de } 3000 & \text { Estiramento da ligação C-H do carbono olefínico } \\ 2950 & \mathrm{C}-\mathrm{H} ;=\mathrm{C}-\mathrm{H} \text {; estiramento ligação } \mathrm{C}-\mathrm{H} \\ 2924 & \text { Estiramento assimétrico do grupo metila } \\ 2890 & \text { Estiramento simétrico do grupo metila } \\ 1600 & \mathrm{C}=\mathrm{C}-\mathrm{C}=\mathrm{C} \text {; estiramento ligação } \mathrm{C}=\mathrm{C} \\ 1490 & \text { Deformação angular } \mathrm{H}-\mathrm{C}-\mathrm{H} \\ 1420 & \text { Curvamento e deformação angular } \mathrm{H}-\mathrm{C}-\mathrm{H} \\ 920 & \text { Estiramentos ligações } \mathrm{R}_{1} \mathrm{CH}=\mathrm{CHR} \mathrm{R}_{2} \text { na forma trans } \\ 840 & \text { Flexão da ligação } \mathrm{C}-\mathrm{H} \text { em olefina trissubstiuída, } \\ & \text { típica do encadeamento cis-1,4 }\end{array}$

Em $2960 \mathrm{~cm}^{-1}$, temos uma banda de estiramento da ligação $\mathrm{C}-\mathrm{H}$ do carbono olefínico. Na região de 2920 e $2850 \mathrm{~cm}^{-1}$, encontramos o estiramento assimétrico e simétrico do grupo metila ${ }^{(62,63)}$.

$\mathrm{Na}$ região de 1450 e $1380 \mathrm{~cm}^{-1}$, encontramos deformação angular assimétrica e simétrica do grupo metila, na região de $1540 \mathrm{~cm}^{-1}$, observamos um estiramento da ligação $\mathrm{C}=\mathrm{C}$, e finalmente na região de $800 \mathrm{~cm}^{-1}$, atribuída a flexão da ligação C-H em olefina trissubstituída típica do encadeamento cis-1,4. A região entre 1315 e $870 \mathrm{~cm}^{-1}$, tem sido objeto de discussão. As bandas 1250 , 1100 e $1020 \mathrm{~cm}^{-1}$ são atribuídas respectivamente à deformação angular fora do 
lano e fora de fase do grupo metilênico, deformação axial da ligação $\mathrm{C}-\mathrm{CH}_{2}$ no plano $^{(62,63)}$

Nas Figuras 09 e 10 - Anexo A, temos os espectros dos compostos de borracha natural vulcanizados a 7 e 9 minutos respectivamente, apresentando as mesmas bandas para os diferentes compostos, não sendo observada nenhuma diferença significativa.

A Figura 23 apresenta espectros do composto de borracha natural do clone RRIM 600 com os 3 tempos de vulcanização (5, 7 e 9 minutos.) 


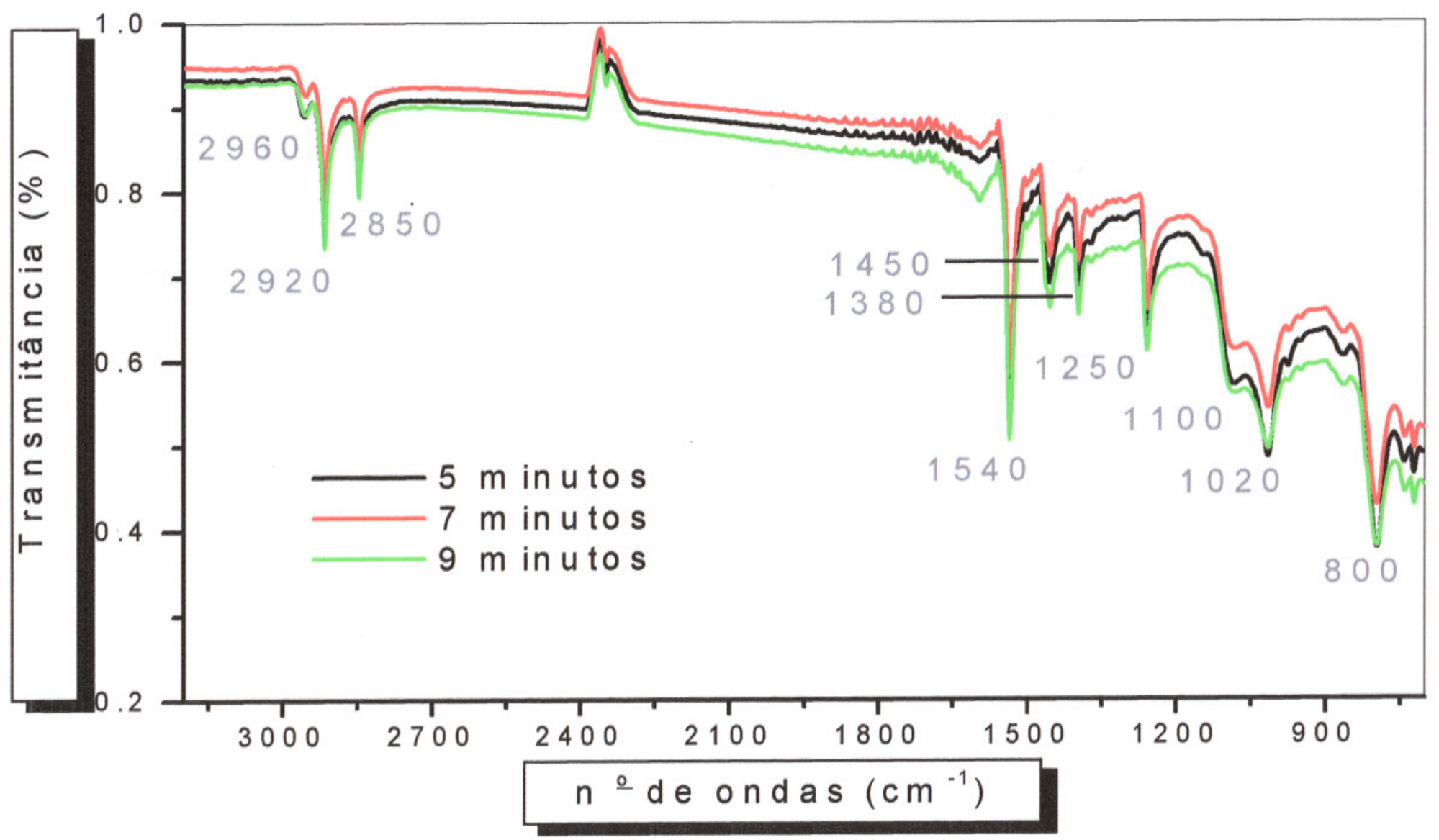

Figura 23. Curvas de FT-IR separados por regiões de absorção do clone RRIM 600 comparando os tempos de vulcanização $(5,7$ e 9 minutos) 


\subsection{Microscopia Eletrônica de VARREduRA (MEV)}

Este estudo tem por objetivo observar a dispersão do negro de fumo na matriz de borracha natural. Para o estudo do MEV, foram analisadas e comparadas as micrografias dos compostos dos clones GT 1, IAN 873, PB 235, RRIM 600, da blenda e da borracha comercial do tipo GEB 1. A análise foi realizada nas seções fraturadas das amostras quebradas dentro de nitrogênio líquido.

Analisando as micrografias apresentadas para os compostos da blenda (5 minutos), GT 1 (5, 7 e 9 minutos), nas Figuras 24, 25, 26 e 27 para o estudo da morfologia das amostras em relação ao tempo de vulcanização. Não há diferenças significativas relacionadas com o tempo. As partículas da carga (negro de fumo) estão bem distribuídos na matriz de NR.

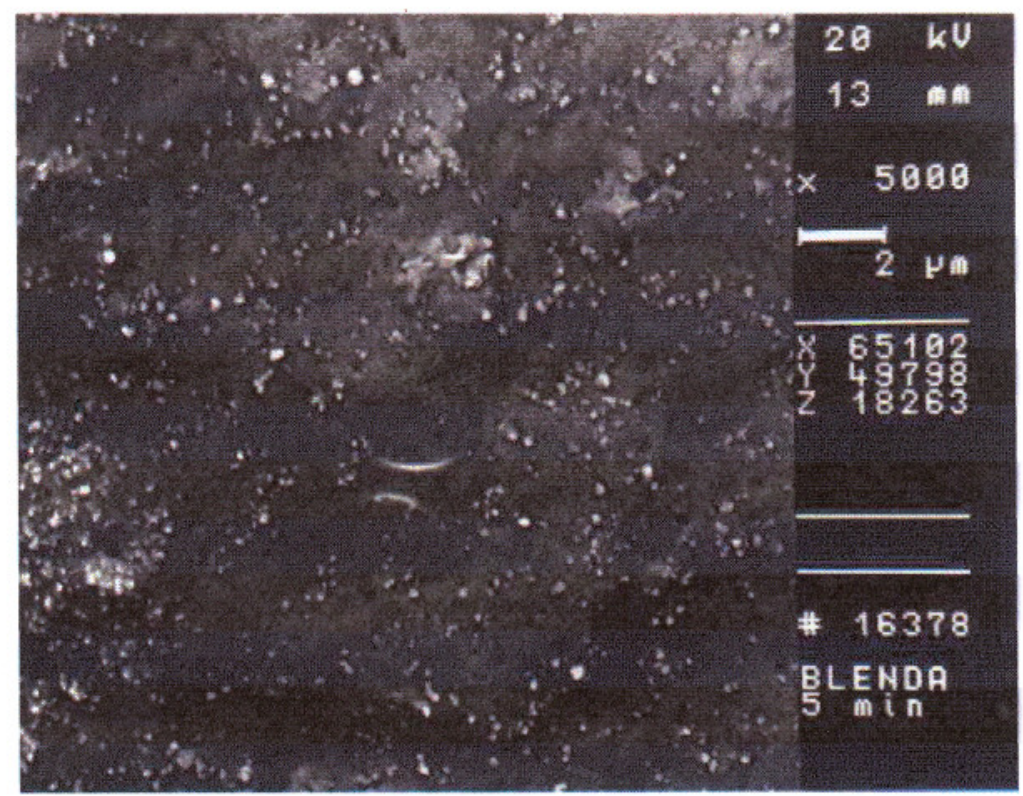

Figura 24. Fotografia obtida por MEV da seção fraturada em nitrogênio líquido da blenda, com vulcanização de 5 minutos. Ampliação de 5000x. 


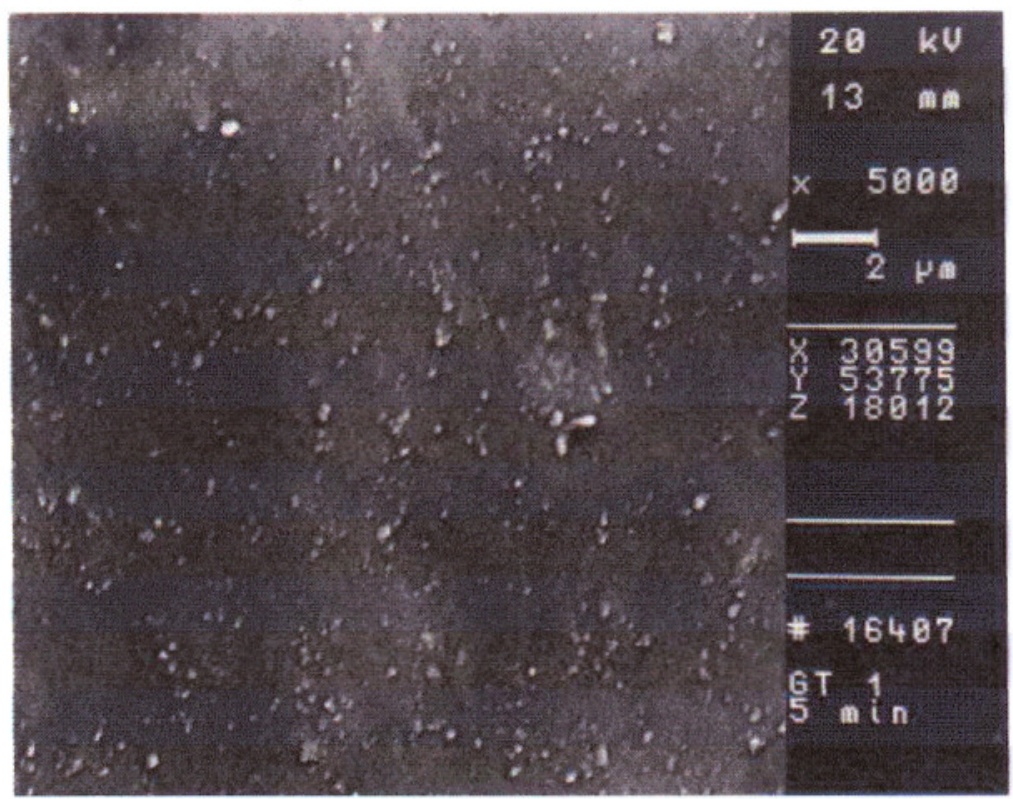

Figura 25. Fotografia obtida por MEV da seção fraturada em nitrogênio líquido do clone GT 1, com vulcanização de 5 minutos. Ampliação de 5000x.

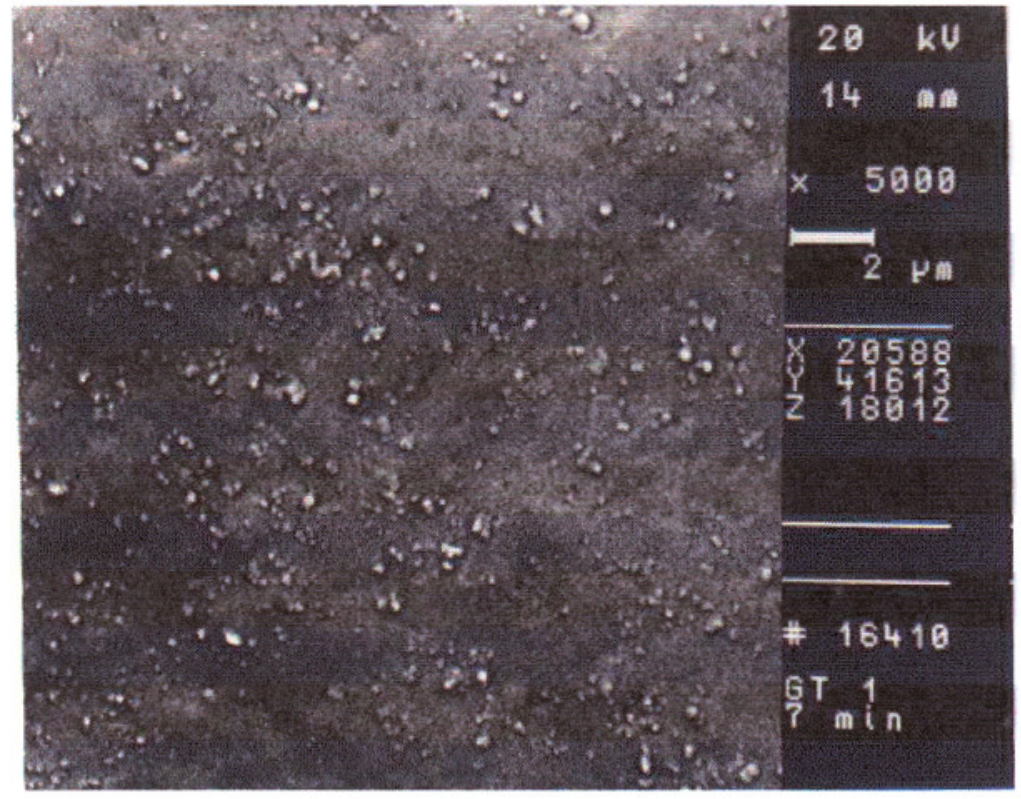

Figura 26. Fotografia obtida por MEV da seção fraturada em nitrogênio líquido do clone GT 1, com vulcanização de 7 minutos. Ampliação de 5000x. 


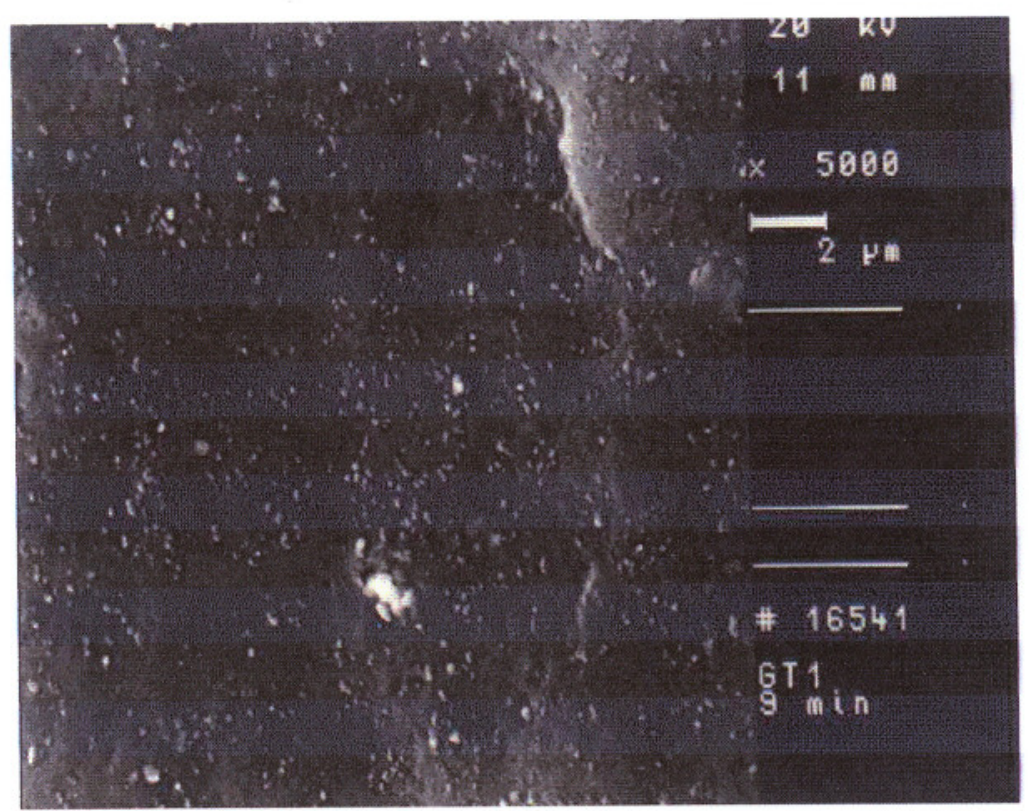

Figura 27. Fotografia obtida por MEV da seção fraturada em nitrogênio líquido do clone GT 1, com vulcanização de 9 minutos. Ampliação de 5000x.

As análises da superfície de fratura da blenda, dos clones e da borracha comercial, mostradas nas Figuras 28, 29 e 30 (A, B, C, D, E e F) demonstram que não há diferença morfológica significativa entre as amostras com diferentes clones. Observa-se que as partículas do negro de fumo estão bem distribuídos na matriz, devido as boas condições de processamento utilizado, os quais levaram a obtenção de um material uniforme, sem falhas e uma mistura homogênea dos componentes da formulação. Como foi observado nas curvas de DMTA, sendo que os picos mais estreitos obtidos para os compostos em relação as amostras de borracha natural crua demonstraram que tiveram uma boa dispersão da carga (negro de fumo). 

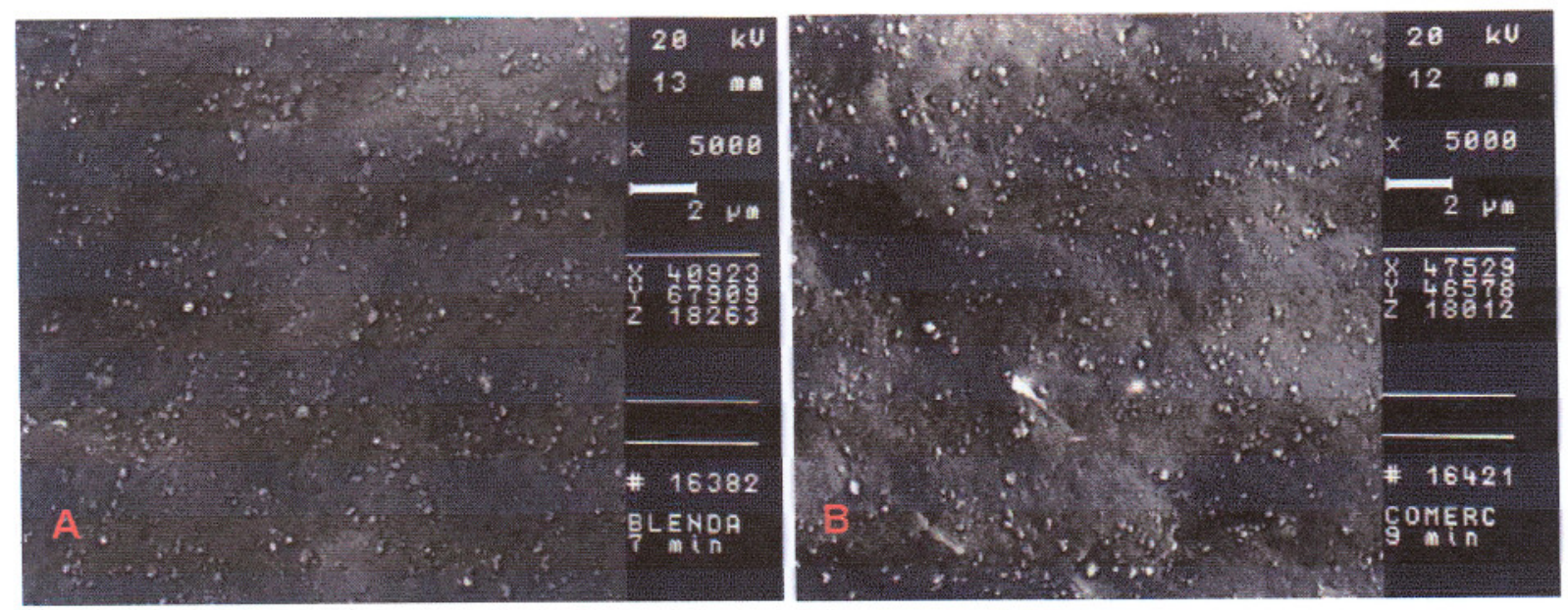

Figura 28. Fotografia obtida por MEV da seção fraturada em nitrogênio líquido. A - blenda (7 minutos) e B - Comercial ( 9 minutos). Ampliação de 5000x.
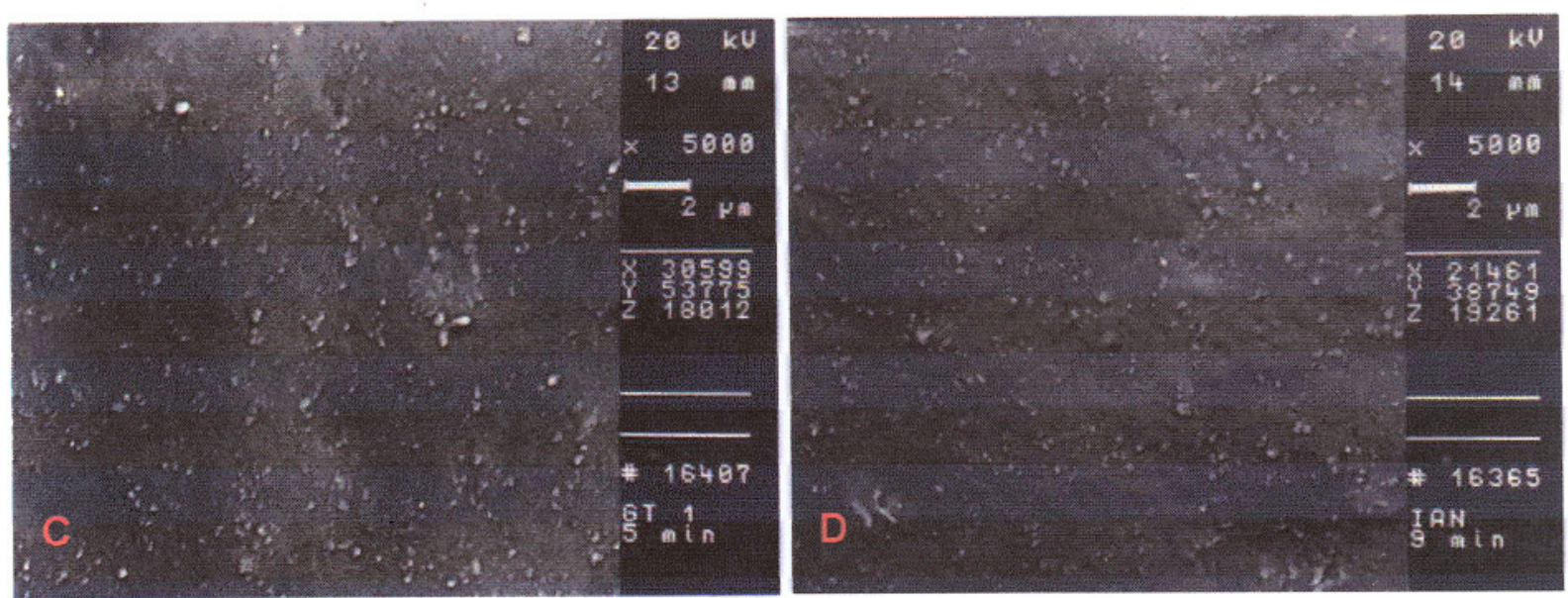

Figura 29. Fotografia obtida por MEV da seção fraturada em nitrogênio líquido. C - GT 1 (5 minutos) e D - IAN 873 (9 minutos). Ampliação de 5000x. 

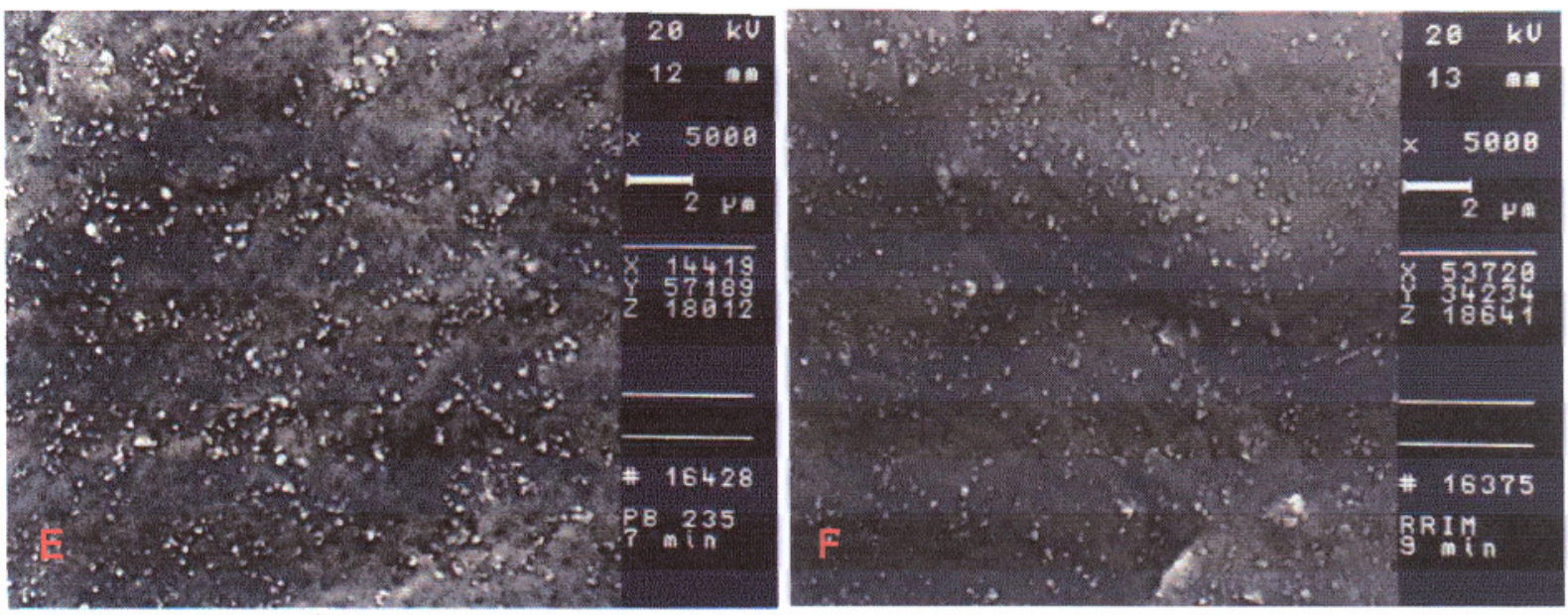

Figura 30. Fotografia obtida por MEV da seção fraturada em nitrogênio líquido. E - PB 235 (7 minutos) e F - RRIM 600 (9 minutos). Ampliação de 5000x.

\subsection{ENSAIOS DE TRAÇÃo}

Os valores encontrados na literatura ${ }^{(59)}$ para tensão é de 17 a $25 \mathrm{MPa}$ e para o módulo de 1,3 MPa, estes valores foram encontrados para as borrachas vulcanizadas somente com enxofre. Para a análise comparativa dos resultados de tração, deformação e módulo foi encontrada a média calculada, de acordo com a Equação (1), os valores encontram-se nas Tabelas 10, 11 e 12.

As Figuras 31, 32 e 33 apresentam as curvas de tensão versus deformação dos compostos vulcanizados a 5, 7 e 9 minutos, respectivamente. Os compostos dos clones GT 1 e IAN 873 apresentaram resultados de tensão, deformação e módulo menores que a média calculada é abaixo do valor encontrado na literatura. O composto do clone RRIM 600 foi o que apresentou a melhor resistência a tração. A borracha comercial (GEB 1) apresentou valores acima da média teórica e dentro dos valores da literatura. A média 
teórica obtida (17,3 MPa) está dentro do intervalo de variação citado na literatura (17-25 MPa).

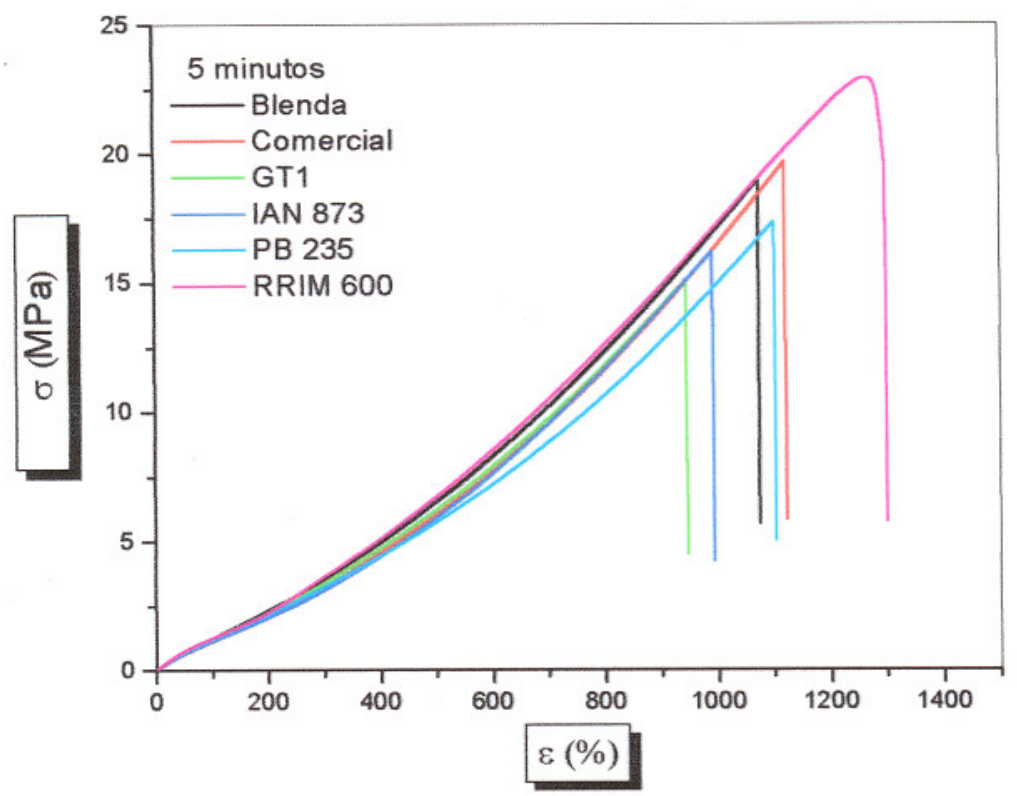

Figura 31. Gráfico tensão versus deformação para os compostos de borracha natural vulcanizados a 5 minutos.

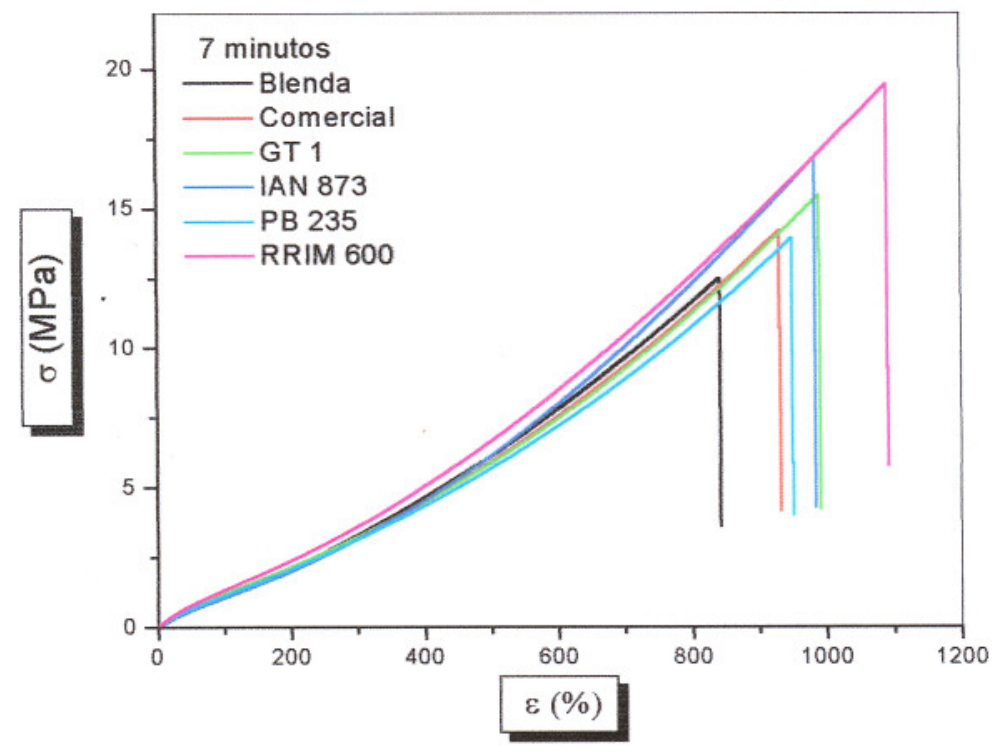

Figura 32. Gráfico tensão versus deformação para os compostos de borracha natural vulcanizados a 7 minutos. 


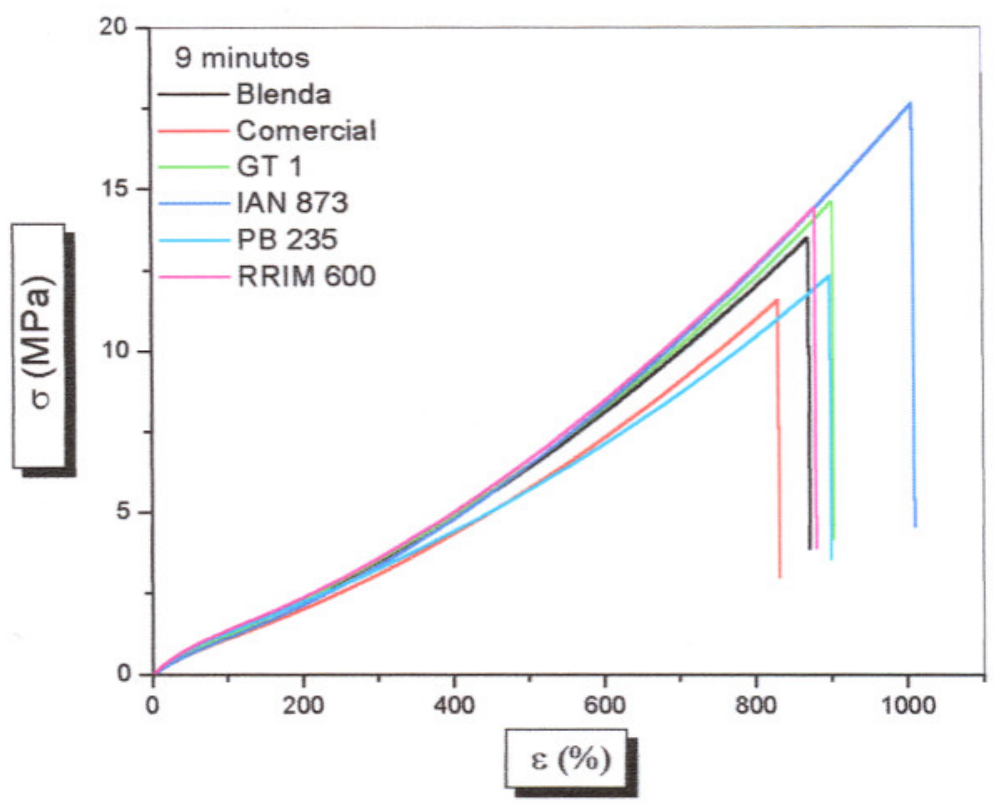

Figura 33. Gráfico tensão versus deformação para os compostos de borracha natural vulcanizados a 9 minutos.

Tabela 10. Valores de tensão de ruptura $(\sigma)$, deformação $(\varepsilon)$ e módulo $(E)$ para as amostras de borracha natural com tempo de vulcanização de 5 minutos.

\begin{tabular}{lccc}
\hline \multicolumn{1}{c}{ Amostra } & $\sigma(\mathrm{MPa})$ & $\varepsilon(\%)$ & $\mathrm{E}(\mathrm{MPa})$ \\
\hline Blenda & $18,2 \pm 2$ & $1067,0 \pm 91$ & $2,4 \pm 0,1$ \\
Comercial & $20,1 \pm 2$ & $1147,3 \pm 58$ & $2,6 \pm 0,1$ \\
GT 1 & $13,7 \pm 6$ & $863,3 \pm 252$ & $2,1 \pm 0,4$ \\
IAN 873 & $16,3 \pm 2$ & $994,5 \pm 77$ & $2,4 \pm 0,1$ \\
PB 235 & $17,3 \pm 2$ & $1094,7 \pm 82$ & $2,3 \pm 0,1$ \\
RRIM 600 & $21,8 \pm 2$ & $1223,5 \pm 131$ & $2,6 \pm 0,4$ \\
$\overline{\mathrm{x}}_{\text {calculado }}$ & 17,3 & 1044,0 & 2,4 \\
\hline
\end{tabular}


Tabela 11. Valores de tensão de ruptura $(\sigma)$, deformação $(\varepsilon)$ e módulo (E) para as amostras de borracha natural com tempo de vulcanização de 7 minutos.

\begin{tabular}{lccc}
\hline \multicolumn{1}{c}{ Amostra } & $\sigma(\mathrm{MPa})$ & $\boldsymbol{\varepsilon}(\%)$ & $\mathrm{E}(\mathrm{MPa})$ \\
\hline Blenda & $13,6 \pm 3$ & $888,1 \pm 156$ & $2,1 \pm 0,2$ \\
Comercial & $15,8 \pm 3$ & $988,8 \pm 128$ & $2,3 \pm 0,2$ \\
GT 1 & $15,8 \pm 2$ & $977,5 \pm 91$ & $2,3 \pm 0,1$ \\
IAN 873 & $14,7 \pm 4$ & $902,1 \pm 178$ & $2,3 \pm 0,3$ \\
PB 235 & $14,2 \pm 5$ & $942,3 \pm 278$ & $2,1 \pm 0,4$ \\
RRIM 600 & $20,7 \pm 2$ & $1130,3 \pm 89$ & $2,5 \pm 0,1$ \\
\multicolumn{1}{c}{ calculado } & 16,4 & 988,1 & 2,3 \\
\hline
\end{tabular}

Tabela 12. Valores de tensão de ruptura $(\sigma)$, deformação $(\varepsilon)$ e módulo $(E)$ para as amostras de borracha natural com tempo de vulcanização de 9 minutos.

\begin{tabular}{lccc}
\hline \multicolumn{1}{c}{ Amostra } & $\sigma(\mathrm{MPa})$ & $\mathbf{\varepsilon}(\%)$ & $\mathrm{E}(\mathrm{MPa})$ \\
\hline Blenda & $11,7 \pm 3$ & $772,7 \pm 116$ & $2,0 \pm 0,2$ \\
Comercial & $11,6 \pm 6$ & $795,6 \pm 323$ & $1,9 \pm 0,5$ \\
GT 1 & $13,4 \pm 7$ & $851,5 \pm 311$ & $2,1 \pm 0,5$ \\
IAN 873 & $17,0 \pm 4$ & $972,1 \pm 147$ & $2,5 \pm 0,2$ \\
PB 235 & $12,8 \pm 2$ & $901,8 \pm 104$ & $2,0 \pm 0,2$ \\
RRIM 600 & $14,6 \pm 5$ & $868,0 \pm 221$ & $2,3 \pm 0,4$ \\
\multicolumn{1}{c}{ calculado } & 14,5 & 898,4 & 2,2 \\
\hline
\end{tabular}

Nos resultados dos ensaios de tração com o tempo de vulcanizaçăo de 7 minutos a blenda, apresentou valores inferiores a média calculada (Figura $32 \mathrm{e}$ Tabela 11). O composto do clone RRIM 600 apresentou os melhores resultados de tensão, deformação e módulo, resultando valores dentro do intervalo de variação encontrado na literatura. A média calculada para os 
compostos vulcanizados a 7 minutos (16,4 MPa)está abaixo da encontrada na literatura (17 a $25 \mathrm{MPa})$.

Os resultados de tensão, deformação e módulo dos compostos vulcanizados a 9 minutos (Figura 33 e Tabela 12), mostraram que o composto do clone IAN 873 obteve os melhores resultados do ensaio de tração. A média teórica resultante deste ensaio $(14,5 \mathrm{MPa})$, ficou bem abaixo do intervalo de variação encontrado na literatura (17 a $25 \mathrm{MPa}$ ). Só composto do clone IAN 873 está de acordo com os resultados da literatura para os ensaios de tensão.

O módulo de Young está diretamente relacionado com a rigidez do polímero, ou seja, quanto maior for seu valor, maior será sua rigidez. Os resultados obtidos para o módulo para o 3 tempos de vulcanização $(5,7$ e 9 minutos), ficaram acima de $2 \mathrm{MPa}$, superiores ao valor encontrado na literatura $(1,3 \mathrm{MPa})^{(59)}$.O clone RRIM 600 foi o que apresentou o melhor resultado da análise mecânica, sendo um dos clones mais produtivos.

Com o aumento do tempo de vulcanização houve um decréscimo nos valores de tensão de ruptura, deformação e módulo para a maioria das amostras dos compostos de borracha natural. Em temperaturas elevadas, neste caso $145^{\circ} \mathrm{C}$ utilizada para a vulcanização dos compostos, ocorrem reações competitivas de cisão de cadeia e formação de ligações cruzadas, que podem influenciar neste comportamento, devido a junção de tempo e temperatura, como pode ser visto na Figura 34 para o clone RRIM 600, para os 3 tempos de vulcanização. 


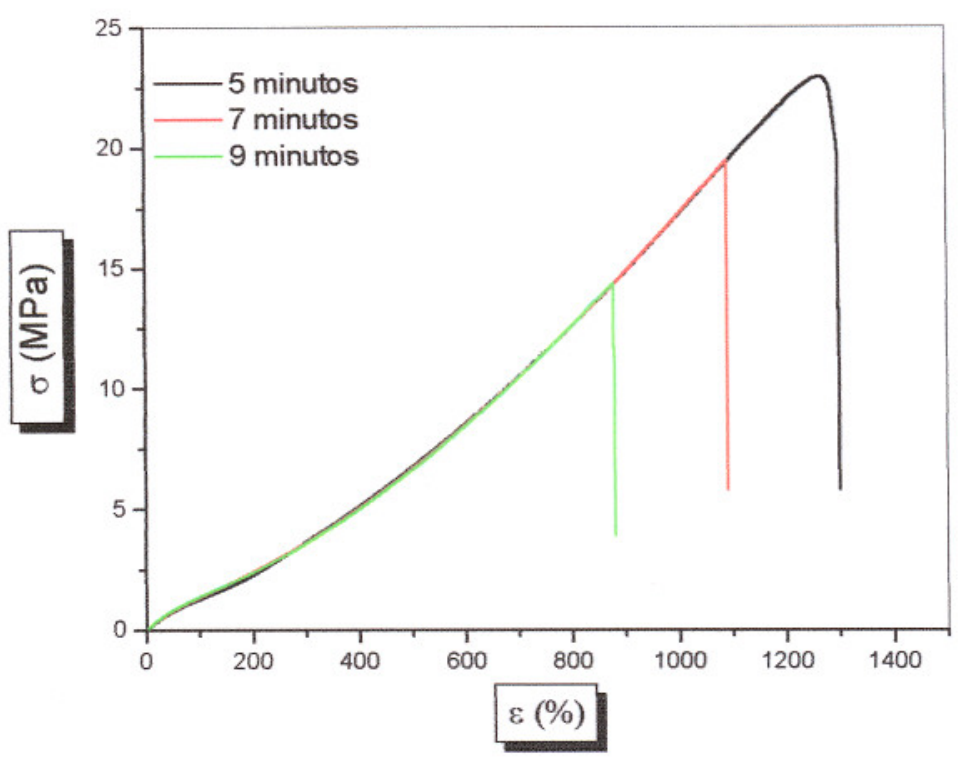

Figura 34. Gráfico tensão versus deformação para os compostos do RRIM 600 para os tempos vulcanização de 5, 7 e 9 minutos.

Verifica-se através dos resultados obtidos que o negro de fumo, atua como reforço para a matriz de NR, melhorando suas propriedades mecânicas como módulo elástico e a resistência a tração, sem no entanto perder significativamente sua elongação. A mobilidade molecular do polímero diminui com o aumento do conteúdo de carga (negro de fumo), devido a formação de ligações físicas entre as partículas da carga e as cadeias do polímero. Consequentemente a elongação na ruptura diminui com o aumento das $\operatorname{cargas}^{(30)}$.

De acordo com SOARES et al ${ }^{(64)}$ os valores de tensão na ruptura não são influenciados pelo sistema de vulcanização MBTS e TMTD que são empregados como aceleradores no processo de vulcanização, os autores comprovaram que o uso de aceleradores não influencia nos ensaios mecânicos, 
a combinação de 2 aceleradores é sinérgica, ou seja, um acelerador ativa o outro, e melhores velocidades de formação de ligações cruzadas são obtidas.

\subsection{DUREZA}

A dureza é proporcional a quantidade de ligações cruzadas formadas durante o processo de vulcanização, sendo assim, é diretamente afetada pela quantidade de enxofre e NF presente. Neste estudo foi usado 2,5 e 30 phr de enxofre e negro de fumo respectivamente ${ }^{(39)}$.

A Tabela 13 apresenta os resultados obtidos em relação a dureza. É claramente observado que o tempo de vulcanização não tem efeito significativo na dureza dos compostos. Obteve-se valores em torno de 60, para os compostos independentemente do tipo de clone ou tempo de vulcanização.

Tabela 13. Média e desvio padrão da dureza Shore A para os compostos de borracha natural

\begin{tabular}{lcccccc}
\hline & \multicolumn{2}{c}{5 minutos } & \multicolumn{2}{c}{7 minutos } & \multicolumn{2}{c}{9 minutos } \\
Amostras & Dureza & $\mathbf{s}$ & Dureza & $\mathbf{s}$ & Dureza & s \\
\hline Blenda & 60 & 0,55 & 61 & 0,55 & 61 & 0,45 \\
Comercial & 59 & 0,30 & 60 & 0,45 & 60 & 0,45 \\
GT 1 & 61 & 0,55 & 61 & 0,55 & 62 & 0,55 \\
IAN 873 & 61 & 0,55 & 61 & 0,84 & 61 & 0,37 \\
PB 235 & 61 & 0,45 & 62 & 0 & 62 & 0,55 \\
RRIM 600 & 61 & 0,55 & 62 & 0,89 & 62 & 0,45 \\
\hline
\end{tabular}




\subsection{DISCUSSÃO FINAL DOS RESULTADOS}

Baseados nos resultados obtidos, os clones GT 1, IAN 873, PB 235 e RRIM 600 podem ser utilizados nas indústrias de artefatos de borracha separadamente, devido aos resultados obtidos nas análises térmicas e mecânicas realizadas, sendo que as árvores dos clones PB 235 e RRIM 600 são as mais produtoras de borracha segundo trabalho realizado na Embrapa que analisou os clones GT 1, IAN 873, PB 235 e RRIM 600, na Estação Experimental do IAC em Votuporanga, como podemos observar na Figura 35.

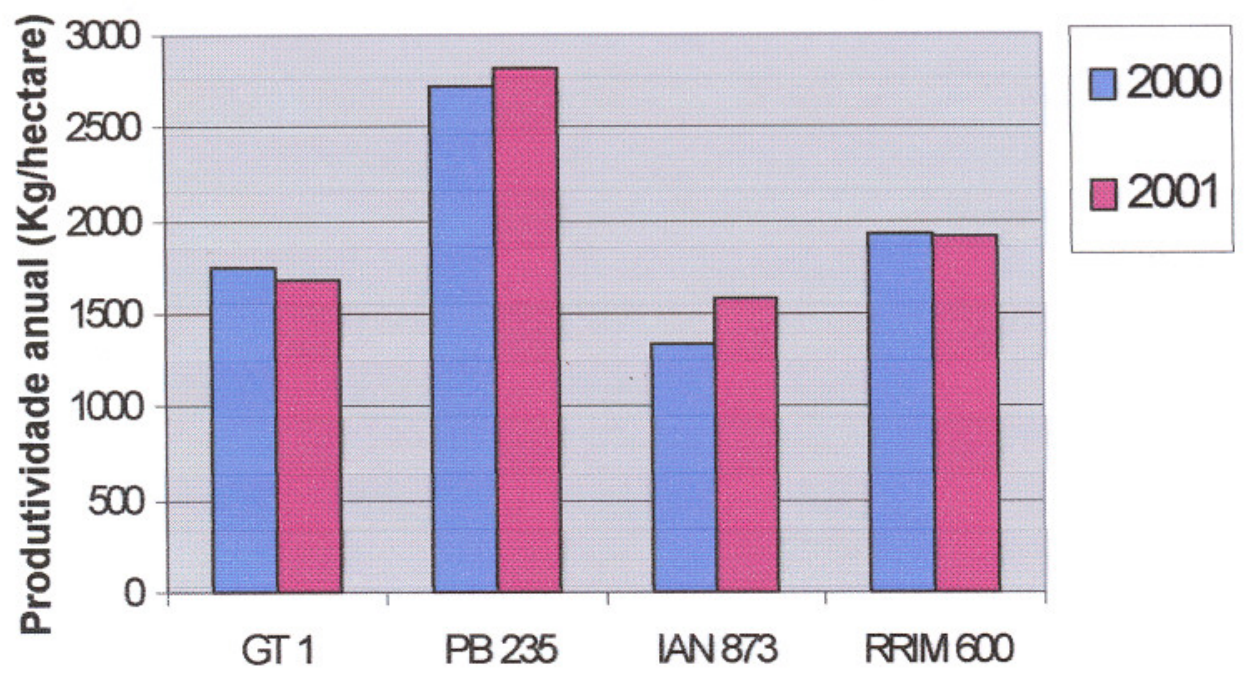

Figura 35: Produção dos clones da região de Votuporanga( ${ }^{(32)}$. 


\section{ConCLUSÕES}

Os resultados dos ensaios padrões (teor de nitrogênio, teor de cinzas, extrato acetônico, plasticidade, viscosidade e PRI), apresentaram algumas variações nos valores entre as amostras de borracha natural crua (blenda, borracha comercial, GT 1, IAN 873, PB 235 e RRIM 600), mas após o processamento e vulcanização os compostos apresentaram resultados muito próximos. Com a composição utilizada, obteve-se um composto adequado para ser usado na fabricação de artefatos que devam ter boa resistência à tração. Desta forma, todos os compostos apresentaram resultados satisfatórios, ficando dentro dos padrões de qualidade exigidos na literatura.

$\mathrm{Na}$ análise térmica os valores obtidos para os compostos para a temperatura de transição vítrea $(\mathrm{Tg})$ pelas análises de DSC e DMTA, foram na faixa de $-57,1^{\circ} \mathrm{C}$ a $-58,8^{\circ} \mathrm{C}$ e $-56,5$ a $-66,4$, respectivamente. Considerando que a $\mathrm{Tg}$ encontrada para a borracha natural crua foi aproximadamente $-62^{\circ} \mathrm{C}$ através da técnica de DSC e variando $-92,5^{\circ} \mathrm{C}$ a $-66,0^{\circ} \mathrm{C}$ através do DMTA. A técnica de DMTA é muito mais sensivel do que a técnica de DSC, pois verifica as deformações (tração, cisalhamento e compressão). A blenda crua apresentou um valor bem inferior aos encontrados para as outras amostras, devido a maior mastigação sofrida para uma completa homogeneização, ocorrendo a quebra das macromoléculas, consequentemente diminuindo o valor da $\mathrm{Tg}$. Depois da vulcanização houve um aumento da $\mathrm{Tg}$, devido ao fato que a borracha ser reforçada pelo negro de fumo (NF) e também pela estrutura 
reticulada, obtida pela ligação cruzada com enxofre. A largura dos picos de tan $\delta$ obtidos para os diferentes compostos, na análise de DMTA foram mais estreitos que os encontrados para as amostras de borracha natural crua, indicando boa homogeneidade e dispersão das partículas do negro de fumo na matriz elastomérica.

Não há perda de massa significativa na faixa da temperatura ambiente até cerca de $228^{\circ} \mathrm{C}$, indicando que não ocorreu perda de massa relacionada à eliminação de água ou outros extrativos, conforme se observa pela análise de TGA. Em torno de $300{ }^{\circ} \mathrm{C}$ começa a degradação estrutural da borracha natural, que perde cerca de $50 \%$ da massa até a temperatura de $360^{\circ} \mathrm{C}$.

Todos os compostos de NR apresentaram uma morfologia compacta e homogênea com boa dispersão do negro de fumo, conforme analisadas nas fotomicrografias das amostras criofraturadas e confirmada pelos picos estreitos obtidos pelas análises de DMTA.

O clone RRIM 600 foi o que apresentou os melhores resultados da análise mecânica, sendo um dos clones com maior produtividade de borracha seca. A borracha comercial apresentou nos tempos de vulcanização de 7 e 9 minutos valores de resistência mecânica, dentro da média, bem próximo dos valores encontrados para as amostras dos compostos.

Para os ensaios de dureza, obteve-se valores em torno de 60 para todos os compostos, indiferente do tipo de clone ou tempo de vulcanização, estando, possivelmente, somente relacionado com a quantidade de enxofre e de negro 
de fumo que atua como um reforço para a matriz de NR, melhorando suas propriedades mecânicas como resistência a tração e dureza.

Todos os compostos de borracha apresentaram as mesmas bandas de absorção nas análises de infravermelho, características do poli(cis-1,4isopreno), não apresentando nenhuma alteração entre os clones e tratamentos estudados 


\section{SUGESTÕES PARA TRABALHOS FUTUROS}

- Caracterização das borrachas pelas técnicas de FT-IR, EPR, RMN e MEV/EDX, para obter uma correlação entre as propriedades e a estrutura do borracha natural e a seleção de clones com melhor desempenho;

- Caracterização do látex e da borracha natural dos clones comerciais GT 1, IAN 873, PB 235 e RRIM 600 e comparação com os novos clones da série IAC de maior produtividade (IAC 40, IAC, 56, IAC 300, IAC 301, IAC 302, IAC 303, IAC 306 e IAC 307) por ensaios padröes (conteúdo de borracha seca, plasticidade Wallace, Viscosidade Mooney, teor de cinzas, extrato acetônico e teor de nitrogênio) e pelas análises térmicas (DSC, TGA e DMTA) e mecânicas (ensaios de tração);

- Formulação e processamento do couro vegetal com os clones de melhores propriedades, avaliação do desempenho mecânico e térmico do couro vegetal por calorimetria diferencial de varredura (DSC), análise termogravimétrica (TGA), ensaios de tração, análise térmica-dinâmicomecânica (DMTA), resistência ao rasgamento, teste de envelhecimento e degradação e avaliação morfológica por microscopia eletrônica de varredura (MEV). 


\section{REFERÊNCIAS BIBLIOGRÁFICAS}

1) Gonçalves, P.S. Cadeia produtiva da borracha natural para o Estado de São Paulo. p.50, 1997.

2) IRSG Rubber Statistical Bulletin, v.56, n.8, 2002.

3) GONÇALVES, P.S. Razões pelas quais devemos evitar o plantio monoclonal de seringueira. Disponivel em: <http://apabor.org.br/artigos/index.html> Acesso em: 20 jan. 2003.

4) RUBBER RESEARCH INSTITUTE OF MALAYSIA Revisions to standard Malaysian rubber scheme, SMR Bulletin 9, 1979.

5) WISNIEWSKI, R. Látex e borracha. Belém, Ministério da Educação e Cultura, Faculdade de Ciências Agrárias do Pará, Serviço de Documentação e Informação, 1983.

6)Encyclopedia of Polymer Science and Engineering, Willy Interscience Publication, EUA, 1987, v.8.

7) Gonçalves, P.S. - Desenvolvimento de tecnologias para a cultura da seringueira no Estado de São Paulo - Campinas, IAC, (Projeto 07.0.95.001, SEP), 1994.

8) VAZQUEZ CORTEZ, J. A evolução da cultura da seringueira no Estado de São Paulo-Brasil. In: GONÇALVES, P. de S.; BENESI, J. F. C. (eds.) CICLO DE PALESTRAS SOBRE A HEVEICULTURA PAULISTA, 1, 1998. Barretos. Anais. Barretos: SAAIAPABOR, 1999, p.61-92.

9) MORENO, R. M. B. Caracterização do látex e da borracha natural de clones da região de Matão/SP. São Carlos, 1998. 65p. Dissertação (Mestrado) Departamento de Engenharia de Materiais, Universidade Federal de São Carlos.

10) JACOB, J. L.; PRÉVÔT, J.C.; LACOTE, R.; GOHET, E.; CLÉMENT, A.; d'AUZAC, J. Typologie clonale du fonctionnement des laticifères chez Hevea brasiliensis Plantations. Recherche, Developpement, v.Janvier-Fevrier, p.54-68 1998. 
11) Arope, A B.; Nor A B.M.; Hua, T.P. Rubber Owners' Manual. Rubber Res. Inst. Malaysia. Kuala Lumpur, Chap. 5, 1983.

12) BENESI, J. F. C. Borracha Natural. In.. GONÇALVES, P. de S.; BENESI, J. F. C. (eds.) CICLO DE PALESTRAS SOBRE A HEVEICULTURA PAULISTA, 1 , 1998. Anais. Barretos, SAA/APABOR, 1999. p.92-100.

13) DAVIS W. Borracha Sintética é Inviável. Estado de S. Paulo, São Paulo, 17 agosto 1997. Economia.

14) ENCYCLOPEDIA OF POLYMER SCIENCE AND ENGINEERING. Willy Interscience Publication. EUA, 1987. v.8.

15) RIPPEL, M., GALEMBECK, F. Heterogeneidade do Látex de Borracha Natural: Caracterização das Partículas de Borracha por TEM/ELSI. In. REUNIÃO ANUAL DA SOCIEDADE BRASILEIRA DE QUÍMICA, 23, Poços de Caldas, 2000. Anais. Poços de Caldas, Sociedade Brasileira de Química, 2000.

16) MAFFEI, F. J. H., GENOVA, J., RAMOS, M.B., MASSAKAZU, O. Apontamentos sobre a Borracha e sua Tecnologia, IPT, São Paulo, 1950.

17) WEBSTER, C.C. and PAARDEKOOPER, E.C. The botany of the rubber tree In: Rubber C. C. Webster and W. J. Baulkwill, ed. Longman Scientific \& Technical, Longman Group UK Limited, Longman House, Burnt Mill, Harlow, Essex CM20 2JE, England, 1989. p.614.

18) HWEE, E. A.; TANAKA, Y. Structure of natural rubber. Trends in Polymer Science. 1993. v.3, p.493-513.

19) SANTOS, M. A. Desenvolvimento de compósitos condutores elétricos de borracha natural com composto condutivo. São Carlos, 1999. 71p. Dissertação (Mestrado) - Departamento de Engenharia de Materiais, Universidade Federal de São Carlos.

20) ESAH, Y. Clonal characterisation of latex and rubber properties Journal Natural Rubber Research, v.5, n.1, p.52-80, 1990. 
21) SUBRAMANIAM, A. Molecular weight and other properties of natural rubber: A study of clonal variation In: INTERNATIONAL RUBBER CONFERENCE, 1 , 1975, Kuala Lumpur, Proceedings Kuala Lumpur: Rubber Research Institute of Malaysia, 1975, p.41-49.

22) FERREIRA, M., MORENO, R. B.; GONÇALVES, P. S.; MATTOSO, L. H. C. Evaluation of Natural Rubber from Clones of Hevea brasiliensis. Rubber Chemistry and Technology, USA, v.75, n.1, p.171-177, 2002.

23)PINHEIRO, E.G., Modelos Numéricos Aplicados à Vulcanização de Pneus. São Paulo, 2001. 125p. Dissertação (Mestrado) -Departamento de Engenharia Mecânica, Escola Politécnica da Universidade de São Paulo.

24) SMITH, W.F. Princípios de Ciência e Engenharia de Materiais. 3.ed., 892p.

25) Wisniewski, A. Extrativismo Vegetal. v.1. Belém, 1978.

26) FERREIRA, M. Caracterização do Látex e da Borracha Natural de Seringais de Presidente Prudente/SP. São Carlos, 1999. 80p. Dissertação (Mestrado) Instituto de Química de São Carlos, Universidade de São Paulo.

27) COSTA, H.M., VISCONTE, L.Y., NUNES, R.C.R., FURTADO, C.R.G. Aspectos Históricos da Vulcanização. Polímeros, Ciência e Tecnologia, v.12, n.2, p.125-129, 2003.

28) SERRES, E., LACROTTE, R., PRÉVOT, J.C., CLEMENT, A, COMMERE, J. and JACOB, J.L. Metabolic aspects of latex regeneration in situ for three Hevea clones. Indian Journal of Natural Rubber Research, v.7, n.2, p.72-88, 1994.

29) JACOB, J.L.; PREVOT, J.C.; ESCHBACH, J.M.; LACROTTE, R.; SERRES, E.; VIDAL, A. Latex flow, cellular regeneration and yield of Hevea brasiliensis . Influence of hormonal stimulation. In: Proceedings of the International Congress of Plant Physiology, New Delhi, India, February 15-20, 1988.

30) VISCONTE, L.Y., MARTINS, A.F., NUNES, R.C.R. e tal. Misturas NR/SBR: modos de preparação e propriedades. Polímeros, Ciência e Tecnologia, v.11, n.2, p.76-81, 2001

31) LE ROUX, Y.; EHABE, E.; SAINTE-BEUVE, J.; NKENGAFAC, J.; NKENG, J.; NGOLEMASANGO, F.; GOBINA, S. Seasonal and clonal variations in the 
latex and raw rubber of Hevea brasiliensis. Journal of Rubber Research, v.3, n. 3, p.142-156, 2000.

32) MORENO, R. M. B. Avaliação e monitoramento das propriedades do látex e da borracha natural de clones de seringueira recomendados para o plantio no planalto do Estado de São Paulo. São Carlos, 2002. 130p. Tese (Doutorado) Departamento de Engenharia de Materiais, Universidade Federal de São Carlos.

33) JAYASURIYA, M. M.; MITHRANANDA, S. Y.; RATNAYAKE, U.; SIRIWARDENA， S.; KUMARA， G.; LIYANAGE, R.; KURUPU, C.; WEJESEKARA, M. Effects of drying conditions on the technological properties of sheet natural rubber. Journal of Rubber Research, v.3, n.3, p.185-192, 2000. 34)ESCHBACH, J.M., ROUSSEL, D., VAN DE SYPE, H., JACOB, J.L., D'AUZAC, J. Relationships Between Yield and Clonal Physiological Characteristics of Latex from Hevea brasiliensis. Phisiology Végétale, v.22, n.3, p.295-304, 1984.

35) OLIVEIRA, M.G., SOARES, B.G. Influência do Sistema de Vulcanização nas Propriedades da Mistura NBR/EPDM. Polímeros, Ciência e Tecnologia, v.12, n.1, p.11-19, 2002.

36) SOMBATSOMPOP, N., Dynamic Mechanical Properties of Ground Flexible Polyurethane Foam Particles and Carbon-Black-Filled Rubber Vulcanisates. Polym.-Plast. Technol. Eng., v.37, n.1, p.1-18, 1998.

37) SAE-OUI, P., RAKDEE, C., THANMATHORN, P. Use of Rice Husk Ash as Filler in Natural Rubber Vulcanizates: In Comparison with Other Commercial Fillers. Journal of Applied Polymer Science, v.83, p.2485-2493, 2002.

38) COSTA, H.M., VISCONTE, L.L.Y., NUNES, R.C.R. Cinética de Vulcanização de Composições de Borracha Natural com Incorporação de Cinza de Casca de Arroz. Polímeros, Ciência e Tecnologia, v.12, n.2, p.102-106, 2003. 
39) BRÜCK, D., DORMAGEN, S. D. Einfluss von Metallkomplexen auf die Alterung von Elastomeren. Kutschuk Gummi Kunststoffe, v.47, n.10, p.744-747, 1994

40)FAGUNDES, E., PIEROZAN, N.J., SOUZA, A.A. Influência de Parâmetros de Mistura em Misturador Aberto. Revista Borracha Atual, São Paulo, ed. 42, p.38-39, 2002.

41)ESCÓCIO, V.A., MARTINS, A.F., VISCONTE, L.Y., NUNES, R.C.R. Influência da Mica nas Propriedades Mecânicas e Dinâmico-Mecânicas de Composições de Borracha Natural. Polímeros, Ciência e Tecnologia, v.12, n.2, p. 130-134, 2003.

42) ASSOCIAÇÃO BRASILEIRA DE NORMAS TÉCNICAS, NBR 11597/1996 Natural Rubber. Rio de Janeiro, 1996.

43) Chun, C.K.; Tupy, J and Resing, W.L. - Changes in organo-mineral composition and respiratory activity of Hevea latex associated with intensive tapping. J. Rubber Res. Inst Malaysia, v.21, n.4, p. 484-493, 1969.

44) SANTOS, M. A.; MATTOSO, L.H.C. Compósitos de Borracha Natural com Compostos Condutivos à Base de Negro de Fumo e Polímero Condutor. Polímeros, Ciência e Tecnologia, v.11, n.3, p.126-134, 2001

45) GRIZON, E.C. Desenvolvimento de Formulações de Borracha. Instituto Gaúcho de Aperfeiçoamento Profissional, Porto Alegre, 1988.

46) HWEE, E. A.; TANAKA, Y. Structure of natural rubber. Trends in Polymer Science, v.3, p.493-513, 1993.

47) RUBBER RESEARCH INSTITUTE OF MALAYSIA Revisions to standard malaysian rubber scheme, SMR Bulletin 9, 1979.

48) ESAH, Y. Clonal characterisation of latex and rubber properties. Journal of Natural Rubber Research, v.5, n.1, p. 52-80, 1990.

49) BURFIELD, D.R.; GAN, S.N. Nonoxidative crosslinking reactions in natural rubber. I: Determination of crosslinking groups. Journal of Polymer Science: Polymer. Chemistry Edition, v. 13, p.2725-2744, 1975. 
50) NA-RANONG, N., de LIVONNIÉRE, H. and JACOB, J.L. Natural rubber: doubts about the PRI Plantations, recherche, development, Mars-April, 1995.

51) NAIR, S. Dependence of bulk viscosities (Mooney and Wallace) on molecular parameters of natural rubber. Journal of Rubber Research Institute of Malaysia, v.23, n.1, p.76-81, 1970.

52) SEKARAN, N. Characterisation of natural rubber for greater consistency. Rubber World, v.198, n.4, p.27-30, 1988.

53) SAMBHI, M. S. An analysis of the plasticity retention index of the standard Malaysian rubber scheme. Journal of Natural Rubber Research, v.4, n.2, p.133140, 1989.

54) Burger, K.; Smith, H.P. - The natural rubber market. Review, analysis, politics and outlook. Cambridge, Woodhead Publishing Limited, 279p., 1997.

55) YIP, E.; SUBRAMANIAM, A. Characterization of variability in properties of clonal latex concentrates and rubbers. Journal of Rubber Research Institute of Malaysia, v.32, n.1, p.347-368, 1985.

56) CANEVAROLO JR., S.V. Análise Dinâmico-Mecânica Para Sistemas Poliméricos - Parte 1- O Amortecimento $(\tan \delta)$. ABPol, maio 1991, p.36-40, 1991.

57) PLEPIS, A.M.G. Caracterização Térmica de Polímeros por DSC. São Carlos, 1991. 100p. Monografia (qualificação doutorado) - Instituto de Física e Química de São Carlos, Universidade de São Paulo.

58) MANO, E.B., MENDES, L.C. Introdução a Polímeros. 2.ed. São Paulo, Edgard Blücher, 1999.

59) Polymer Handbook. 2.ed. John Wiley and Sous,

60)SIRCAR, A.K., GALASKA, M.L., CHARTOFF, R.P., Glass Transition of Elastomers Using Thermal Analysis Techniques. Rubber Chemistry and Technology, v.72, p.513-552, 1998.

61) MARTINS, A.F., NAPOLITANO, B.A., VISCONTE, L.L.Y., NUNES, R.C.R., Propriedades Mecânicas e Dinâmico-Mecânicas de Composições de 
Policloropreno com Negro de Fumo. Polímeros, Ciência e Tecnologia, v.12, n.3, p.147-152, 2002.

62) RÚVOLO FILHO, A. Físico-Quimica de Filmes de Borracha Clorada. São Carlos, 1986. 300p. Tese (Doutorado) - Instituto de Física e Química de São Carlos, Universidade de São Paulo.

63) MARINHO, J.R.D. Microestrutura de cis-poliisopreno de Látices Naturais. Rio de Janeiro, 1992. 170p. Tese (Doutorado) - Instituto de Macromeléculas, Universidade Federal do Rio de Janeiro.

64) OLIVEIRA, M.G., SOARES, B.G. Influência dos Sistema de Vulcanização nas Propriedades da Mistura NBR/EPDM. Polímeros, Ciência e Tecnologia, v.12, n.1, p.11-19, 2002. 